\title{
Ecological Screening Values for Surface Water, Sediment, and
} Soil

by

G. P. Friday

Westinghouse Savannah River Company

Savannah River Site

Aiken, South Carolina 29808

DOE Contract No. DE-AC09-96SR18500

This paper was prepared in connection with work done under the above contract number with the U.S.

Department of Energy. By acceptance of this paper, the publisher and/or recipient acknowledges the U. S. Government's right to retain a nonexclusive, royalty-free license in and to any copyright covering this paper, along with the right to reproduce and to authorize others to reproduce all or part of the copyrighted paper. 


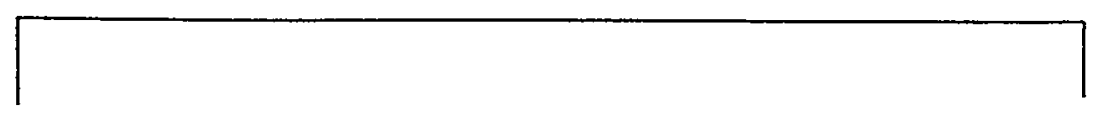

\section{DISCLAIMER}

This report was prepared as an account of work sponsored by an agency of the United States Government. Neither the United States Government nor any agency thereof, nor any of their employees, makes any warranty, express or implied, or assumes any legal liability or responsibility for the accuracy, completeness, or usefulness of any information, apparatus, product, or process disclosed, or represents that its use would not infringe privately owned rights. Reference herein to any specific commercial product, process, or service by trade name, trademark, manufacturer, or otherwise does not necessarily constitute or imply its endorsement, recommendation, or favoring by the United States Government or any agency thereof. The views and opinions of authors expressed herein do not necessarily state or reflect those of the United States Government or any agency thereof.

This report has been reproduced directly from the best available copy.

Available to DOE and DOE contractors from the Office of Scientific and Technical Information, P.O. Box 62, Oak Ridge, TN 37831; prices available from (615) 576-8401.

Available to the public from the National Technical Information Service, U.S. Department of Commerce; 5285 Port Royal Road, Springfield, VA 22161.

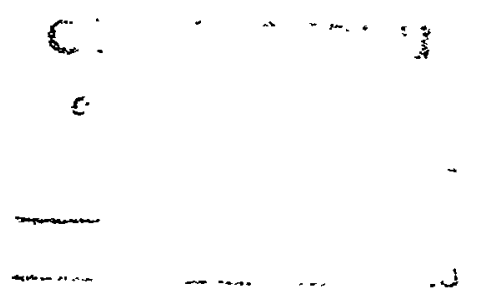




\section{DISCLAIMER}

Portions of this document may be illegible in electronic image products. Images are produced from the best available original document. 


\section{TABLE OF CONTENTS}

$\underline{\text { Section }}$ Page

TABLE OF CONTENTS $\ldots \ldots \ldots \ldots \ldots \ldots \ldots \ldots \ldots \ldots \ldots \ldots \ldots \ldots \ldots \ldots \ldots \ldots \ldots$ iii

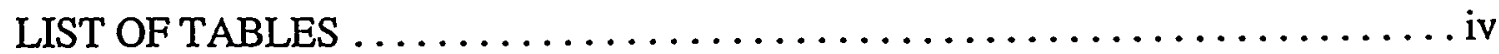

LIST OF FIGURES $\ldots \ldots \ldots \ldots \ldots \ldots \ldots \ldots \ldots \ldots \ldots \ldots \ldots \ldots \ldots \ldots \ldots \ldots \ldots \ldots \ldots$ iv

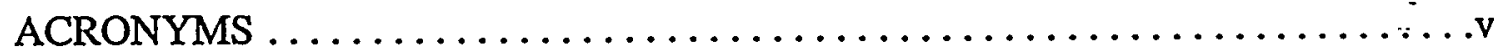

EXECUTIVE SUMMARY $\ldots \ldots \ldots \ldots \ldots \ldots \ldots \ldots \ldots \ldots \ldots \ldots \ldots \ldots \ldots \ldots$ vi

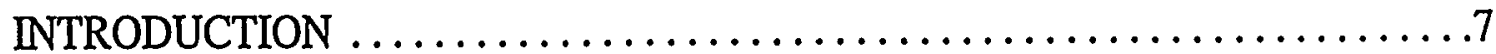

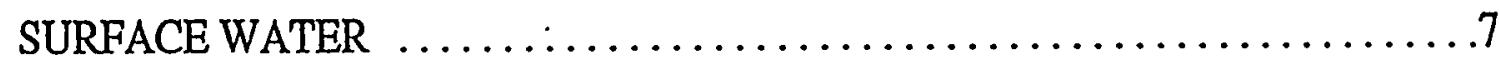

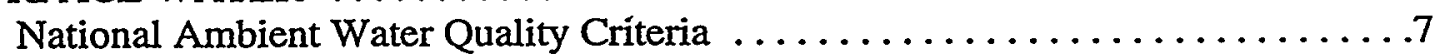

EPA Region IV Screening Values $\ldots \ldots \ldots \ldots \ldots \ldots \ldots \ldots \ldots \ldots \ldots \ldots \ldots$

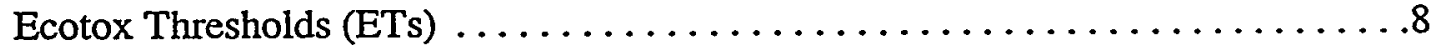

Oak Ridge National Laboratory (ORNL) $\ldots \ldots \ldots \ldots \ldots \ldots \ldots \ldots \ldots . . \ldots$

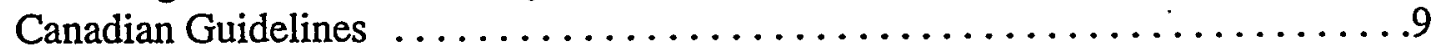

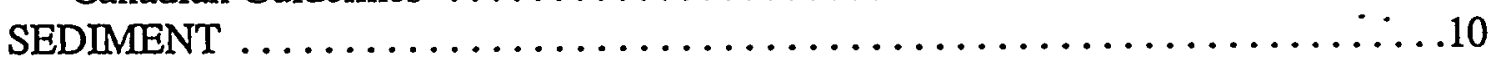

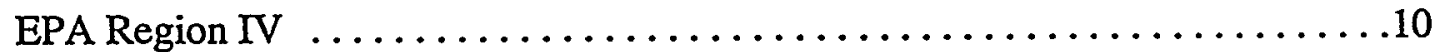

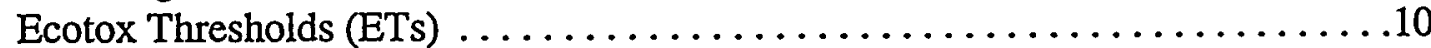

Oak Ridge National Laboratory (ORNL) $\ldots \ldots \ldots \ldots \ldots \ldots \ldots \ldots \ldots \ldots \ldots \ldots \ldots \ldots$

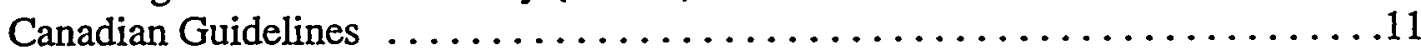

Dutch Sediment Quality Standards $\ldots \ldots \ldots \ldots \ldots \ldots \ldots \ldots \ldots \ldots \ldots \ldots \ldots \ldots \ldots$

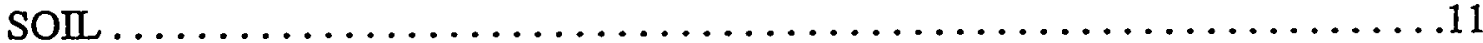

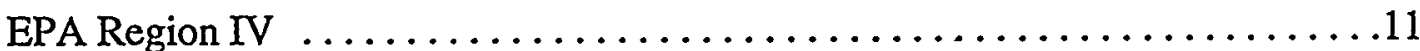

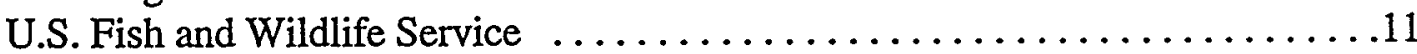

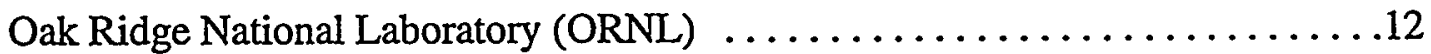

Canadian Council of Ministers of the Environment (CCME) $\ldots \ldots \ldots \ldots \ldots \ldots 12$

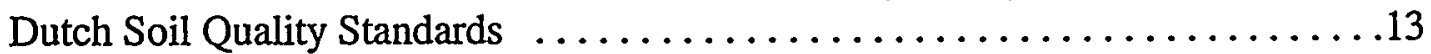

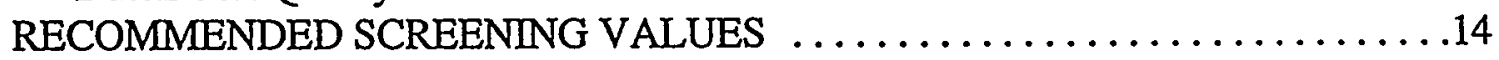

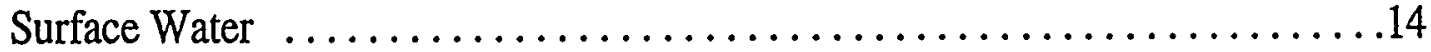

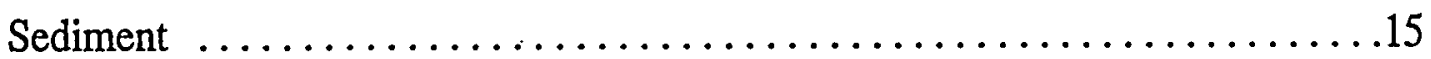

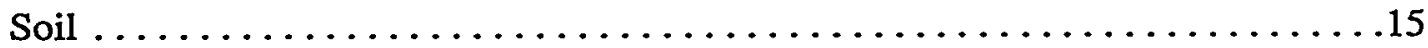

Protocol for Ecological Screening Values . . . . . . . . . . . . . . . . . . 17

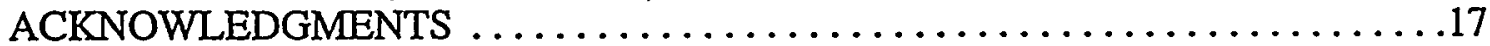

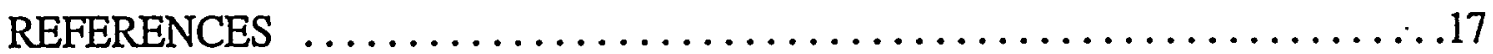

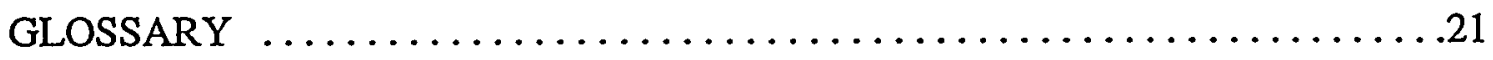

Surface Water, Sediment, and Soil $\quad, \quad$ Page iii 


\section{LIST OF TABLES}

Table

Page

1 Comprehensive Listing of Ecological Screening Values $(\mu \mathrm{g} / \mathrm{L})$

for Surface Water. 23

2 Comprehensive Listing of Ecological Screening Values for Sediment. ..........36

3 Comprehensive Listing of Ecological Screening Values ( $\mathrm{mg} / \mathrm{kg}$ ) for Soil......43

$4 \quad$ Ecological Screening Values $(\mu \mathrm{g} / \mathrm{L})$ for Surface Water...................................53

$5 \quad$ Ecological Screening Values for Sediment......................................................60

$6 \quad$ Ecological Screening Values $(\mathrm{mg} / \mathrm{kg}$ ) for Soil...............................................64

\section{LIST OF FIGURES}

1 Distribution (\%) of ESV's for surface water by source......................................15

$2 \quad$ Distribution (\%) of ESV's for sediment by source. .............................................16

$3 \quad$ Distribution (\%) of ESV's for soil by source. ............................................. 16 


\section{ACRONYMS}

\begin{tabular}{|c|c|c|}
\hline AWQC & \multicolumn{2}{|l|}{ Ambient water quality criteria } \\
\hline ARAR & \multicolumn{2}{|l|}{ Applicable or relevant and appropriate requirements } \\
\hline CCME & \multicolumn{2}{|c|}{ Canadian Council of Ministers of the Environment } \\
\hline CERCLA & \multicolumn{2}{|c|}{ Comprehensive Environmental Response, Compensation, and Liability Act } \\
\hline CLP & Contract laboratory program & $=$ \\
\hline $\mathrm{CV}$ & Chronic value & \\
\hline DOE & U.S. Department of Energy & \\
\hline $\mathrm{EC}_{50}$ & Median effective concentration & \\
\hline EPA & U.S. Environmental Protection Agency & \\
\hline ER-L & Effects range-low & \\
\hline ESV & Ecological screening value & \\
\hline ET & Ecotox threshold & \\
\hline FACR & Final acute-chronic ratio & \\
\hline FAV & Final acute value & \\
\hline $\mathrm{LC}_{50}$ & Median lethal concentration & \\
\hline LOEC & Lowest observed effect concentration & \\
\hline LOAEL & Lowest observed adverse effect level & \\
\hline MACT & Maximum acceptable toxicant concentration & \\
\hline MHSPE & Dutch Ministry of Health, Spatial Planning, and Environment & \\
\hline MPC & Maximum permissible concentration & \\
\hline NAWQC & National ambient.water quality criteria & . \\
\hline NOAA & National Oceanic and Atmospheric Administration & \\
\hline NOEC & No observed effect concentration & \\
\hline NPER & No potential effects range & \\
\hline NSTP & National status and trends program & \\
\hline ORNL & Oak Ridge National Laboratory & \\
\hline OSWER & EPA Office of Solid Waste and Emergency Response & \\
\hline $\mathrm{PCB}$ & Polychlorinated biphenyl & \\
\hline PQL & Practical quantification limit & \\
\hline $\mathrm{RCRA}$ & Resource Conservation and Recovery Act & \\
\hline SQB & Sediment quality benchmark & \\
\hline SQG & Soil quality guideline & \\
\hline TEC & Threshold effects concentration & \\
\hline TEL & Threshold effect level & \\
\hline USFWS & U.S. Fish and Wildlife Service & \\
\hline
\end{tabular}




\section{EXECUTIVE SUMMARY}

The decision making process associated with the environmental remediation program at SRS is often risk-based. This approach, which includes both ecological and human health risk assessment, incorporates screening protocols to identify constituents that pose adverse effects. The use of benchmarks or screening values are essential to this process and in identifying constituents of potential concern. This report presents a comprehensive listing of ecological screening values (ESV's) for surface water, sediment, and soil. The sources of these non-radiological ESV's include the U.S. Environmental Protection Agency (EPA), U.S. Fish and Wildlife Service (USFWS), Environment Canada, Canadian Council of Ministers of the Environment (CCME), Oak Ridge National Laboratory (ORNL), the Ministry of Health, Spatial Planning, and Environment of the Netherlands, and the scientific literature. The basis for how these ESV's are derived is also discussed. The report concludes with a listing of recommended ESV's and describes the rationale used to propose a value from multiple sources. The protocol for applying ESV's in conducting ecological risk assessments is also presented. It should be noted that the ecological screening values presented in this report should be used for screening purposes only and are inappropriate for setting remedial action cleanup levels. 


\section{INTRODUCTION}

One of the principal components of the environmental remediation program at the Savannah River Site (SRS) is the assessment of ecological risk. Required by CERCLA, RCRA, and DOE orders, ecological risk assessment can be used to identify environmental hazards and evaluate remedial action alternatives. An initial task of the ecological risk assessment is to identify constituents that potentially or adversely affect the environment. Typically, this is accomplished by comparing concentrations in surface water, sediment, or soil with regulatory or technically defensible screening values. This process can eliminate many constituents from further consideration in the risk assessment, but it also identifies those that require additional evaluation.

This document provides a comprehensive listing of ecological screening values (ESV's) for surface water, sediment, and soil. Sources of these benchmarks were the U.S. Environmental Protection Agency (EPA), U.S. Fish and Wildlife Service (USFWS), Oak Ridge National Laboratory (ORNL), the Canadian Council of Ministers of the Environment (CCME), the Dutch Ministry of the Environment, and the scientific literature. It should be noted that ecological screening values are continuously revised by the various issuing agencies. The references section of this report provides the citations of each source and, where applicable, the internet address where they can be obtained electronically. Because no radiological screening values have been issued for ecological risk assessment, the values presented here are for nonradiological contaminants. Included is a general description of how the screening values were derived and a listing of recommended ecological screening values that can be used for environmental risk assessment at the SRS and other locations. These values should be used for screening purposes only and do not represent remedial action cleanup levels. Their use at locations other than SRS should take into account environmental variables such as water quality, soil texture, flora and fauna, and other ecological attributes specific to the ecosystem potentially at risk.

\section{SURFACE WATER}

The methods used to derive ecological screening values are generally based on toxicity testing (Suter and Tsao 1996).The simplest screening benchmarks are toxicity test endpoints. Toxicity tests are conventionally categorized as acute - (48-96 hours in duration, use juvenile or adult organisms; endpoints are $\mathrm{LC}_{50}$ or $\mathrm{EC}_{50}$ ) or chronic (include all or most of the lifecycle of the test organisms; endpoint is the chronic value). Test endpoints can be calculated two ways: (1) a level of effect is estimated by fitting a function (e.g., probit or logit) to the concentration-response data to derive a model; then by regression analysis, a concentration can be estimated that causes an effect (e.g., $\mathrm{LC}_{50}$ ) and (2) hypothesis testing can be used to determine if tested concentrations are significantly (i.e., statistically) different from a control. The lowest concentration causing such an effect is the Lowest Observed Effect Concentration (LOEC). The highest concentration for which there were no such effects is called the No Observed Effect Concentration (NOEC). The geometric mean of the LOEC and NOEC is termed the Chronic Value (CV) and was formerly called the Maximum Acceptable Toxicant Concentration (MATC).

\section{National Ambient Water Quality Criteria}

The only values consistently used to screen aqueous contaminants in the United States are the 
U.S. National Ambient Water Quality Criteria for the protection of aquatic life (NAWQC). NAWQC are regulatory values that are intended to protect most aquatic species most of the time with reasonable confidence (Stephan et al. 1985). Suter and Tsao (1996) state that some chronic NAWQC are based on protection of humans or other piscivorous organisms rather than protection of aquatic organisms. NAWQC are available for 113 chemicals (Table 1).

NAWQC are applicable or relevant and appropriate requirements (ARARs). If NAWQC are exceeded during the screening process, the constituent is identified as constituent of potential concern (COPC). NAWQC must be based on results from at least eight acute toxicity tests from eight different families and three chronic tests.

Acute NAWQC values are defined as one-half of the Final Acute Value (FAV). The FAV is the 5 th percentile of the distribution of $48-96 \mathrm{hr} \mathrm{LC}_{50}$ values or equivalent median effective concentration $\left(\mathrm{EC}_{50}\right)$ value for the specific chemical. The acute NAWQC values are intended to correspond to concentrations that would cause less than $50 \%$ mortality in $5 \%$ of exposed populations in a relatively brief exposure. Chronic NAWQC values are calculated by dividing the FAV by the Final Acute-Chronic Ratio (FACR). The FACR is the geometric mean of quotients of at least three $\mathrm{LC}_{50} / \mathrm{CV}$ ratios from tests of different families of aquatic organisms (Stephan et al. 1985).]

\section{EPA Region IV Screening Values}

EPA Region IV surface water screening values were derived by the Region IV Water Management Division (Table 1). These values were obtained from EPA Water Quality Criteria documents and represent the chronic ambient water quality criteria values for the protection of aquatic life. The ambient surface water quality criteria are intended to protect $95 \%$ of the species, $95 \%$ of the time. If there was insufficient information available to derive a criterion, the lowest reported effect level was used with the application of a safety factor of ten to protect for a more sensitive species. A safety factor of ten was also used to derive a chronic value if only acute information was available.

Region IV acute screening values are the same as NAWQC; if no NAWQC value is available, the Region IV screening value is derived by taking the lowest acute $\mathrm{LC}_{50}$ or $\mathrm{EC}_{50}$ and dividing by 10. Similarly, the Region IV chronic screening values are the same as NAWQC; if no NAWQC value is available, the chronic screening value is derived by taking the lowest chronic value and dividing by 10 . If no chronic value exists, the acute value was divided by 10 . Values for metals assume a hardness factor of $50 \mathrm{mg} / \mathrm{L} \mathrm{CaCO}_{3}$. The screening value for $\mathrm{pH}$ ranges between 6.5 and 9.0 (EPA 1995).

\section{Ecotox Thresholds (ETs)}

The EPA Office of Solid Waste and Emergency Response (OSWER) has developed mediaspecific benchmark values for those chemicals commonly found in surface water, sediment and soil samples at Superfund sites (values for soil are still being developed). The values (Table 1), which are referred to as Ecotox Thresholds (ETs), are defined as media-specific contaminant concentrations above which there is sufficient concern regarding adverse ecological effects to warrant further site investigation (EPA 1996). ETs are designed to provide Superfund site managers with a tool to efficiently identify contaminants that may pose a threat to ecological recep- 
tors and focus further site activities on those contaminants and the media in which they are found. ETs are meant to be used for screening purposes only; they are not regulatory criteria, site-specific cleanup standards, or remediation goals. For those chemicals with the potential to bioaccumulate to toxic levels (e.g., methyl mercury, polychlorinated biphenyls (PCBs), DDT, dioxins, and lead) in upper trophic wildlife, these benchmarks may not be low enough at some sites.

The preferred surface water ETs are the chronic NAWQC values. Threshold valuës for metals are expressed as dissolved, rather than total; concentrations. Values for metals assume a water hardness of $100 \mathrm{mg} / \mathrm{L} \mathrm{CaCO}_{3}$. If chronic NAWQC values are unavailable, EPA-derived final chronic values (FCVs) are used. The maximum concentration of each chemical at a site is compared to the medium-specific ET to evaluate whether further risk assessment for the chemical is warranted. Because non-residue based NAWQC have been developed for a limited number of contaminants, ETs are also calculated using the Great Lakes Water Quality Initiative methods ( 40 CFR 122 et al.). These Tier II values were developed.so that aquatic benchmarks could be established with fewer data than are required for the NAWQC. Approximately half of the Ecotox Tier II values were taken from Suter and Mabry (1994). These values have been revised and are discussed in the next section.

The ET software, which is available on the internet, calculates site-specific ETs. by adjusting for $\mathrm{pH}$ and hardness in surface water and total organic carbon in sediment. The software can also compare the site-specific ETs to the concentrations detected at the site.

\section{Oak Ridge National Laboratory (ORNL)}

ORNL (Suter and Tsao 1996, Suter 1996) of ORNL compiled a list of three conventional aquatic benchmarks based on regulatory criteria or standard test endpoints. These conventional benchmarks included the NAWQC described above, Tier II values (secondary acute and secondary chronic values), and lowest chronic values for five categories of organisms (fish, daphnids, non-daphnid invertebrates, aquatic plants, and "all organisms"). They are calculated in accordance with the EPA's Proposed Water Quality Guidance for the Great Lakes System (EPA 1993). The secondary acute and secondary chronic values are equivalent to the final acute value (FAV) and final chronic value (FCV), respectively. These values are based on fewer data than what is required to calculate NAWQC values (i.e., fewer families of test organisms). These values are expected to be higher than NAWQC in no more than $20 \%$ of cases.

The lowest chronic values compiled by Suter and Tsao (1996) are either the lowest values reported in the literature for a given organism, or the estimated lowest chronic value extrapolated from 96-hour $\mathrm{LC}_{50}$ 's. Chronic values are also used to calculate the chronic NAWQC, but the lowest chronic value may be lower than the chronic NAWQC. Additional information on ORNL's screening values is described by Sample et al. (1998).

\section{Canadian Guidelines}

These threshold values take into consideration the protection of aquatic life; the basis for these values is determined by the CCME water quality guidelines task group (Environment Canada 1995a). In 1987, this task group published Canadian Water Quality Guidelines. These guidelines have been distributed by the United Nations Environment Program and the World Health 
Organization and are currently used in 45 countries.

Originally, the guidelines dealt with substances found in freshwater only. Subsequently, the guidelines have expanded to include marine water, sediment and residues in plant and animal tissue. The task group plans to update the entire 800-plus pages of the guidelines and make it available electronically in 1999 .

\section{SEDIMENT}

Sediment is the fine, inundated or semi-saturated soil that exists on the bottom of lakes, rivers, streams, and wetlands. Recently, protecting sediment quality has been viewed as a logical and necessary extension of water quality protection (Adams et al. 1992, cited by Jones et al. 1997). Sediment quality benchmarks (SQBs) have been derived using analytical chemistry, toxicity test results, and field survey data (Jones et al. 1997). Accordingly, it is recommended that multiple benchmarks be used to evaluate sediment quality.

\section{EPA Region IV}

EPA Region IV's sediment screening values (Table 2) were derived from statistical interpretation of effects databases obtained from the literature as reported in publications from the State of Florida (MacDonald 1994), the National Oceanic and Atmospheric Administration (NOAA) (Long and Morgan 1990), and Long et al. (1995). The selected effect level is the lower of the effects range-low (ER-L) (Long et al. 1995) and threshold effect level (TEL) (MacDonald et al. 1996). The ER-L value is the tenth percentile of the distribution of various toxic effects thresholds for various organisms in sediments (Will and Suter 1995). The ER-L for antimony was taken from Long and Morgan (1990). These values are generally based on observations of direct toxicity, and are based predominantly on marine environments. When the Contract Laboratory Program's (CLP) practical quantification limit (PQL) is above the effect level the screening value defaults to the PQL. For those contaminants whose screening values are based on the PQL, data reported below the required quantification limit (e.g., J-flagged data) should be compared to the "effects level" number.

\section{Ecotox Thresholds (ETs)}

Proposed sediment quality criteria (SQC) have been published by the EPA Office of Water for acenaphthene, dieldrin, endrin, fluoranthene, and phenanthrene (Table 2). These values were derived using the equilibrium partitioning method. When SQCs are unavailable, sediment quality benchmarks (SQBs) are used. SQBs are derived in the same manner as the SQCs except that a Tier II secondary chronic value is substituted for the AWQC or FCV in the calculation. Effects Range-Low (ER-L) values (Long et al. 1995) are used when a SQC or SQB is unavailable. OSWER notes that there is relatively low correlation between the incidence of effects and the ER-L's for mercury, nickel, total PCBs, and DDT (Long et al. 1995) and that the ET's for these four chemicals should be used cautiously.

\section{Oak Ridge National Laboratory (ORNL)}

Jones et al. (1997a) of ORNL compiled ecological screening values for sediment in a 1997 revision of earlier works. These included benchmarks developed for NOAA and the Florida De- 
partment of Environmental Protection for inorganic and organic chemicals. Also included were screening values for non-ionic organic chemicals which were derived by equilibrium partitioning. Other screening values contained in the ORNL document (Jones et al. 1997) were taken from the Ontario Ministry of the Environment, EPA Region IV, and Ecotox Threshold Values. With the exception of lowest chronic values for fish, daphnids, and non-daphnid invertebrates, the ORNL screening values (Jones et al. 1997) are either identical to those presented in this report or they were derived from less recent reports. Thus, the ORNL screening values for sediment are not included herein. The ORNL report does, however, include useful information on analytical chemistry approaches for deriving benchmarks.

\section{Canadian Guidelines}

Sediment quality guidelines (Environment Canada 1995) were developed following the methods that are described in a formal protocol (CCME 1995). The guideline derivation methods rely on the spiked-sediment toxicity test approach and the National Status and Trends Program (NSTP) approach (Long and Morgan 1990; Long 1992; Long and MacDonald 1992; Long et al. 1995; MacDonald 1994), with modifications. Information is also required to assess the relative importance of sediment characteristics (e.g., total organic carbon, grain size, acid volatiles sulfides) in modifying the bioavailability of chemicals, as well as the predictability of these relationships under field situations. In addition, the potential for adverse effects on higher trophic levels resulting from the bioaccumulation of persistent toxic substances is addressed through the use of additional methods (e.g., involving the evaluation of bioaccumulation factors and tissue residue guidelines for the protection of wildlife consumers of aquatic life).

\section{Dutch Sediment Quality Standards}

The Dutch Ministry standards (MHSPE 1994) for sediment (Table 2) are the same as those for soil (Table 3). Because the chemistry and structure of sediment and soil can differ, sediment benchmarks based on the Ministry should be used with caution. The derivation of the soil (i.e., sediment) quality standards is discussed in the ensuing section.

\section{SOIL}

\section{EPA Region IV}

Terrestrial assessments are one of the least developed aspects of ecological risk assessment. Screening values for soils have not been issued by EPA. Site-specific soil screening values may be submitted based on information concerning potential effects for contaminants whose mode of toxicity is through direct exposure (e.g., soil invertebrates such as earthworms). For those contaminants which biomagnify, screening values may be back-calculated from acceptable tissue levels in prey items through two trophic transfers from the abiotic medium. Screening values should be based on contaminant levels associated with ecological effects, instead of area or regional background levels.

\section{U.S. Fish and Wildlife Service}

One of the earliest compilations of soil screening values was presented by Beyer (1990) of the USFWS. He listed over 200 contaminants from Japan, Netherlands, Canada, United States, and 
the former Soviet Union. Screening levels from the Netherlands, which are sanctioned by EPA Region IV, were taken from the interim Dutch Soil Cleanup Act (Richardson 1987) values issued in the 1980s. Three categories were identified by the Dutch: (1) category A refers to background concentrations in soil or detection limits, (2) category B refers to moderate soil contamination that requires additional study, and (3) category $C$ refers to threshold values that require immediate cleanup. USFWS screening values are presented in Table 3.

\section{Oak Ridge National Laboratory (ORNL)}

ORNL identified soil screening values specific to DOE sites for soil invertebrates and microbial processes (Efroymson et al. 1997a), and terrestrial plants (Efroymson et al. 1997b). The soil benchmarks for invertebrates (Table 3) were derived using NOAA's effects range-low (Long and Morgan 1990) approach supported by information from field and laboratory studies, bibliographic data bases, and the published literature. Assumptions, uncertainties, and how benchmarks were calculated are detailed in Efoymson et al. (1997a). LOEC's were rank ordered and a value was selected that most closely approximated the 10th percentile of the distribution. If less than ten values were available, the lowest NOEC was used. If ten or more values were available, the 10th percentile was used. Interpolation and the authors expert judgement were used to derive some benchmarks (Efoymson et al. 1997 a,b). Because both natural soils and nutrient/mineral solutions have been used in toxicity testing, Efoymson et al. (1997b) presents screening benchmarks for terrestrial plants for both soil and soil solution. Values for plant benchmarks were derived in the same way that was used for invertebrates and microbial processes (Efoymson et al. 1997b).

\section{Canadian Council of Ministers of the Environment (CCME)}

The Canadian protocol for deriving environmental soil quality guidelines (SQGs) takes into consideration levels of ecological protection, endpoints, availability of soil toxicity data, receptor arrays, and exposure pathways for four types of land use (CCME 1996). In 1997, the CCME issued soil quality guidelines for 20 constituents (CCME 1997). The guidelines (Table 3) were derived specifically for the protection of ecological receptors in the environment or for the protection of human health associated with agricultural, residential/parkland, commercial, and industrial land use types (CCME 1997). The land use most closely associated with ecological resources was agricultural. Although the primary activity for this land use type is growing crops or livestock, it also includes agricultural lands which provide habitat for resident and transitory wildlife as well as native flora (CCME 1997).

The 1997 soil quality guidelines were issued on a constituent-by-constituent basis after a comprehensive review of the physical/chemical characteristics, background levels in Canadian soils, toxicity and environmental fate, and behavior of each constituent were derived using toxicological data to determine the threshold level for key receptors. The derivation process for SQG's considers adverse effects from direct soil contact and from the ingestion of soil and food. Four approaches were used to evaluate contact with soil: (1) weight of evidence, (2) LOEC method, (3) median effects method, and (4) comparison with nutrient and energy cycling.

The weight-of-evidence method, which is a modification of Long and Morgan (1990), estimates no adverse effects. For agricultural land use, the 25 th percentile of the effects and no ef- 
fects data distribution was chosen as the "no potential effects range" (NPER). An uncertainty factor was then applied to the NPER to give the "threshold effects concentration" (TEC). When the data were inadequate to perform a weight-of-evidence method, the TEC was derived by extrapolating from the lowest available LOEC divided by an uncertainty factor. Thus, the TEC will lie somewhere below the lowest reported effect concentration. When LOEC values are unavailable, the TEC is derived using the median effects method. Here, the TEC is obtained by extrapolating from the lowest available $\mathrm{EC}_{50}$ or $\mathrm{LC}_{50}$ datum using an uncertainty-factor ranging from five to ten. Thus, the TEC is estimated in the region of predominantly no effects in the data distribution.

Once the TEC is calculated, it is compared to nutrient and energy cycling data for selected microbial processes. If the microbial value is less than the TEC, microbial nutrient and energy cycling processes may experience adverse effects at the TEC level. In this case, the geometric mean of the microbial and TEC values is selected as the SQG for soil contact. If the TEC is less than the microbial value, the TEC becomes the SQG.

The procedure for deriving SQG's for ingestion of soil and food by grazing livestock and wildlife is only used for agricultural land use (CCME 1997). This process is restricted to a herbivorous food chain, and considers the bioaccumulation of chemicals in plant tissue. Several steps are required for the derivation of a SQG. First, species considered to be most at risk from ingesting soil and food are identified and a daily threshold effects dose is identified based on a minimum of three studies (e.g., two mammal, one avian). Second, the daily threshold effects dose is calculated by dividing the lowest LOAEL by an uncertainty factor. Next, information is gathered including body weight, rate of soil ingestion, and rate of food ingestion for the most sensitive species as well as information on bioavialability and bioconcentration factor specific to the contaminant. This information is used to calculate the SQG in accordance with CCME (1996). Finally, the lower of the two values (soil contact versus ingestion) is used as the final SQG for agricultural (e.g. ecological) use.

\section{Dutch Soil Quality Standards}

During the 1980 s, the Dutch government issued three categories of soil quality values (i.e., A, $\mathrm{B}$, and C). In 1994, the ABC benchmarks were replaced: (1) "A" values became "target values," (2) " $\mathrm{B}$ " values were replaced by the sum of the target value and intervention value divided by two, and (3) "C" values became "intervention values" (MHSPE 1994). The target values indicate the soil quality required for sustainability or, expressed in terms of remedial policy, the soil quality required for the full restoration of the soil's functionality for human, animal, and plant life. Target values were based on standards for drinking water and surface waters. Values for heavy metals, arsenic and fluoride were derived from the analysis of field data from relatively pollution-free rural areas and aquatic sediments regarded as uncontaminated. The target values for soil were based on the target values for surface waters when scientificaily possible.

Intervention values, which apply to both terrestrial soil and to soil from the beds of rivers, lakes, etc. (i.e., sediments), indicate that the concentration levels of the contaminants in the soil above which the functionality of the soil for human, plant, and animal life is seriously impaired or threatened. Concentrations in excess of the intervention values correspond to-serious contamination. These values are based on ecotoxicological effects that are quantified in terms of 
the concentrations in the soil at which $50 \%$ of the species actually (or potentially) occurring may undergo adverse effects.

In 1997, the Dutch Ministry issued maximum permissible concentrations (MPC's) for 18 metals (Crommentuijn et al. 1997) using three methods. When NOEC's were available for at least four taxons, statistical extrapolation was used. When only $L_{50}$ or a few NOEC's were available, a modification of the EPA method was used. When no laboratory data were available, equilibrium partitioning was used to derive a benchmark value. The Dutch values are based on ecotoxicological effects that are quantified in terms of the concentrations at which $50 \%$ of the species and $50 \%$ of the microbial processes in the ecosystem are threatened or adversely affected.

\section{RECOMMENDED SCREENING VALUES}

A listing of the recommended ecological screening values for the SRS remediation program are presented in Tables 4-6. These values are presented chronologically for surface water, sediment, and soil. Sources for each screening value are identified to the right of the constituent of potential concern. The rationale used to select a screening value was based on a several factors. Regulatory benchmarks that were applicable or relevant and appropriate requirements (ARAR's) were ranked first in importance. ARAR's, which are requirements issued under federal or state law, are enforceable and have been used consistently in SRS risk assessments commensurate with EPA Region IV guidance. In the absence of regulatory benchmarks, the lowest or most conservative screening values were selected using the most recently published information. At first glance some of the recommended screening values may appear contradictory. For example, the recommended sediment ESV for 1,2,4-trichlorobenzene is $9,200 \mu \mathrm{g} / \mathrm{kg}$ whereas it is $10 \mu \mathrm{g} / \mathrm{kg}$ for total trichlorobenzene. This is because the former value was published by EPA (1996) and the latter by MHSPE (1994). In these situations, the investigator must take into consideration what chemical constituent (e.g., specific compound vs. category of compound) is of interest, what receptor species have been identified, and the objective of the study. It should be noted that the goal of this report is to provide investigators with a comprehensive listing of ecological screening values. No attempt is made to endorse a source or to evaluate the derivation process. Ultimately, the investigator must determine which values are most appropriate for their objectives and study.

\section{Surface Water}

The chronic NAWQC values (EPA 1995) were ranked first in importance as ecological screening values for surface water. These are applicable or relevant and appropriate requirements, they are consistently used in the risk assessment process, and have regulatory precedent. Of the 201 constituents listed in Table 4, 56 percent were based on NAWQC. If NAWQC values were not available, EPA Ecotox Threshold (EPA 1996) values (i.e., final chronic values) were used. It should be noted that many Tier II values from Ecotox Thresholds (EPA 1996) were based on calculations by Suter and Mabry (1994) of ORNL. For these values, the secondary chronic Tier II value (Suter and Tsao 1996) was used because it was more conservative and based on more recent data. This application resulted in a markedly larger number of ORNL values compared to Ecotox values. If a screening value was not available from any of the three sourcesidentified previously, the lowest chronic value or Canadian (Environment Canada 1998) benchmark was 
used. For some constituents, only a single source was available. The number of recommended screening values by source was as follows: (1) NAWQC/EPA Region IV- 112, (2) Ecotox Thresholds - 2, (3) ORNL values - 46, and (5) Canadian water guidelines - 41. The NAWQC and secondary chronic values represented 56 and 24 per cent, respectively, of the recommended screening benchmarks for surface water (Figure 1). The Canadian values comprised 20 per cent of the benchmarks.

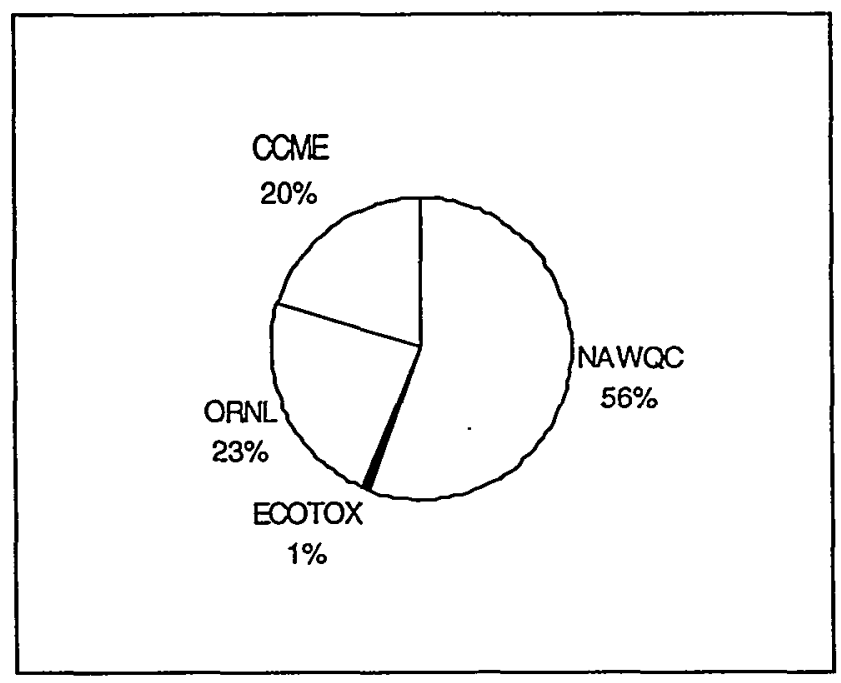

Figure 1. Distribution (\%) of ESV's for surface water by source.

\section{Sediment}

The recommended ecological screening values for sediment are presented in Table 5. As was the case with surface water, sediment screening values that were applicable or relevant and appropriate requirements from EPA Region IV (EPA 1995) ranked first in importance. The ARAR's comprised 35\% of the 115 constituents (Figure 2). For the remaining non-ARAR constituents, the lowest or most conservative value was used (Table 2). When the Dutch Ministry intervention value was the only available screening value, this number was divided by 10 to obtain the final recommended value. Listed in order of decreasing frequency, sources of soil screening values were as follows: (1) Dutch Ministry (MHSPE 1994) - 42\%, (2) EPA Region IV (EPA 1995) - 35\%, (3) Ecotox Thresholds (EPA 1996) - 21\%, and (4) Environment Canada (1995) - 2\%.

\section{Soil}

The EPA has not issued ecological screening values for soil. However, work has been initiated by an EPA task group and it is anticipated that screening values will be issued sometime in 1999. Existing ecological soil screening values are limited to those benchmarks issued by the USFWS (Beyer 1990), ORNL (Efroymson et al. 1997a,b), the Dutch (MHSPE 1994, Crommentuijn et al. 1997), and Canada (CCME 1997). The U.S. Fish and Wildlife Service (Beyer 1990) numbers are taken from the Dutch Ministry numbers issued in the 1980's (MHSPE 1994). The 132 recommended soil screening values (Table 6) represent the lowest or most conservative value with three exceptions: (1) when a screening value was available from both the USFWS (Beyer 1990) and Crommentuijn et al. (1997), the latter was used, (2) when target val- 
ues (MHSPE 1994) and MPC's were available, the latter was used, and (3) if only an intervention value was available, it was divided by a factor of 10 to derive the recommended ESV. The use of maximum permissible concentrations was restricted to metals, and are recommended because they are based on more recent data. Including the USFWS, Dutch values constituted $60 \%$ of the recommended values. ORNL benchmarks comprised $38 \%$ whereas the Canadian values comprised $2 \%$ (Figure 3).

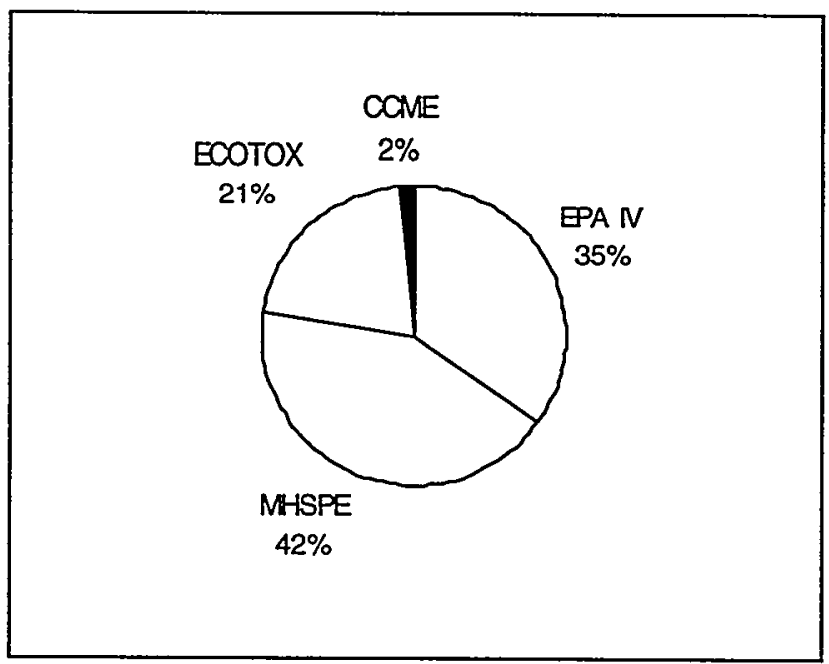

Figure 2. Distribution (\%) of ESV's for sediment by source.

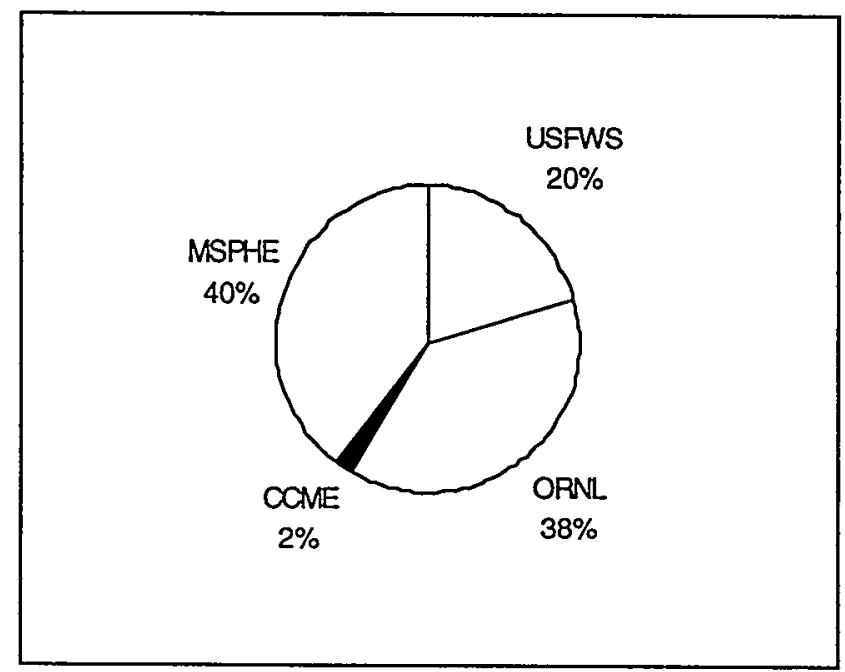

Figure 3. Distribution (\%) of ESV's for soil by source. 


\section{Protocol for Using Ecological Screening Values}

Ecological screening values can be used to identify constituents of potential concern. ESV's do not represent remediation goals or cleanup levels, but should be used as part of the ecological risk assessment initial screening process. Prior to the application of ecological screening values to environmental data, data quality objectives should be established and defined. Verification and validation of data should also be performed when practicable as well as developing a preliminary conceptual model.The protocol for using ecological screening values to identify constituents of potential concern consists of four steps.

Step 1 - Partition the data into the appropriate medium (e.g., surface water, sediment, soil). Units of measurement should be included.

Step 2 - Determine the maximum concentration of each constituent.

Step 3 - Compare the maximum concentration of the constituent with the ecological screening values presented in Table 4 (surface water), Table 5 (sediment), or Table 6 (soil).

Step 4 - If the maximum value does not equal or exceed the ecological screening value, the constituent is eliminated from further consideration. If the concentration of the constituent exceeds the ecological screening value, the constituent is retained for further examination. If there is no screening value available for a constituent, it is also retained for further study and should be addressed in the uncertainty section of the ecological risk assessment.

\section{ACKNOWLEDGMENTS}

The author gratefully acknowledges the technical comments and suggestions that were received. Listed alphabetically, special thanks are extended to Jim Bowers, John Gladden, Linda George, Blake Hart, Laura Haselow, Doug Martinson, Charles Murphy, Winona Specht, and Lynn Wellman.

\section{REFERENCES}

40 CFR 9, 122, 123, 131, and 132. Tuesday, 23 March 1995. Final Water Quality Guidance for the Great Lakes System; Final Rule.

Adams, W.J., R.A. Kimerle, and J.W. Barnett. 1992. Sediment Quality and Aquatic Life Assessments. Environ. Sci. Technol. 26(10):1865-1875.

Beyer, W.N. 1990. Evaluating Soil Contamination. United States Fish and Wildlife Service, Biological Report 90(2).

Canadian Council of Ministers of the Environment (CCME). March 1997. Recommended Canadian Soil Quality Guidelines. Canadian Council of Ministers of the Environment (CCME), Winnipeg, Manitoba.

Canadian Council of Ministers of the Environment (CCME). March 1996. A Protocol for the Derivation of Environmental and Human Health Soil Quality Guidelines. CCME-EPC-101E, Winnipeg, Manitoba. 
Canadian Council of Ministers of the Environment (CCME). 1995. Protocol for the Derivation of Canadian Sediment Quality Guidelines for the Protection of Aquatic Life. Report CCME EPC-98E. Prepared by the Task Group on Water Quality Guidelines, Winnipeg, Manitoba. 38 pp.

Crommentuijn, T., D.F. Kalf, M.D. Polder, R. Posthumus, and E.J. van de Plassche. 1997. Maximum Permissible Concentrations and Negligible Concentrations for Pesticides. RIVM Report No. 601501002.

Efroymson, R.A., M.E. Will, and G.W. Suter. 1997a. Toxicological Benchmarks for Screening Contaminants of Potential Concern for Effects on Soil and Litter Invertebrates and Heterotrophic Process: 1997 Revision. Oak Ridge National Laboratory, Oak Ridge, TN. ES/ER/ TM-126/R2 (http://www.hsrd.ornl.gov/ecorisk/reports.html).

Efroymson, R.A., M.E. Will, G.W. Suter, and A.C. Wooten. 1997b. Toxicological Benchmarks for Contaminants of Potential Concern for Effects on Terrestrial Plants: 1997 Revision. Oak Ridge National Laboratory, Oak Ridge, TN, ES/ER/TM-85/R3 (http://www.hsrd.ornl.gov/ ecorisk/reports.html).

Environment Canada. 1998. "Summary of Canadian Water Quality Guidelines for the Protection of Aquatic Life". Interim draft guidelines transmitted on 20 April 1998 to G.P. Friday from Robert Kent, Head, Water Quality Guidelines and Assessments Section, Guidelines and Standards Division, Environment Canada.

Environment Canada. 1995a. CCME Canadian Water Guidelines-December 1995, Environment Canada, Ottawa, Ontario

Environment Canada. September 1995b. Interim Sediment Quality Guidelines, Soil and Sediment Quality Section Guidelines Division, Ecosystem Conservation Directorate, Evaluation and Interpretation Branch, Ottawa, Ontario

Environmental Protection Agency. January 1996. Ecotox Thresholds, ECO Update, Office of Solid Waste and Emergency Response, Intermittent Bulletin Vol. 3, No. 2, Publication 9345.012FSI, EPA 540/F-95-038 PB95-963324 (http://www.epa.gov/superfund/oerr/r19/ecotox)

Environmental Protection Agency. November 1995. Ecological Screening Values. In: Supplemental Guidance to RAGS: Region 4 Bulletins-Ecological Risk Assessment, Bull. No.2, Atlanta, Georgia. (http://www.epa.gov/region4/wastepgs/oftecser/otsguid.htm)

Environmental Protection Agency. 1993. Water Quality Guidance for the Great Lakes System and Correction; Proposed rules Federal Register 58 (72): 20802-21047.

Environmental Protection Agency. 1985. Ambient Water Quality Criteria for Ammonia. Criteria and Standards Division, Office of Water Regulations and Standards, EPA 440/5-85-001, Washington, D.C. 
Environmental Protection Agency. 1980. Water quality criteria documents; availability. Federal Register 45:79318-79379.

Jones, D.S., G.W. Suter, and R.N. Hull. 1997. Toxicological Benchmarks for Screening Potential Contaminants of Concern for Effects on Sediment-Associated Biota: 1997 Revision, ES/ ER/TM-95/R4, Oak Ridge, TN.

Long, E.R. 1992. Ranges in Chemical Concentrations in Sediments Associated with Adverse Biological Effects. Mar. Pollut. Bull. 24(1):38-45.

Long, E.R. and D.D. MacDonald. 1992. National Status and Trends Program Approach. In: Sediment Classification Methods Compendium. Environmental Protection Agency EPA 823R-92-006.

Long,,E.R. and L.G. Morgan. 1990. The Potential for Biological Effects of Sediment-Sorbed Contaminants Tested in the National Status and Trends Program. NOAA Technical Memorandum NOS OMA 52.

Long, E.R., D.D. MacDonald, S.L. Smith, and F.D. Calder. 1995. Incidence of Adverse Biological Effects within Ranges of Chemical Concentrations in Marine and Estuarine Sediments. Environmental Management 19(1):81-97.

MacDonald, D.D. 1994. Approach to the Assessment of Sediment Quality in Florida Coastal Waters. Prepared for the Florida Department of Environmental Protection. MacDonald Environmental Sciences, Ltd., Ladysmith, British Columbia. Vol. 1, 123 pp.

MacDonald, D.D., R. S. Carr, F.D. Calder, E.R. Long, and C.G. Ingersoll. 1996. Development and Evaluation of Sediment Quality Guidelines for Florida Coastal Waters. Ecotoxicology 5, 253-278.

MHSPE (Ministry of Housing, Spatial Planning, and Environment). 9 May 1994. Intervention Values and Target Values - Soil Quality Standards. Directorate-General for Environmental Protection, Department of Soil Protection, The Hague, The Netherlands.

Richardson, G.M. 1987. Inventory of cleanup criteria and methods to select criteria. Unpublished report, Committee on Industrial site Decommissioning, Industrial Programs Branch, Environment Canada, Ottawa, Ontario.

Sample, B.E., G.W. Suter, R.A. Efroymson, and D.S. Jones. 1998. A Guide to the ORNL Ecotoxicological Screening Benchmarks: Background, Development, and Application. ORNL ES/ER/TM-13615.Oak Ridge, TN. (http://www.hsrd.ornl.gov/ecorisk/reports/html)

Sample, B.E., D.M. Opresko, and G.W. Suter. June 1996. Toxicological Benchmarks for Wildlife: 1996 Revision, ORNL ES/ER/TM-86/R3.Oak Ridge, TN. (http://www.hsrd.ornl.gov/ ecorisk/reports/html)

Stephan, C.E., D.I. Mount, D.J. Hanson, J.H. Gentile, G.A. Chapman, and W.A. Brungs. 1985. 
Guidelines for Deriving Numeric National Water Quality Criteria for the Protection of Aquatic Organisms and Their Uses. U.S. Environmental Protection Agency, PB85-227049, Duluth, Minnesota.

Suter, G.W. 1996. Toxicological Benchmarks for Screening Contaminants of Potential Concern for Effects on Freshwater Biota. Environmental Toxicology and Chemistry Vol. 15 (7): 1232-1241.

Suter, G.W. and C.L. Tsao. June 1996. Toxicological Benchmarks for Screening Potential Contaminants of Concern for Effects on Aquatic Biota: 1994 Revision, ORNL Environmental Sciences Division, Oak Ridge, TN. ES/ER/TM-96/R2. (http://www.hsrd.ornl.gov/ecorisk/reports/html)

Suter, G.W. and J.B. Mabrey. 1994. Toxicological Benchmarks for Screening Potential Contaminants of Concern for Effects on Aquatic Biota: 1994 Revision. Oak Ridge National Laboratory, Oak Ridge, TN. ES/ER/TM-96/R1.

Will, M.E. and G.W. Suter. 1995. Toxicological Benchmarks for Screening Potential Contaminants of Concern for Effects on Soil and Litter Invertebrates and Heterotrophic Process, Oak Ridge National Laboratory, Oak Ridge, TN. 155pp, ES/ER/TM-126/R1 


\section{GLOSSARY}

acute toxicity-causes death or extreme physiological disorders to organisms immediately or shortly following exposure to the contaminant

ARARs (Applicable or relevant and appropriate requirements) - Federal and State standards, requirements, criteria, or limitations that affect RCRA/CERCLA remedial actions

assessment endpoint - an explicit expression of the environmental value that is to be protected. An example of an assessment endpoint would be "the protection of piscivorous birds." The measurement endpoint could be eggshell thinning (DDT).

bioaccumulation - refers to the uptake of a chemical by an organism through all routes of exposure, including ingestion, inhalation, and cutaneous absorption. Bioaccumulation is a general term that encompasses two additional concepts, bioconcentration and biomagnification.

bioaccumulation factor (BAF) - the bioaccumulation factor is similar to the BCF but it includes external and internal (i.e., ingestion) exposure. It is calculated by "adjusting" the BCF using a food chain multiplier for the organism of concern. Bioaccumulation values obtained from the literature can be used to estimate contaminant accumulation and food-chain transfer.

bioconcentration - the process by which a compound is absorbed from water through gills or epithelia tissues and is concentrated in the body; refers to the uptake of a chemical by an aquatic organism from water alone.

bioconcentration factor (BCF) - is the ratio of the concentration of a contaminant in the organisms to the concentration in the immediate environment (soil, water, sediment); the measure of a chemical's tendency to bioconcentrate. The BCF is calculated by dividing the concentration of the chemical in the exposed organism's tissues by the concentration of the chemical in the exposure medium.

biomagnification - the increase in chemical concentration in organism tissues through successively higher trophic levels resulting from chemical transfer in food; higher concentration in the consumer than in the contaminated source

chronic toxicity-involves long-term effects of small doses of a contaminant and their cumulative effects over time. These effects may lead to death of the organism or disruption of such vital functions as reproduction

chronic value - the geometric mean of the LOEC and NOEC (formerly termed the maximum acceptable toxicant concentration (MATC))

$\mathrm{EC}_{50}$-median effective concentration; the concentration at which $50 \%$ of the organisms exhibit a certain physiological or behavioral response (e.g., non-lethal) in a specified period of time (usually 96 hours); is an analog of the $\mathrm{LC}_{50}$ where the endpoint is other than mortality; note: $\mathrm{EC}_{50}$ is time dependent. 
$\mathrm{ED}_{50}$-median effective dose; the dose at which $50 \%$ of the organisms exhibit a certain physiological or behavioral response (e.g., non-lethal) in a specified period of time (usually 96 hours); based on the analysis of nominal (i.e., dead or alive) data. $\mathrm{ED}_{50}$ is time dependent.

endpoint-a characteristic of an ecological component that may be affected by exposure to a stressor

$\mathrm{LC}_{50}$-median lethal concentration; is calculated from population percentage mortalities produced by different concentrations after specified time periods; the environmental concentration at which 50\% of the organisms die in a specified period of exposure time (usually 96 hours); $\mathrm{LC}_{50}$ is time dependent.

$\mathrm{LD}_{50}$-median lethal dose; the administered dose at which $50 \%$ of the experimental organisms die in a specified period of exposure time (usually 96 hours); based on the analysis of nominal (i.e., dead or alive) data; note: $L D_{50}$ is time dependent.

lethal toxicity-causes death directly through disruption of key physiological function; can be caused by acute or chronic toxicity

measurement endpoint - a measurable ecological characteristic that is related to the valued characteristic chosen as the assessment endpoint. Measurement endpoints are often expressed as the statistical or arithmetic summaries of the observations that make up the measurement.

LOEC - lowest observed effect concentration; the lowest concentration that is statistically different from the control and that causes an effect

NOEC - no observed effect concentration; the highest concentration for which there are no such effects

NOEL (no observed effects level) or NOAEL (no observed adverse effects level) - these measures, which are not time-dependent, describe the threshold below which predefined effects are not observed. When this threshold has not been determined, the lowest observed effects level (LOEL) or lowest observed adverse effects level (LOAEL) describe the lowest recorded dosage at which effects were observed. A NOAEL is preferred to a LOAEL, which is preferred to an $\mathrm{LD}_{50}$ or an EC50. Both the NOAEL and LOAEL are estimated by hypothesis testing.

CLP PQL -Contract Laboratory Program Practical Quantitation Limit (PQL). The PQL is analogous to the limit of quantitation (LOQ). It is an interlaboratory concept and is numerically estimated at 5 to 10 times the method detection limit (MDL).

risk-the chance that a hazard or threat will occur: risk $=$ exposure $\mathrm{X}$ potency

stressor-any physical, chemical, or biological entity that can induce an adverse effect

sublethal toxicity-entails symptoms other than death or severe disorder, but may have longterm effects on a population; can be caused by acute or chronic toxicity 


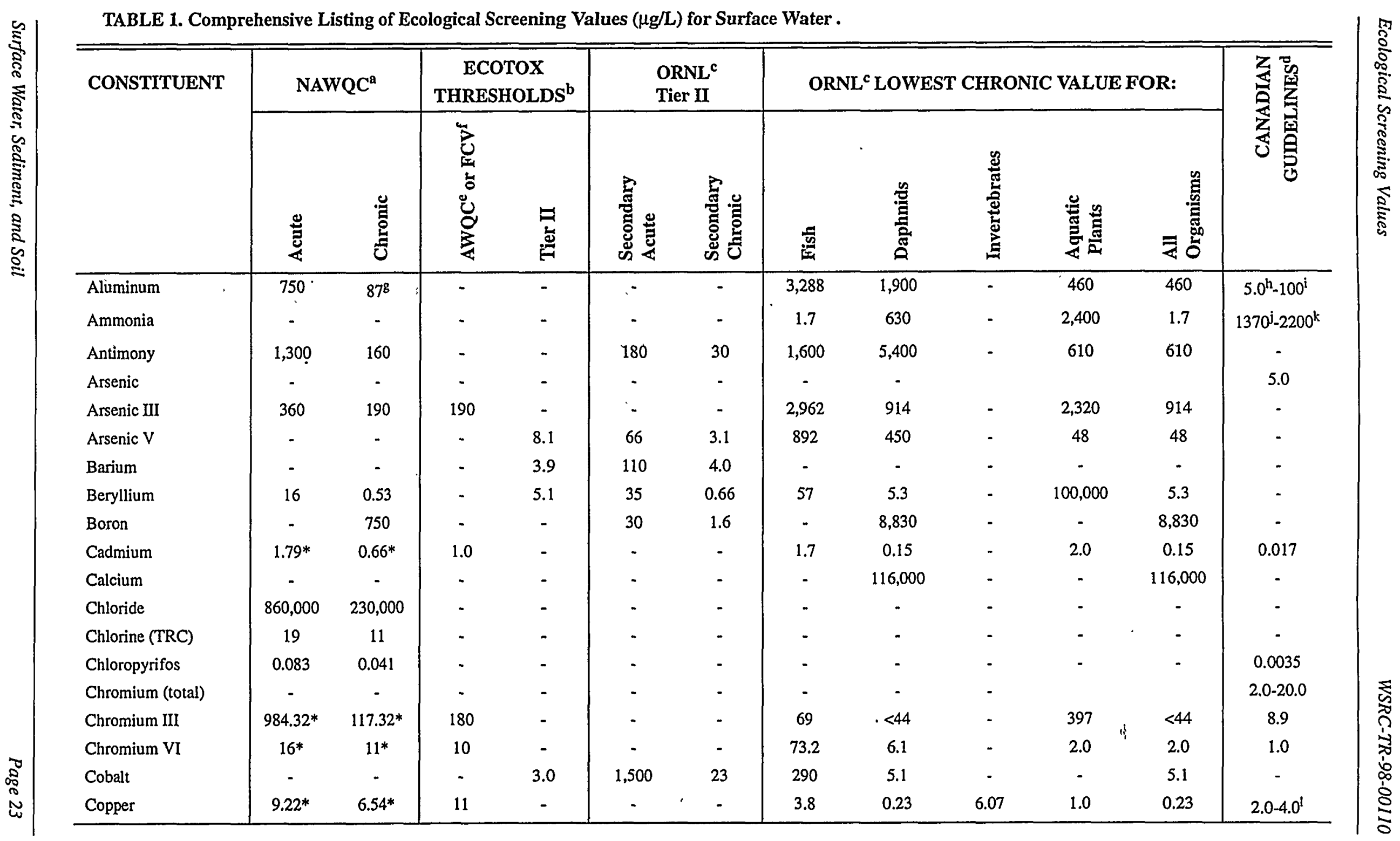




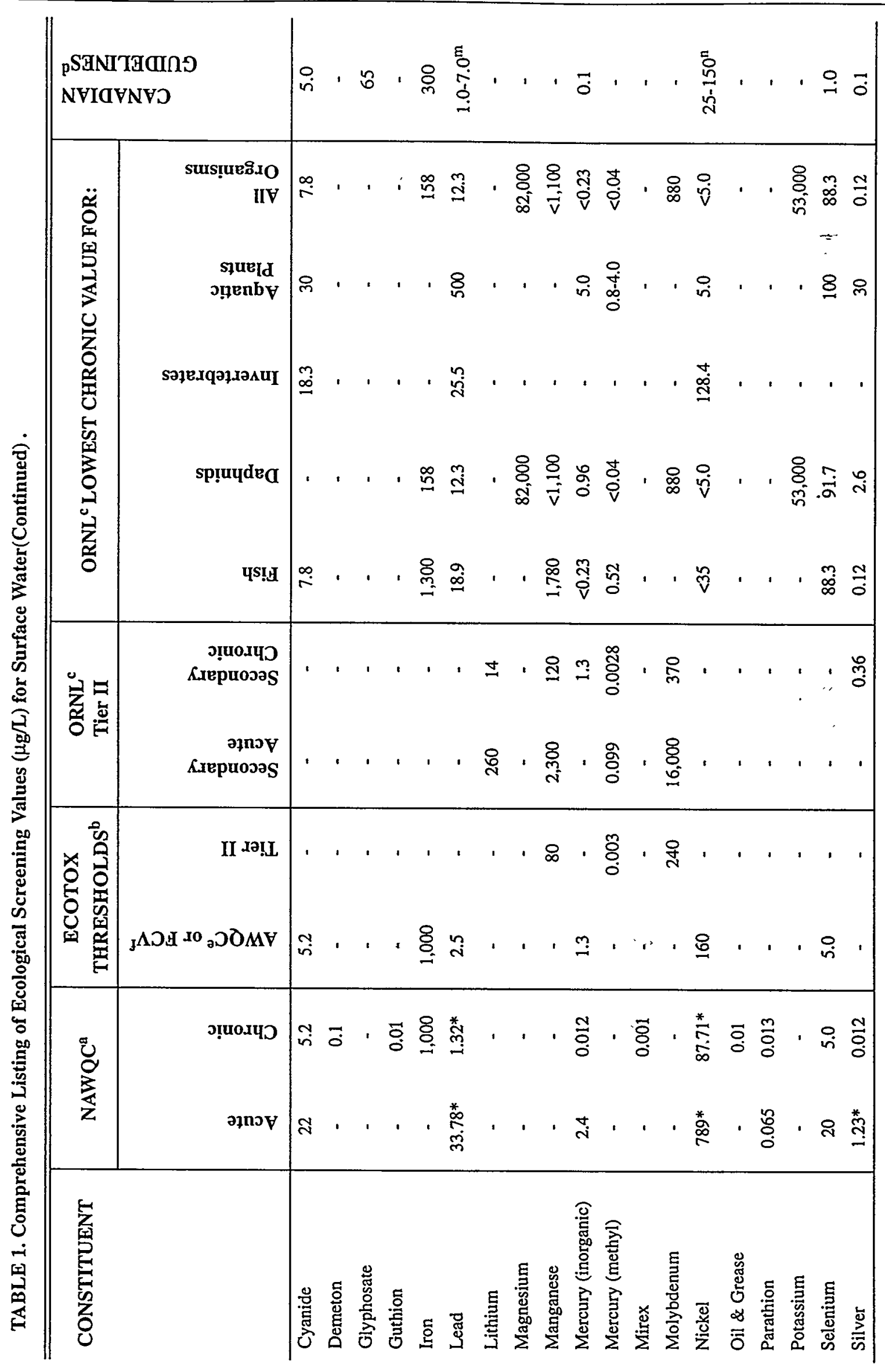




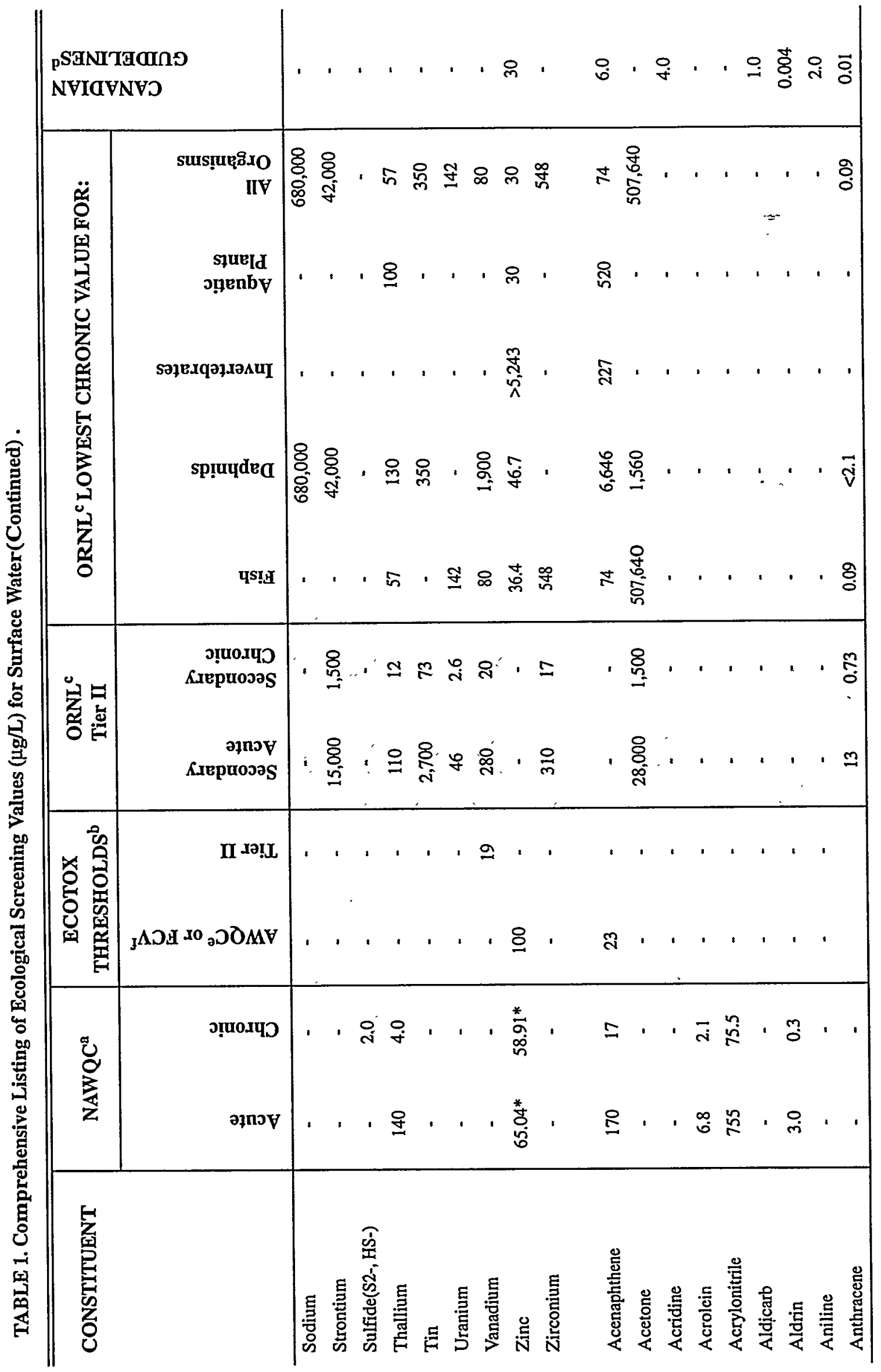




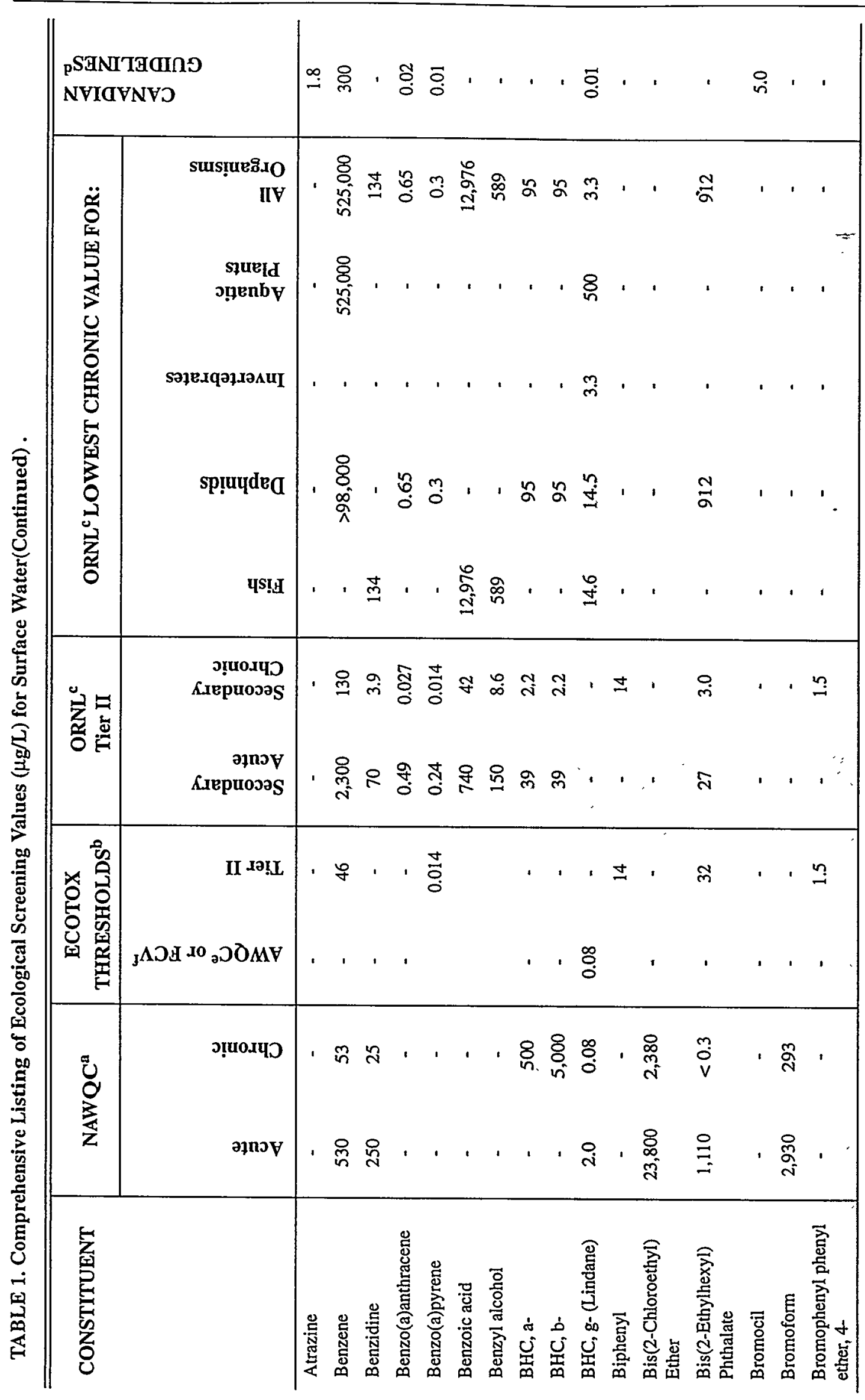




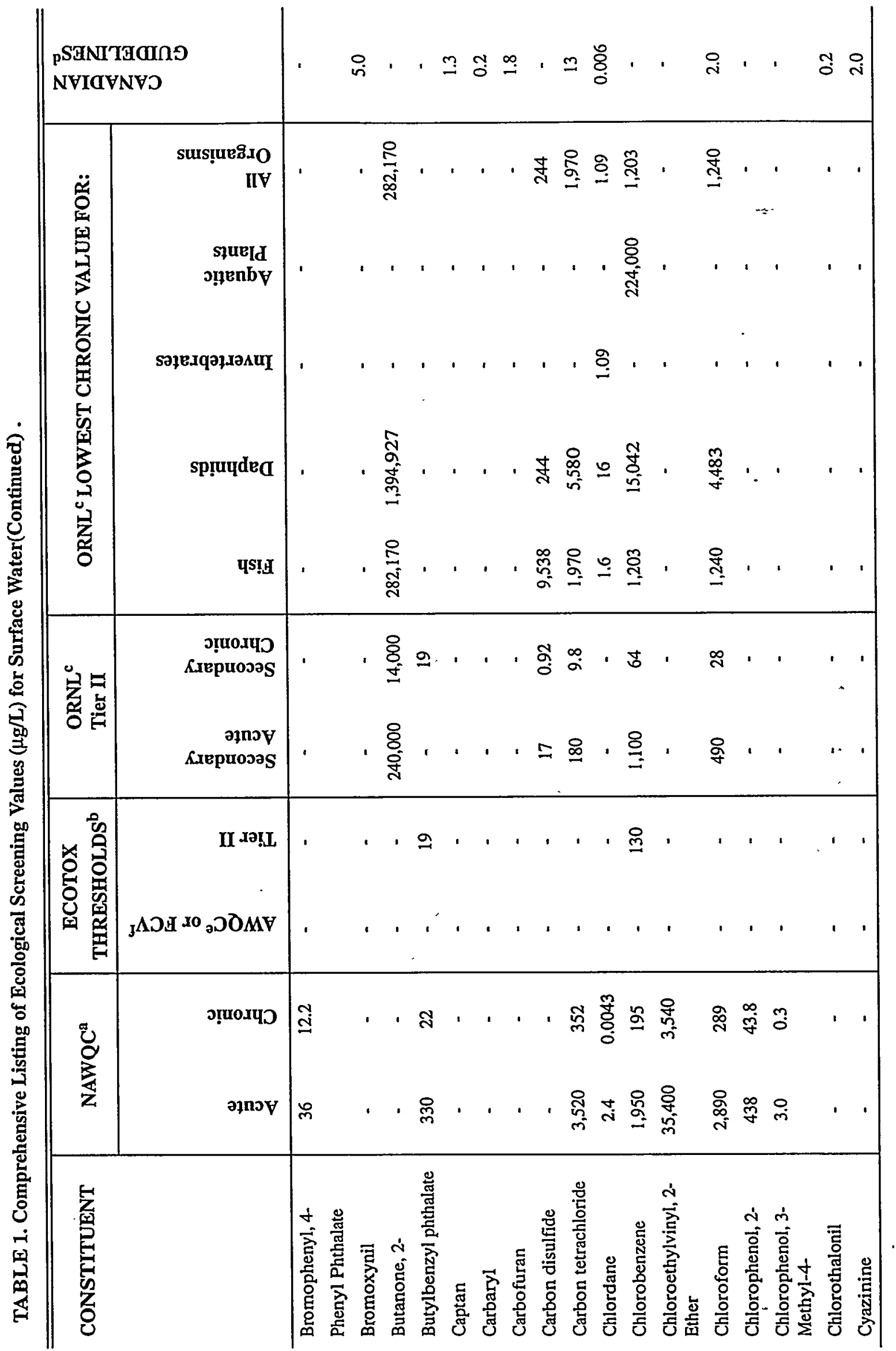




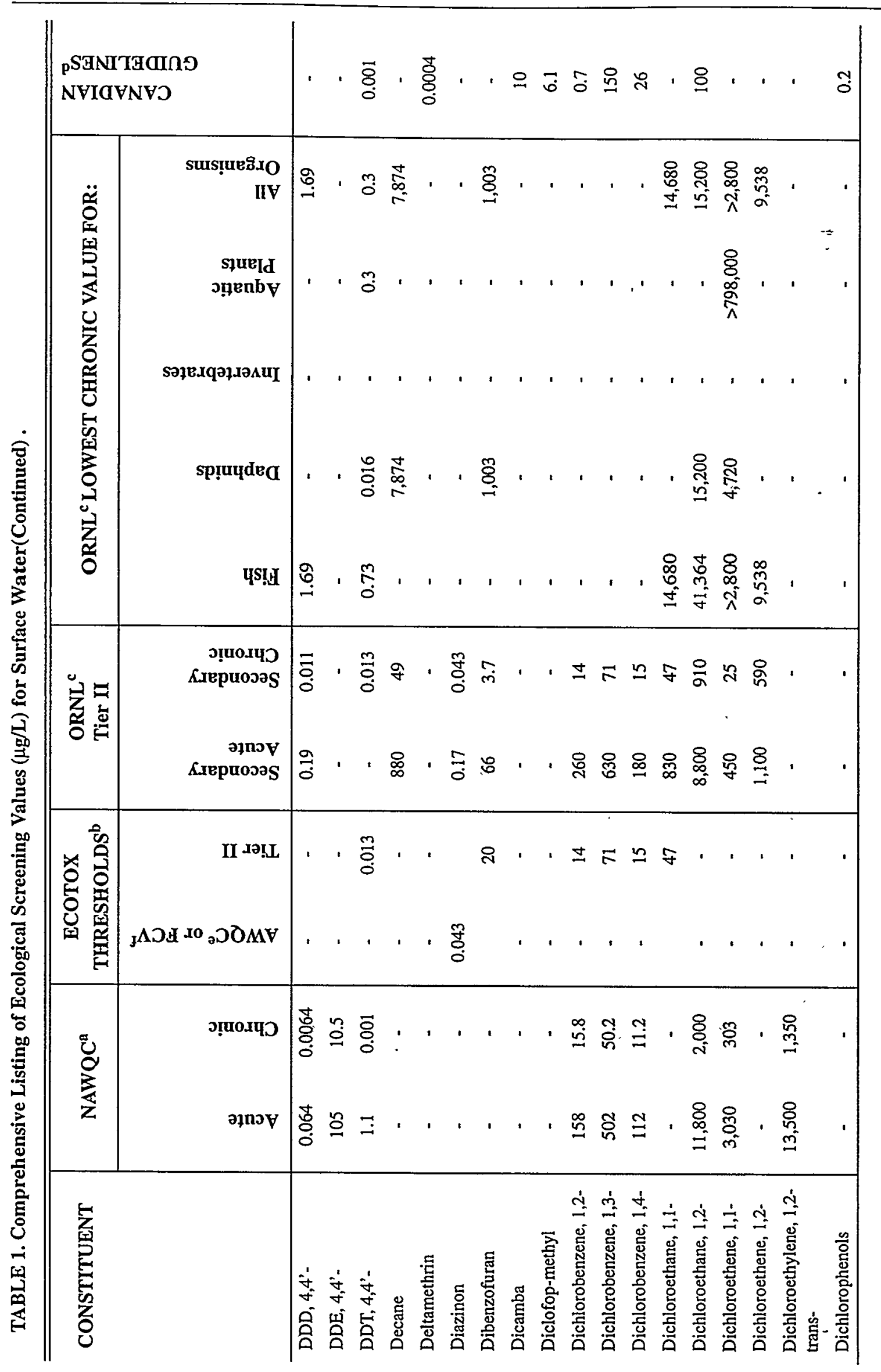




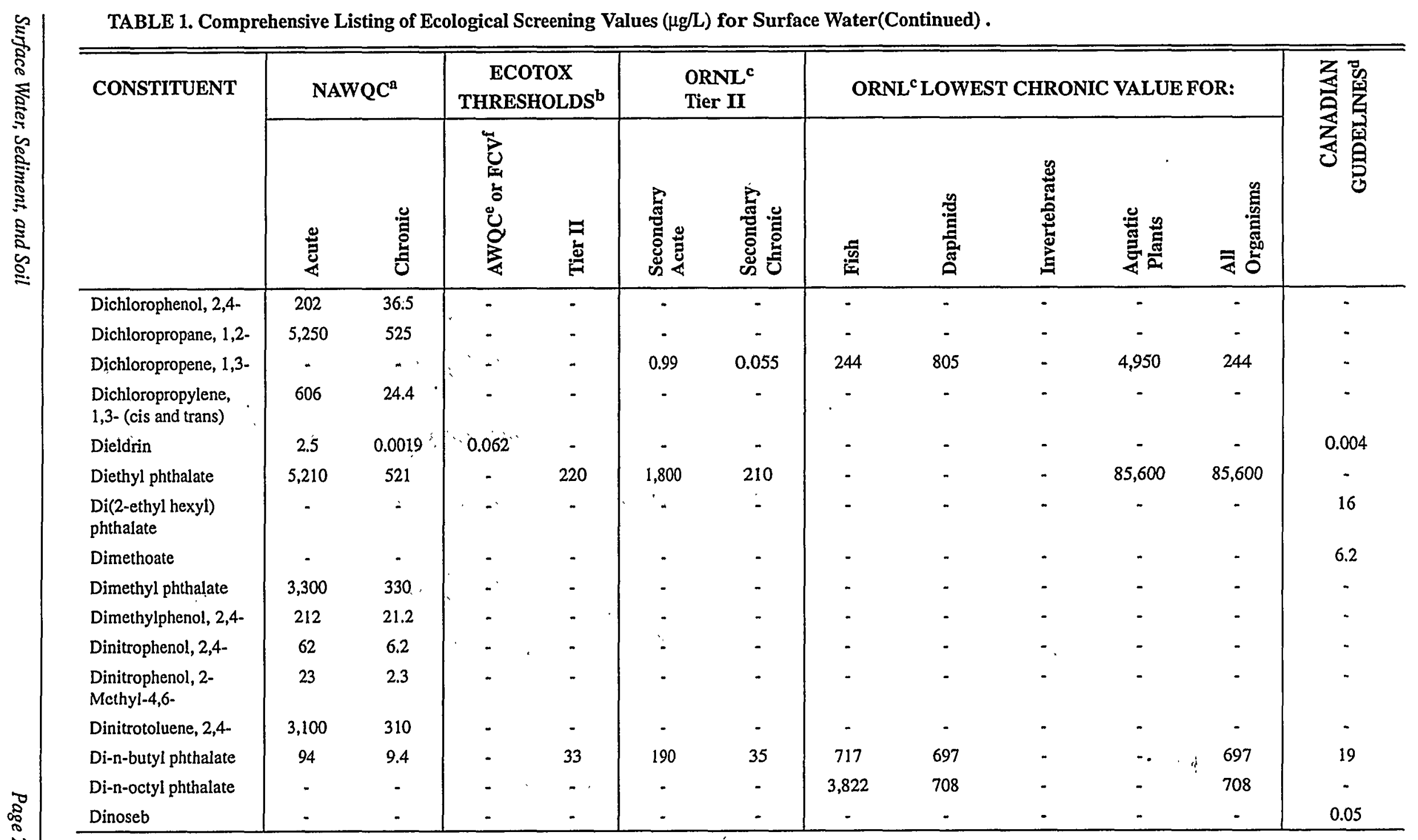




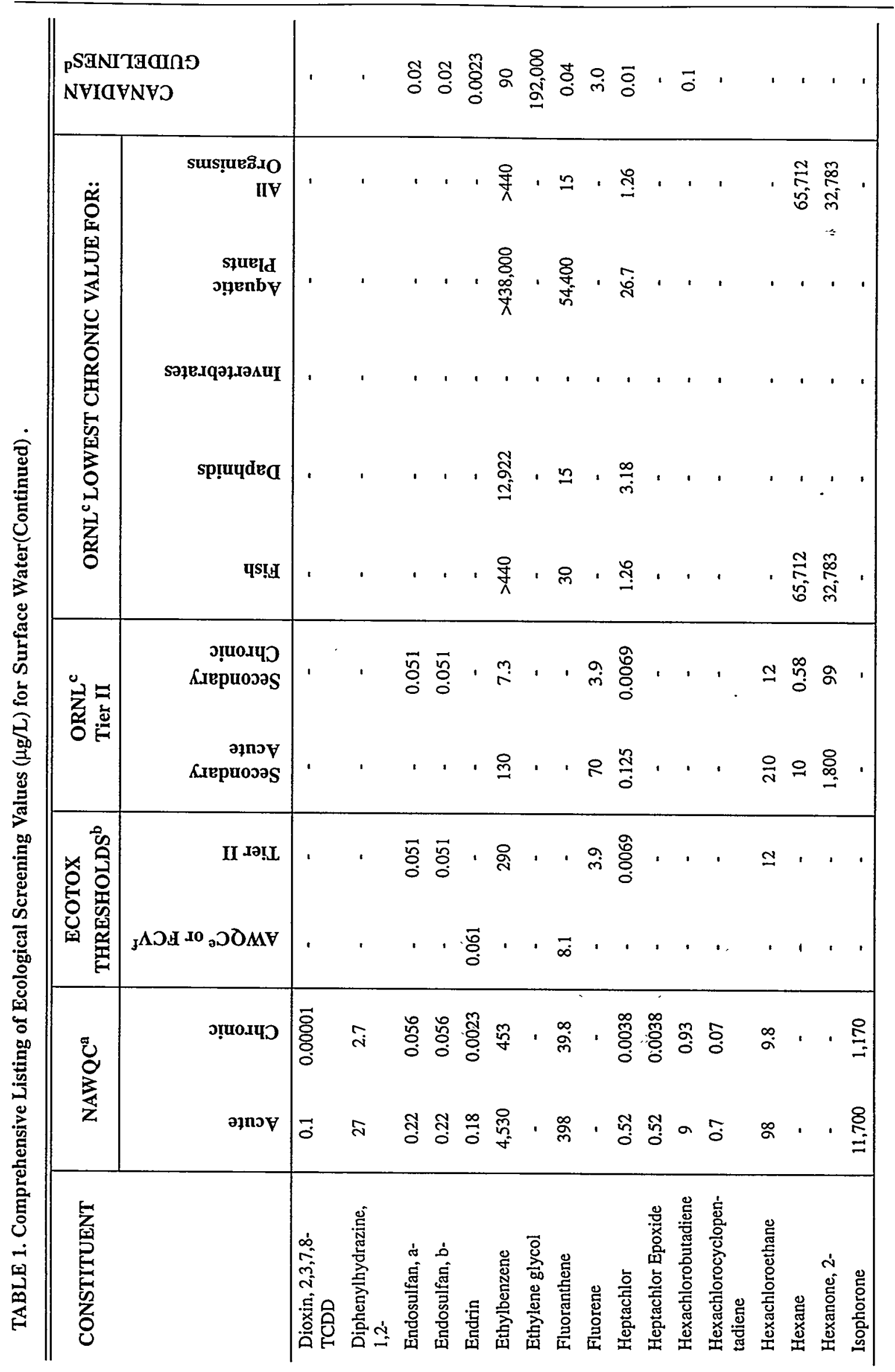




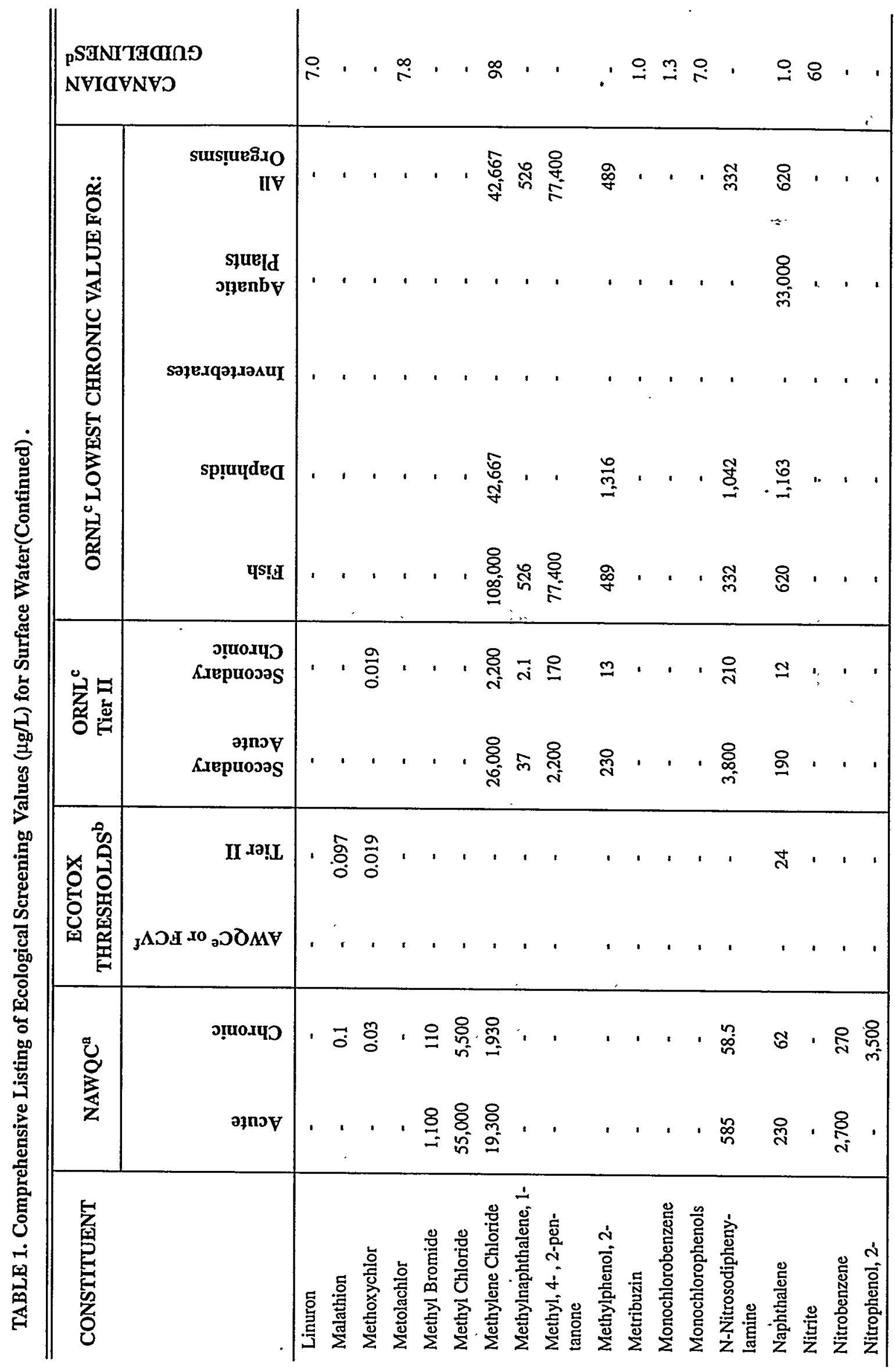




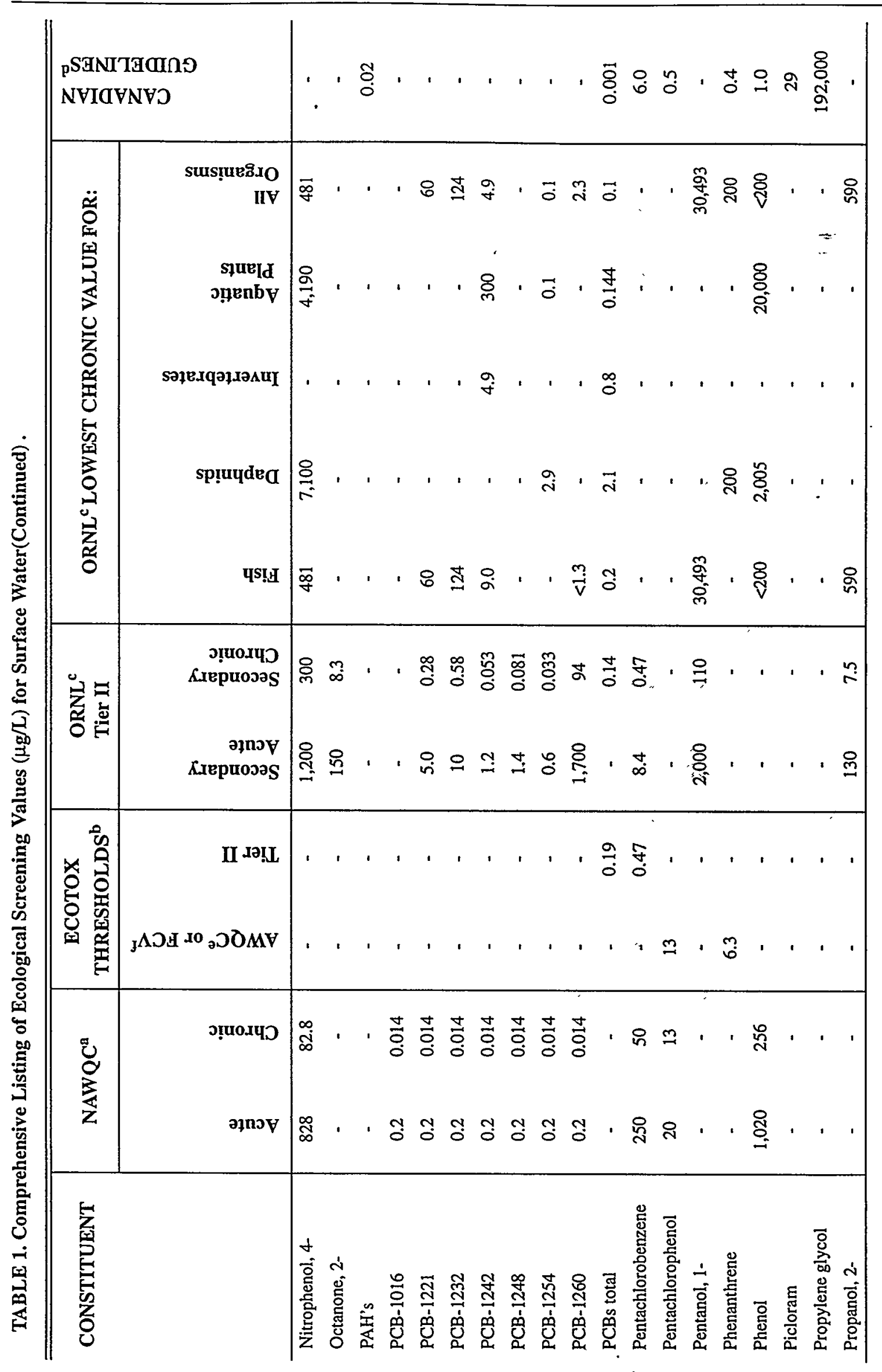




\begin{tabular}{|c|c|c|c|c|c|c|c|c|c|c|c|c|}
\hline \multirow[t]{2}{*}{ CONSTITUENT } & \multicolumn{2}{|c|}{ NAWQC ${ }^{\mathrm{a}}$} & \multicolumn{2}{|c|}{$\begin{array}{c}\text { ECOTOX } \\
\text { THRESHOLDS }^{\mathbf{b}}\end{array}$} & \multicolumn{2}{|c|}{$\begin{array}{l}\text { ORNLc } \\
\text { Tier II }\end{array}$} & \multicolumn{5}{|c|}{ ORNLC LOWEST CHRONIC VALUE FOR: } & \multirow{2}{*}{ 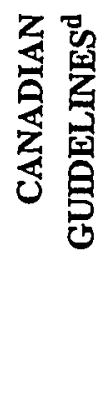 } \\
\hline & 这 & 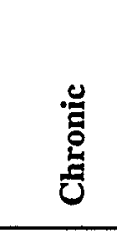 & 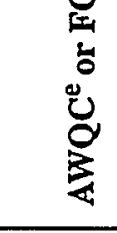 & $\stackrel{\bullet}{\mathscr{e}}$ & 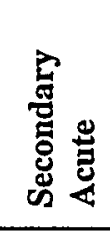 & 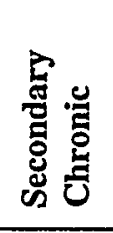 & 空 & 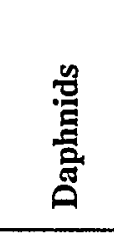 & 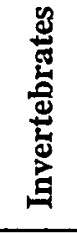 & 总葛 & 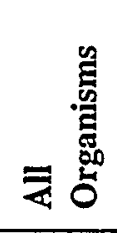 & \\
\hline Pyrene & - & - & - & - & - & - & - & - & - & - & - & 0.02 \\
\hline Quinoline & - & - & - & - & - & - & - & - & - & - & - & 3.0 \\
\hline Simazine & - & - & - & - & - & - & - & - & - & - & - & 10 \\
\hline Tebuthiuron & - & - & - & - & - & - & - & - & - & - & - & 1.6 \\
\hline $\begin{array}{l}\text { Tetrachlorobenzene, } \\
1,2,3,4\end{array}$ & - & - & - & - & - & - & - & - & - & $\cdot$ & - & 1.8 \\
\hline $\begin{array}{l}\text { Tetrachlorobenzene, } \\
1,2,4,5 \text { - }\end{array}$ & 250 & 50 & - & - & - & - & - & - & - & - & - & - \\
\hline $\begin{array}{l}\text { Tetrachloroethane, } \\
1,1,2,2-\end{array}$ & 932 & 240 & - & 420 & 2,100 & 610 & 2,400 & 9,900 & - & 136,000 & 2,400 & - \\
\hline Tetrachloroethene & 528 & 84 & - & 120 & 830 & 98 & 840 & 750 & - & $>816,000$ & 750 & 110 \\
\hline Tetrachloromethane & - & $\cdot$ & & 240 & 4,400 & 240 & - & - & - & - & - & - \\
\hline Tetrachlorophenols & - & - & - & $\cdot$ & - & - & - & - & - & - & - & 1.0 \\
\hline Toluene & 1,750 & 175. & - & 130 & 120 & 9.8 & 1,269 & 25,229 & - & 245,000 & 1,269 & 2.0 \\
\hline Toxaphene & 0.73 & 0.0002 & - & 0.011 & - & - & $\cdot$ & - & - & - & - & 0.008 \\
\hline Trialiate & - & - & - & $\cdot$ & - & - & - & - & - & - & - & 0.24 \\
\hline Tribromomethane & - & - & & 320 & 2,300 & 320 & - & - & - & - & - & - \\
\hline Tributyltin & - & 0.026 & - & - & - & - & - & - & - & - & - & 0.008 \\
\hline $\begin{array}{l}\text { Trichlorobenzene, } \\
1,2,3-\end{array}$ & - & $\cdot$ & - & - & - & - & - & - & - & - & - & 8.0 \\
\hline
\end{tabular}




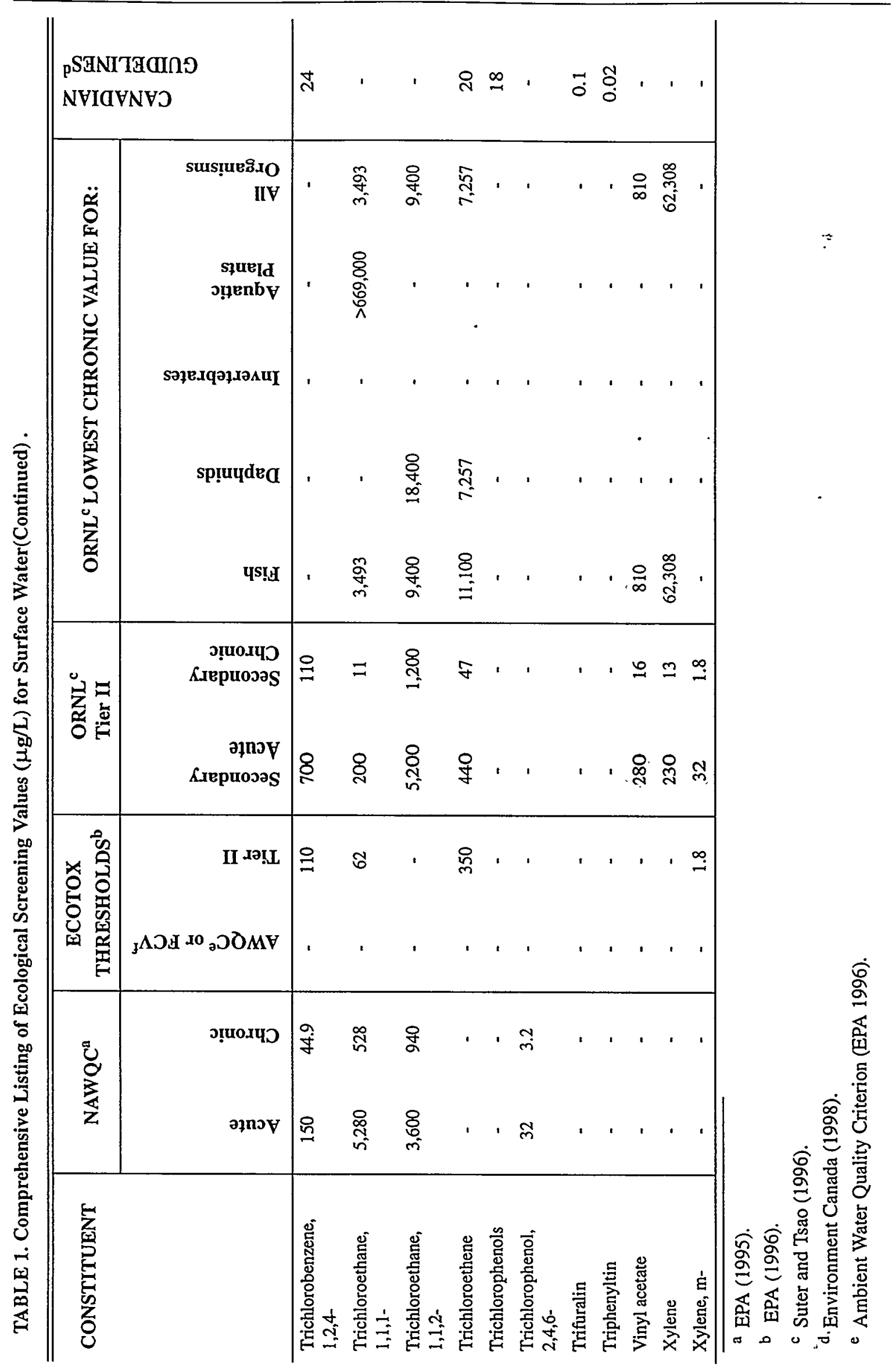




\begin{tabular}{|c|c|c|}
\hline \multicolumn{3}{|c|}{ f Final Chronic Value (EPA 1996). } \\
\hline \multirow{2}{*}{\multicolumn{3}{|c|}{$\begin{array}{l}{ }^{\mathrm{g}} \mathrm{pH} 6.5-9.0 \\
{ }_{\mathrm{h}} \mathrm{pH}<6.5 ;[\mathrm{Ca}+2]<4 \mathrm{mg} / \mathrm{L} ; \mathrm{DOC}<2.0 \mathrm{mg}\end{array}$}} \\
\hline & & \\
\hline \multicolumn{3}{|c|}{ i $\mathrm{pH} \geq 6.5 ;[\mathrm{Ca}+2]<4 \mathrm{mg} / \mathrm{L} ; \mathrm{DOC}<2.0 \mathrm{mg} / \mathrm{L}$} \\
\hline \multicolumn{3}{|c|}{${ }^{\mathrm{j}} \mathrm{pH} 8.0 ; 10^{\circ} \mathrm{C}$. } \\
\hline \multicolumn{3}{|c|}{${ }^{\mathrm{k}} \mathrm{pH} 6.5 ; 10^{\circ} \mathrm{C}$} \\
\hline \multirow{3}{*}{\multicolumn{3}{|c|}{$\begin{array}{l}{ }^{1} 2 \mu \mathrm{g} / \mathrm{L} \text { at } \mathrm{CaCO}_{3} 0-120 \mathrm{mg} / \mathrm{L} ; 3 \mu \mathrm{g} / \mathrm{L} \text { at } \mathrm{CaCO}_{3} 120-180 \mathrm{mg} / \mathrm{L} ; 4 \mu \mathrm{g} / \mathrm{L} \text { at } \\
\text { m } 1 \mu \mathrm{g} / \mathrm{L} \text { at } \mathrm{CaCO}_{3} 0-60 \mathrm{mg} / \mathrm{L} ; 2 \mu \mathrm{g} / \mathrm{L} \text { at } \mathrm{CaCO}_{3} 60-120 \mathrm{mg} / \mathrm{L} ; 4 \mu \mathrm{g} / \mathrm{L} \text { at } \mathrm{Ca} \\
\text { n } 25 \mu \mathrm{g} / \mathrm{L} \text { at } \mathrm{CaCO}_{3} 0-60 \mathrm{mg} / \mathrm{L} ; 65 \mu \mathrm{g} / \mathrm{L} \text { at } \mathrm{CaCO}_{3} 60-120 \mathrm{mg} / \mathrm{L} ; 110 \mu \mathrm{g} / \mathrm{L} \text { a }\end{array}$}} \\
\hline & & \\
\hline & & \\
\hline \multicolumn{3}{|c|}{ * NAWQC values based on hardness of $50 \mathrm{mg} / \mathrm{L} \mathrm{CaCO}$. Adjustments should use the $\mathrm{f}$} \\
\hline Constituent & Acute Screening Value & Chronic Screening Value \\
\hline Cadmium & $\mathrm{e}^{(1.128(\ln \mathrm{n}) \cdot 3.828)}$ & $\mathrm{e}^{(1.785(\operatorname{lnH})-3.49)}$ \\
\hline Chromium III & $\mathrm{e}^{(0.819(\ln H)+3.688)}$ & $\mathrm{e}^{(0.819(\ln \mathrm{H})+1.561)}$ \\
\hline Copper & $\mathrm{e}^{(0.9422(\ln \mathrm{H})-1.464)}$ & $\mathrm{e}^{(0.8545(\ln \mathrm{H})-1.465)}$ \\
\hline Lead & $\mathrm{e}^{(1.273(\ln H)-1.46)}$ & $\mathrm{e}^{(1.273(\ln \mathrm{H})-4.705)}$ \\
\hline Nickel & $\mathrm{e}^{(0.846(\ln \mathrm{H})+3.3612)}$ & $\mathrm{e}^{(0.846(\mathrm{ln} \mathrm{H})+1.1645)}$ \\
\hline Silver & $\mathrm{e}^{(1.72(\ln H) \cdot 6.52)}$ & \\
\hline Zinc & $\mathrm{e}^{(0.8473(\ln H)+8.8604)}$ & $\mathrm{e}^{(0.8473(\ln \mathrm{H})+0.7614}$ \\
\hline
\end{tabular}




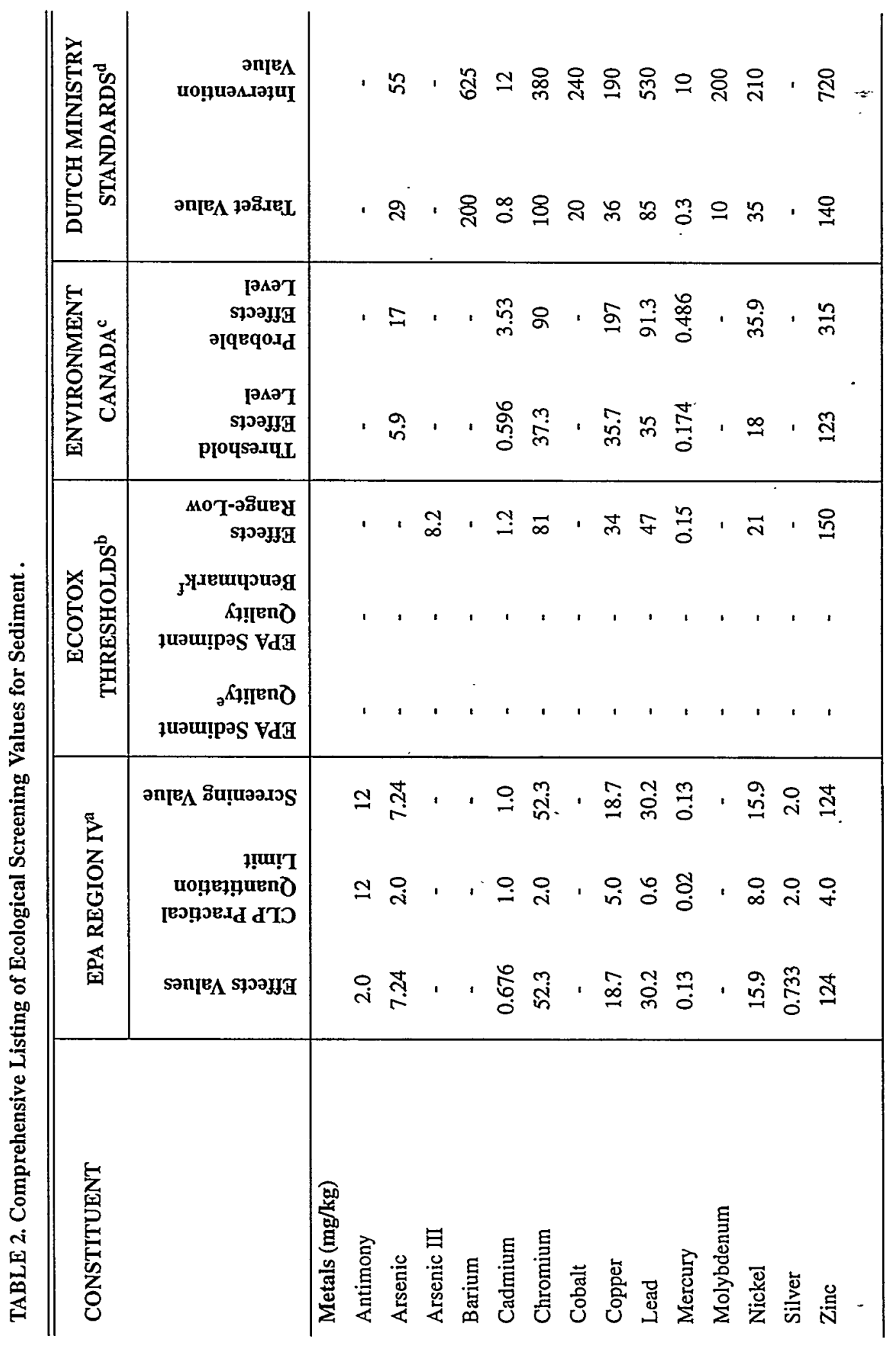




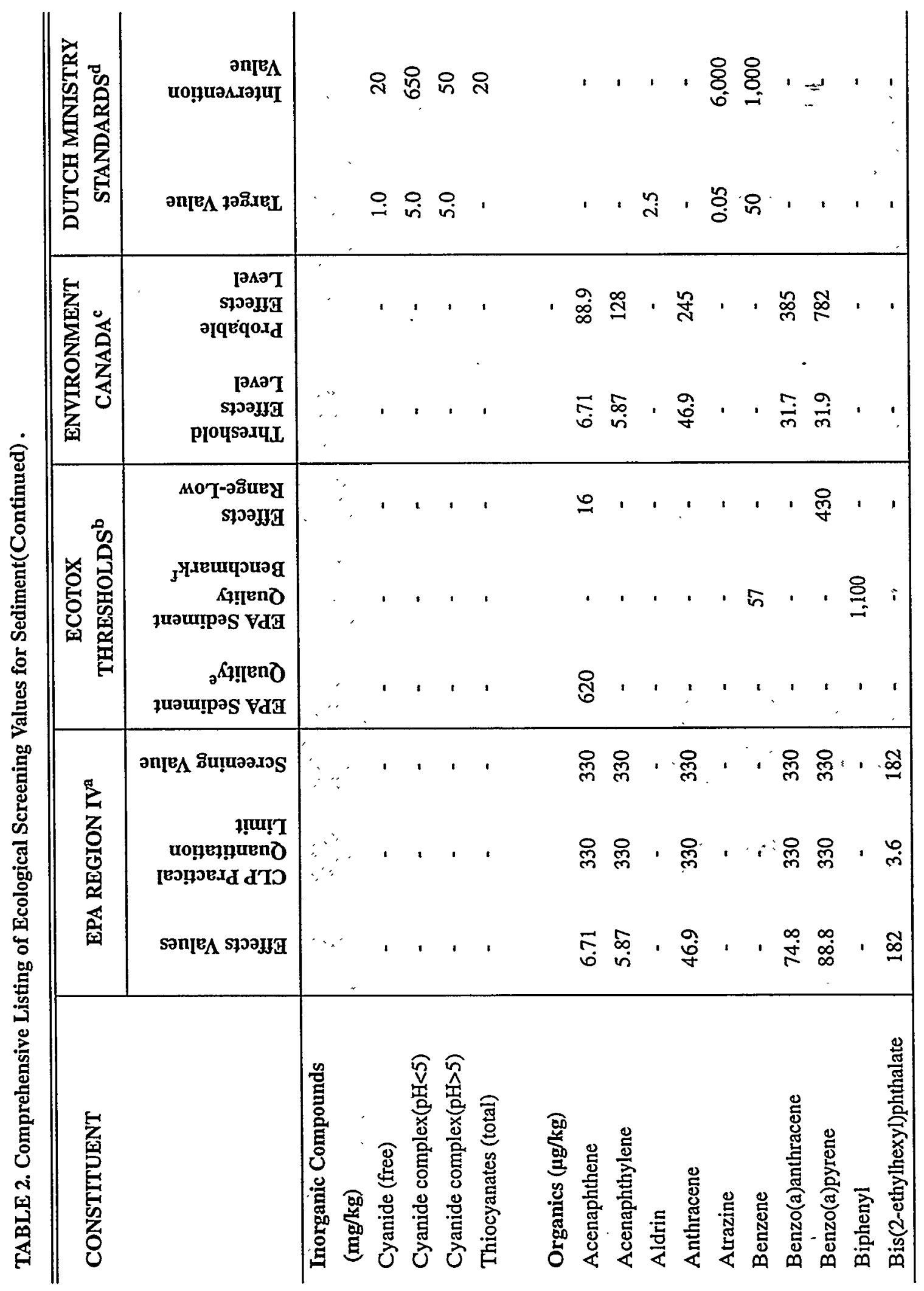




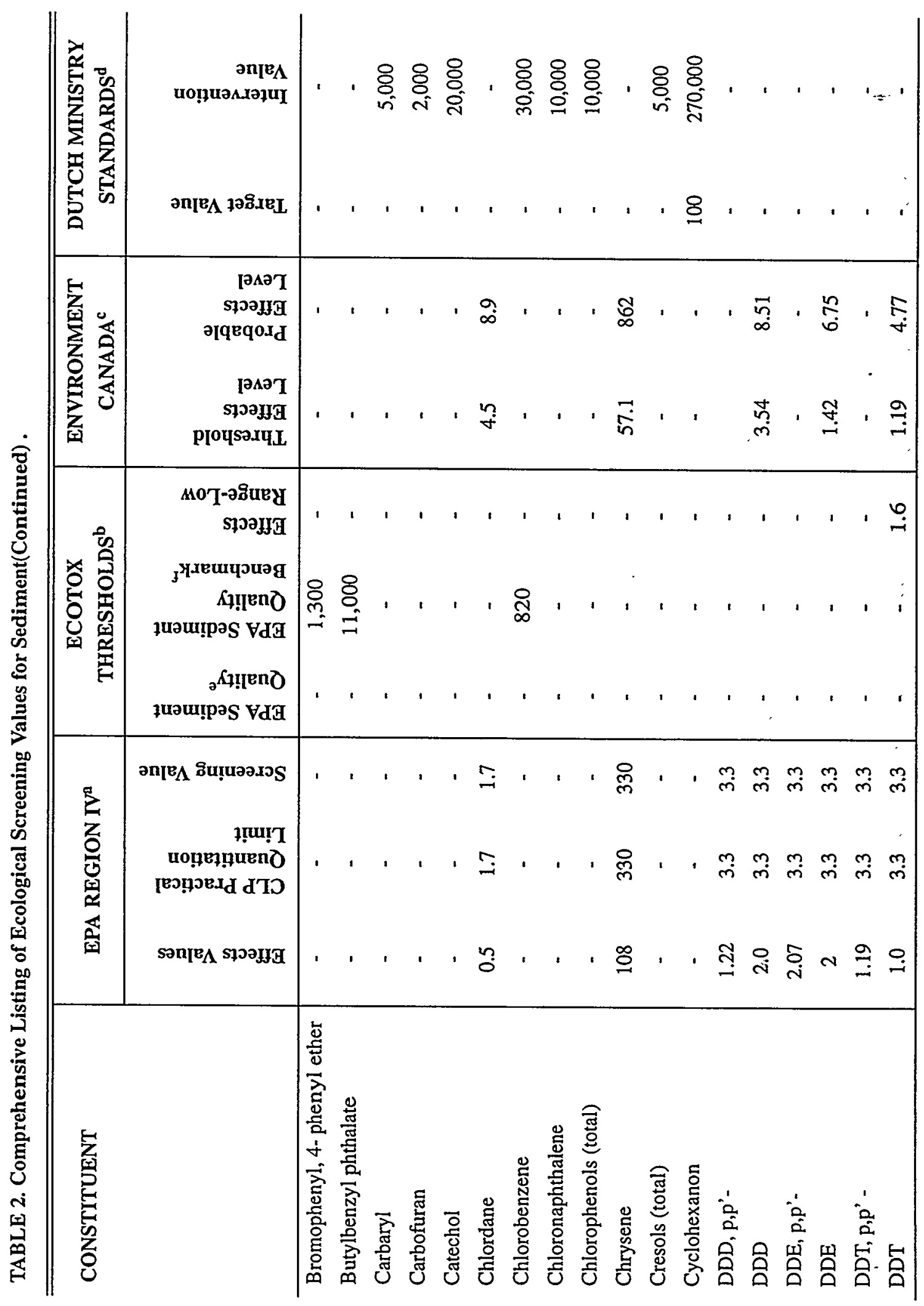




\begin{tabular}{|c|c|c|c|c|c|c|c|c|c|c|}
\hline \multirow[t]{2}{*}{ CONSTITUENT } & \multicolumn{3}{|c|}{ EPA REGION IV ${ }^{a}$} & \multicolumn{3}{|c|}{$\begin{array}{c}\text { ECOTOX } \\
\text { THRESHOLDS }^{b}\end{array}$} & \multicolumn{2}{|c|}{$\begin{array}{l}\text { ENVIRONMENT } \\
\text { CANADA }^{c}\end{array}$} & \multicolumn{2}{|c|}{$\begin{array}{l}\text { DUTCH MINISTRY } \\
\text { STANDARDS }^{d}\end{array}$} \\
\hline & 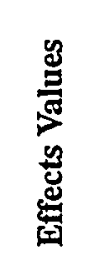 & 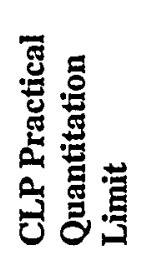 & 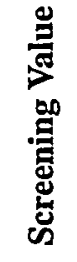 & 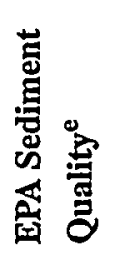 & 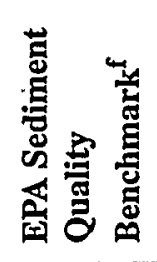 & 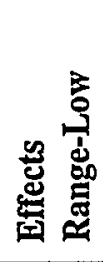 & 总 & 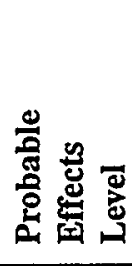 & 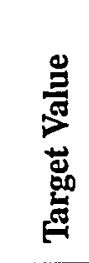 & 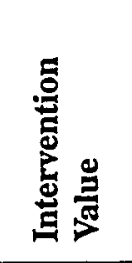 \\
\hline DDT (total) & 1.58 & 3.3 & 3.3 & - & - & - & - & - & - & - \\
\hline $\mathrm{DDT} / \mathrm{DDE} / \mathrm{DDD}$ (total) & - & - & - & - & - & - & - & - & 2.5 & 4,000 \\
\hline Diazinon & - & - & - & - & 1.9 & - & - & - & - & - \\
\hline Dibenzo(a,h)anthracene & 6.22 & 330 & 330 & - & - & - & 6.22 & 135 & - & - \\
\hline Dibenzofuran & - & - & - & - & 2,000 & - & - & - & - & - \\
\hline Dichlorobenzene, 1,2- & - & - & - & - & 340 & - & - & - & - & - \\
\hline Dichlorobenzene, 1,3- & - & - & - & - & 1,700 & - & - & - & - & - \\
\hline Dichlorobenzene, 1,4- & - & - & - & - & 350 & - & - & - & - & - \\
\hline Dichlorobenzene (total) & - & - & - & - & - & - & - & - & 10 & - \\
\hline Dichloroethane, 1,2- & - & - & - & - & - & - & - & - & - & 4,000 \\
\hline Dichloromethane & - & - & - & - & - & - & - & - & - & 20,000 \\
\hline Dichlorophenols (total) & - & - & $\therefore$ & - & - & - & - & - & 3.0 & - \\
\hline Dieldrin & 0.02 & 3.3 & 3.3 & 52 & - & - & 2.85 & 6.67 & 0.5 & - \\
\hline Diethyl phthalate & - & $-\cdots$ & - & - & 630 & - & - & - & - & - \\
\hline Di-n-butyl phthalate & - & - & - & - & 11,000 & - & - & - & - & - \\
\hline Endosulfan, mixed isomers & - & - & - & - & 5.4 & - & - & - & - & \&- \\
\hline Endosulfan, alpha & - & - & - & - & 2.9 & - & - & - & - & - \\
\hline Endosulfan, beta & - & - & - & - & 14 & - & - & - & - & - \\
\hline Endrin & 0.02 & 3.3 & 3.3 & 20 & - & - & 2.67 & 62.4 & 1.0 & - \\
\hline
\end{tabular}




\begin{tabular}{|c|c|c|c|c|c|c|c|c|c|c|}
\hline \multirow[t]{2}{*}{ CONSTITUENT } & \multicolumn{3}{|c|}{ EPA REGION IVa } & \multicolumn{3}{|c|}{$\begin{array}{c}\text { ECOTOX } \\
\text { THRESHOLDS }^{b}\end{array}$} & \multicolumn{2}{|c|}{$\begin{array}{l}\text { ENVIRONMENT } \\
\text { CANADA }^{c}\end{array}$} & \multicolumn{2}{|c|}{$\begin{array}{l}\text { DUTCH MINISTRY } \\
\text { STANDARDS }^{d}\end{array}$} \\
\hline & 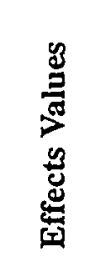 & 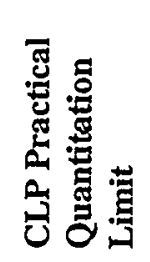 & 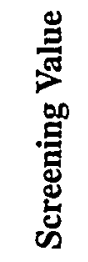 & 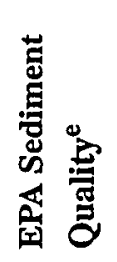 & 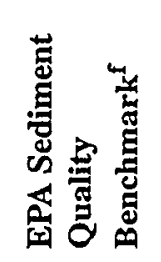 & 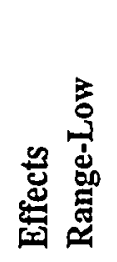 & 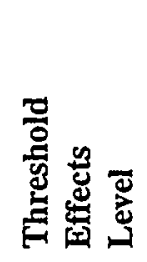 & 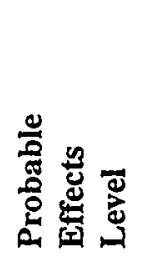 & 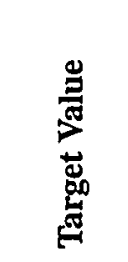 & 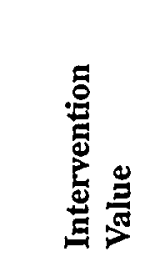 \\
\hline Ethylbenzene & - & - & - & - & 3,600 & - & - & - & 50 & 50,000 \\
\hline Fluoranthene & 113 & 330 & 330 & 2,900 & - & 600 & 111 & 2,355 & - & - \\
\hline Fluorene & 21.2 & 330 & 330 & - & 540 & - & 21.2 & 144 & - & - \\
\hline $\mathrm{a}-\mathrm{HCH}$ & - & - & - & - & - & - & - & - & 2.5 & - \\
\hline b-HCH & - & - & - & - & - & - & - & - & 1.0 & - \\
\hline $\mathrm{g}-\mathrm{HCH}$ (Lindane) & 0.32 & 3.3 & 3.3 & - & 3.7 & - & 0.94 & 1.38 & 0.05 & - \\
\hline Heptachlor epoxide & $\therefore$ & - & 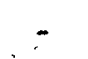 & - & .. & - & 0.6 & 2.74 & - & - \\
\hline Hexachlorobenzene & - & - & - & - & - & - & - & - & 2.5 & - \\
\hline Hexachloroethane & - & - & - & - & 1,000 & - & - & - & - & - \\
\hline Hydrochinon & - & - & - & - & - & - & - & - & - & 10,000 \\
\hline Malathion & - & - & - & - & 0.67 & - & - & - & - & - \\
\hline Maneb & - & - & - & - & - & - & - & - & - & 35,000 \\
\hline Methyl, 2- Naphthalene & 20.2 & 330 & 330 & - & - & - & 20.2 & 201 & - & - \\
\hline Methoxychlor & - & - & - & - & 19 & - & - & - & - & - \\
\hline Mineral Oil & - & - & - & - & - & - & - & - & 50,000 & $5,000,000$ \\
\hline Monochlorophenols (total) & - & - & - & - & - & - & - & - & 2.5 & - \\
\hline Naphthalene & 34.6 & 330 & 330 & - & 480 & 160 & 34.6 & 391 & - & $10^{-}$ \\
\hline PCB (Aroclor 1221) & 21.6 & 67 & 67 & - & - & - & - & - & - & - \\
\hline PCB (Aroclor 1254) & - & - & - & - & - & - & 60 & 340 & - & - \\
\hline PCBs (Total) & 21.6 & 33 & 33 & - & $\therefore$ & 23 & 34.1 & 277 & 20 & 1,000 \\
\hline
\end{tabular}




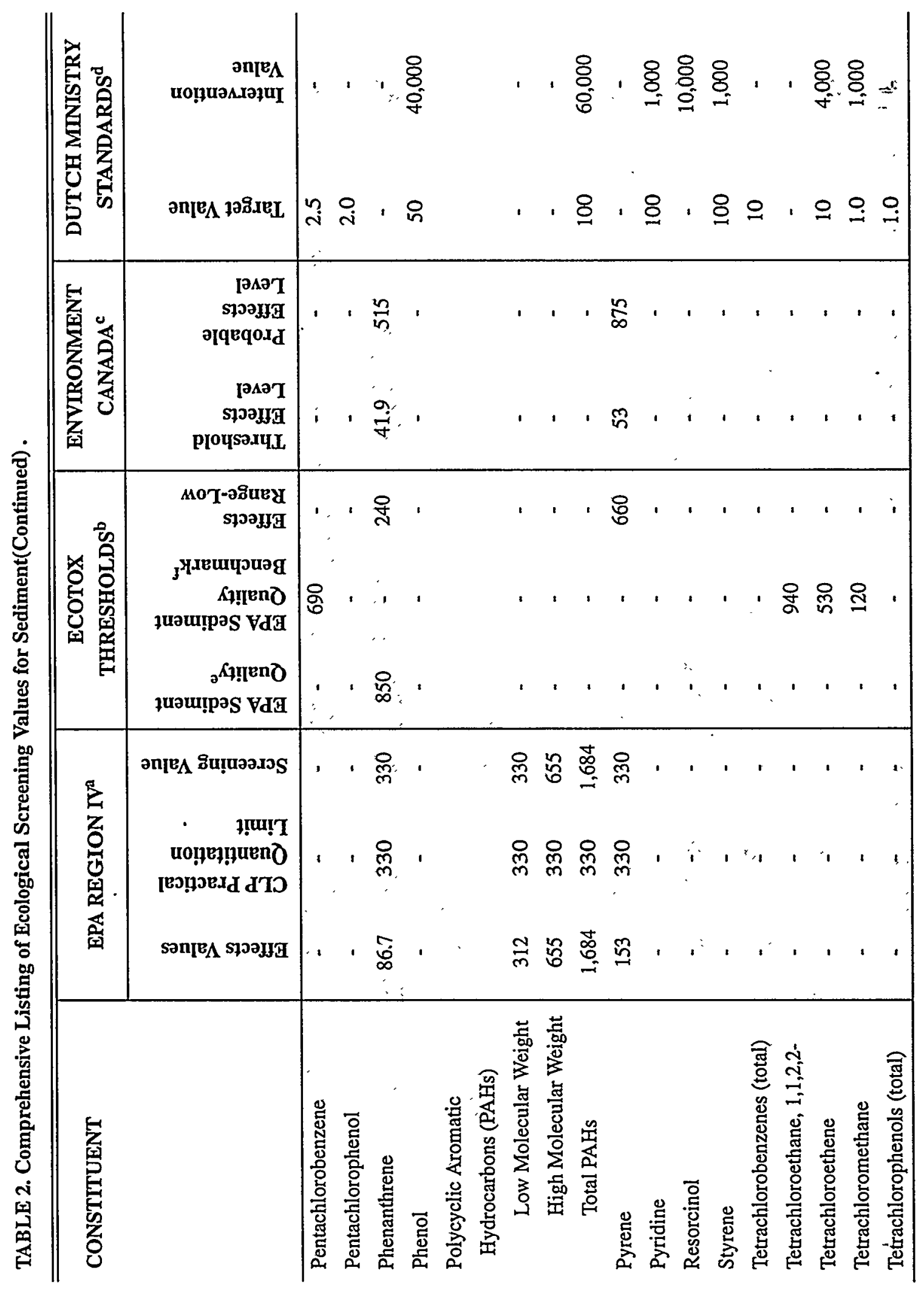




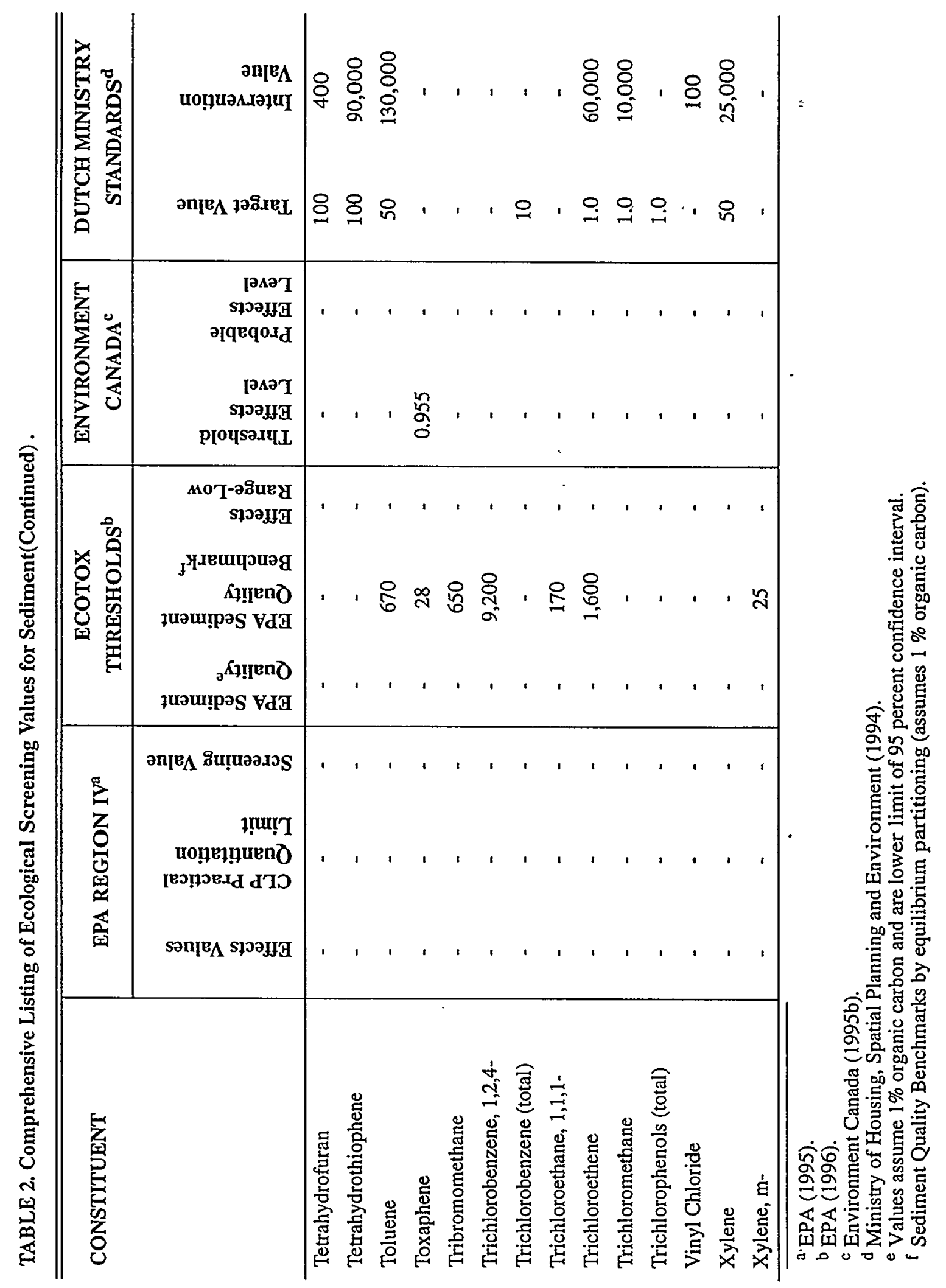




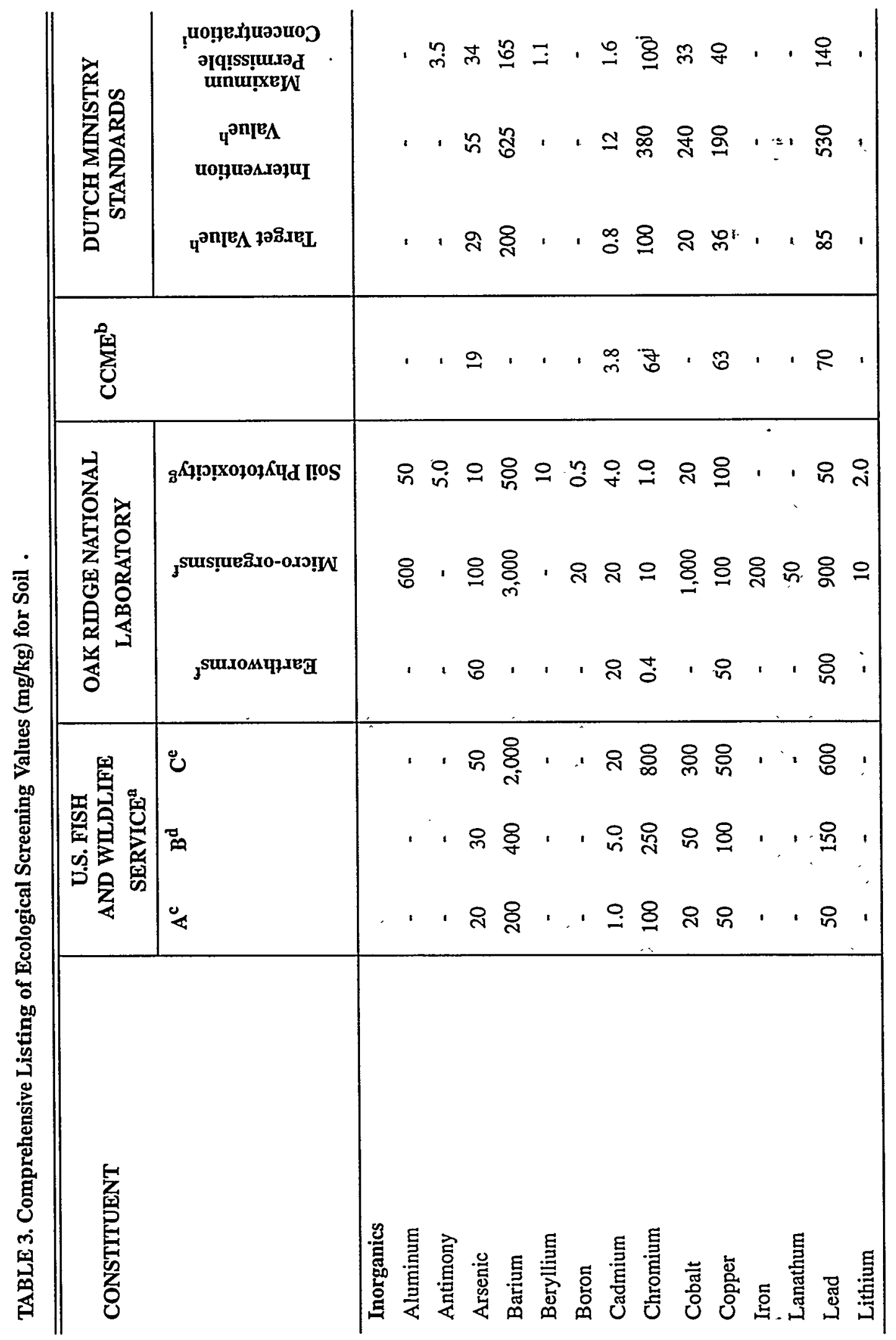




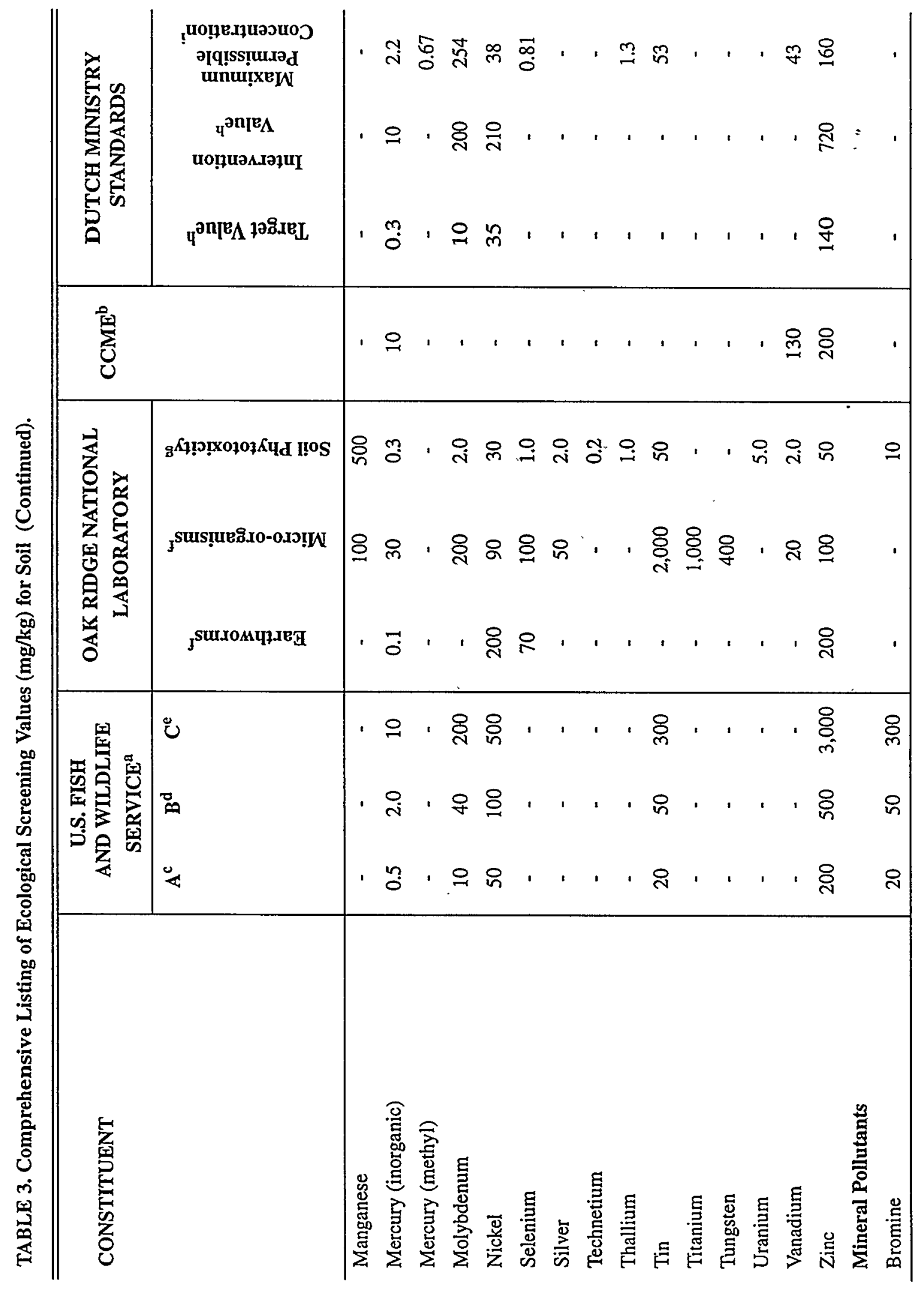




\begin{tabular}{|c|c|c|c|c|c|c|c|c|c|c|c|c|c|c|c|c|}
\hline 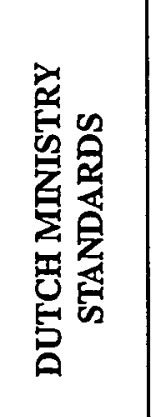 & 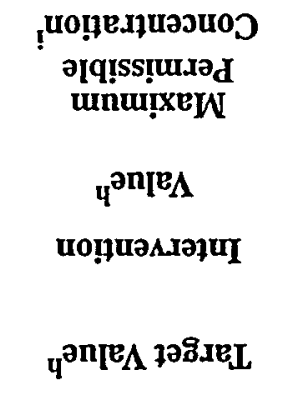 & $\mid$\begin{tabular}{ll}
1 & 1 \\
0 & 1 \\
\hdashline & 1
\end{tabular} & 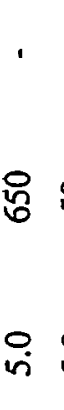 & $\begin{array}{l}1 \\
\text { 는 } \\
0 \\
\text { in }\end{array}$ & 요 & $\begin{array}{l}\prime \\
.\end{array}$ & ' & ' & & $\begin{array}{l}\stackrel{0}{-} \\
\stackrel{0}{0} \\
\stackrel{0}{0}\end{array}$ & ' & 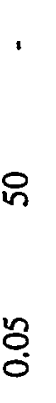 & \begin{tabular}{l} 
吕= \\
$\qquad$ \\
\hdashline \\
0
\end{tabular} & $\begin{array}{l}\overline{8} \\
\dot{0} \\
\dot{0}\end{array}$ & "2. & ' \\
\hline \multicolumn{2}{|l|}{$\sum_{0}^{0}$} & ఏે 1 & ' & ' & 1 & ' & ' & ' & & $\stackrel{\circ}{n}$ & ' & $\stackrel{-}{\Im}$ & $\stackrel{\Xi}{\longrightarrow}$ & 官 & $\stackrel{0}{-}$ & ' \\
\hline 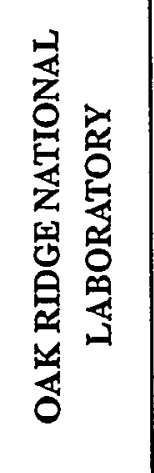 & 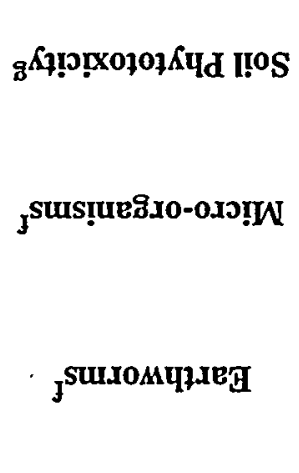 & $\begin{array}{l}\cdot 1 \\
. \quad 1 \\
.1\end{array}$ & ' & $\begin{array}{l}\prime \\
\text { ' }\end{array}$ & ' & $\begin{array}{l}\text { ్్ㅇ } \\
\text { 요 }\end{array}$ & $\underset{+}{\stackrel{0}{*}}$ & • & & ' & , & ' & ' & ' & ' &. \\
\hline 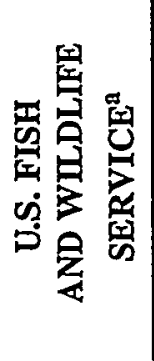 & $\begin{array}{l}0 \\
0\end{array}$ & $\begin{array}{ll}8 & 8 \\
-1 & 0 \\
& 0 \\
& n \\
& 0\end{array}$ & $\begin{array}{l}. \\
. \\
.\end{array}$ & $\begin{array}{l}\cdot \\
. \\
.\end{array}$ & ' & 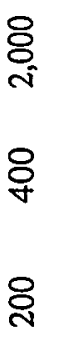 & ' & $\begin{array}{l}\text { ్ㅗ } \\
\text { ㅇ } \\
\text { i }\end{array}$ & & $\begin{array}{l}\stackrel{0}{n} \\
\ddot{0} \\
\ddot{0}\end{array}$ & $\begin{array}{l}. \\
. \\
\text { ' }\end{array}$ & 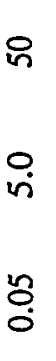 & $\begin{array}{l}\stackrel{p}{ } \\
\circ \\
\dot{m} \\
\ddot{0}\end{array}$ & ' & 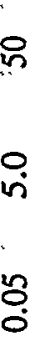 & $\begin{array}{l}P \\
0 \\
i \\
0\end{array}$ \\
\hline 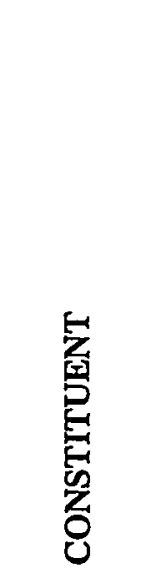 & & 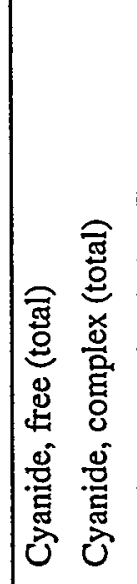 & 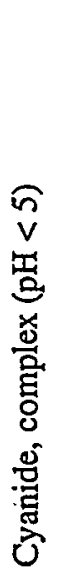 & 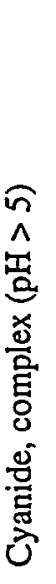 & לֶ. & 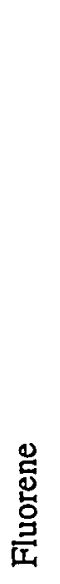 & & $\frac{\breve{s}}{5}$ & 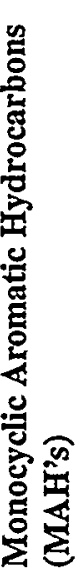 & 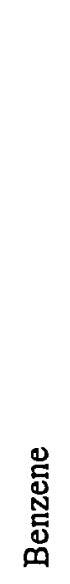 & 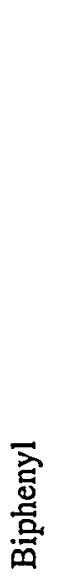 & 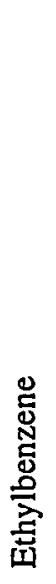 & & 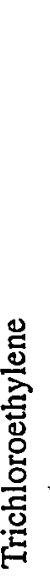 & & 焉 \\
\hline
\end{tabular}




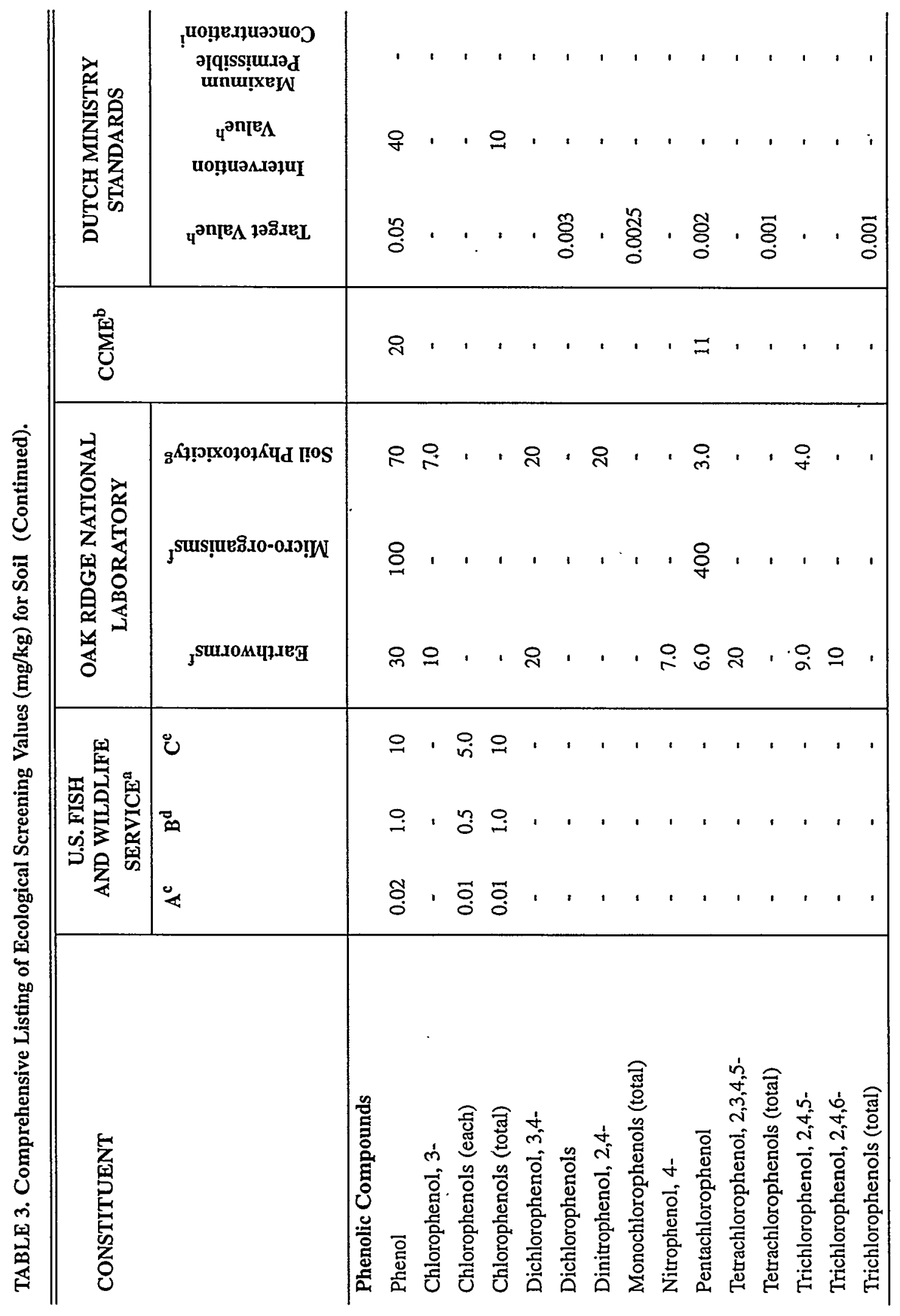




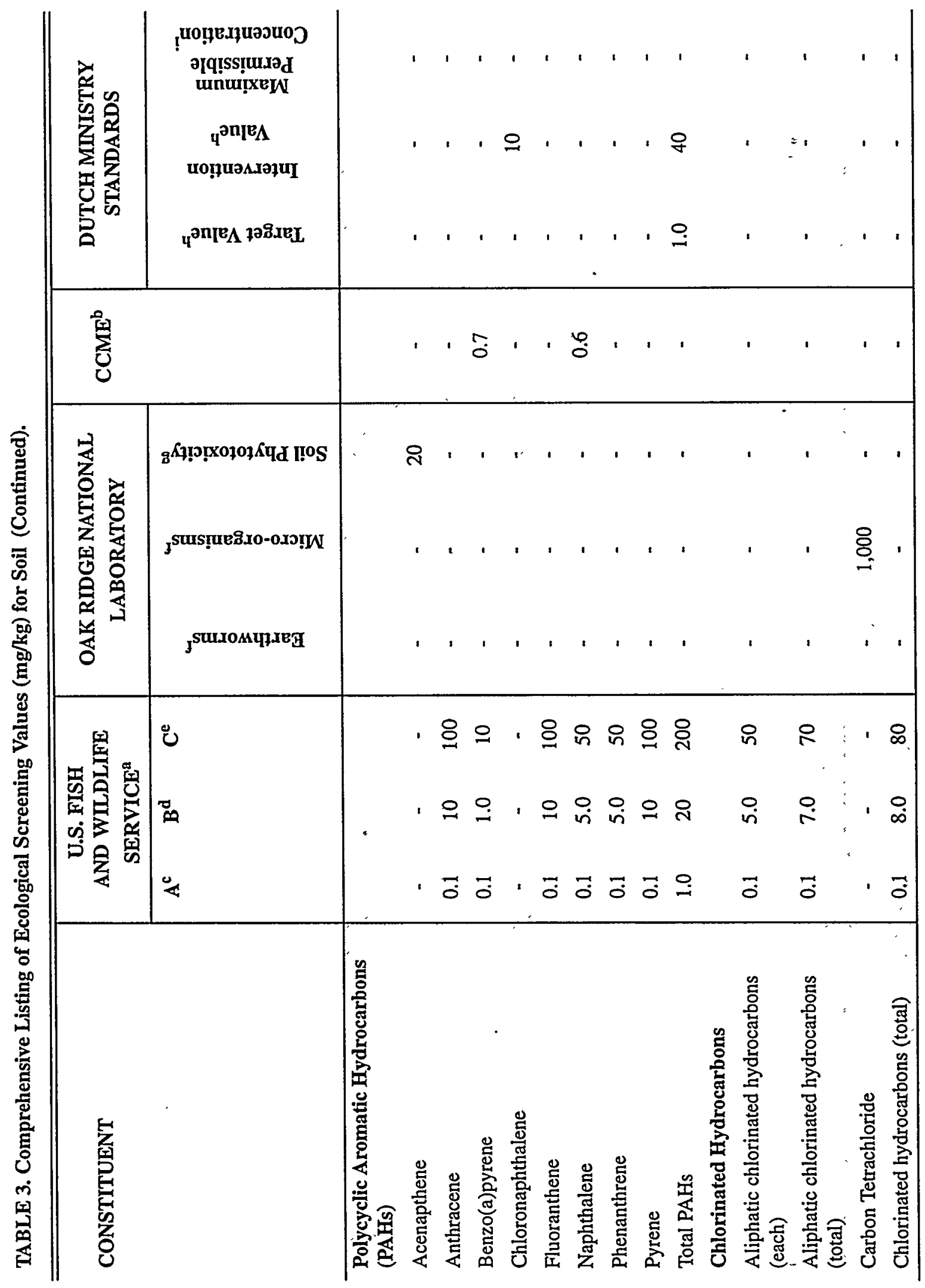




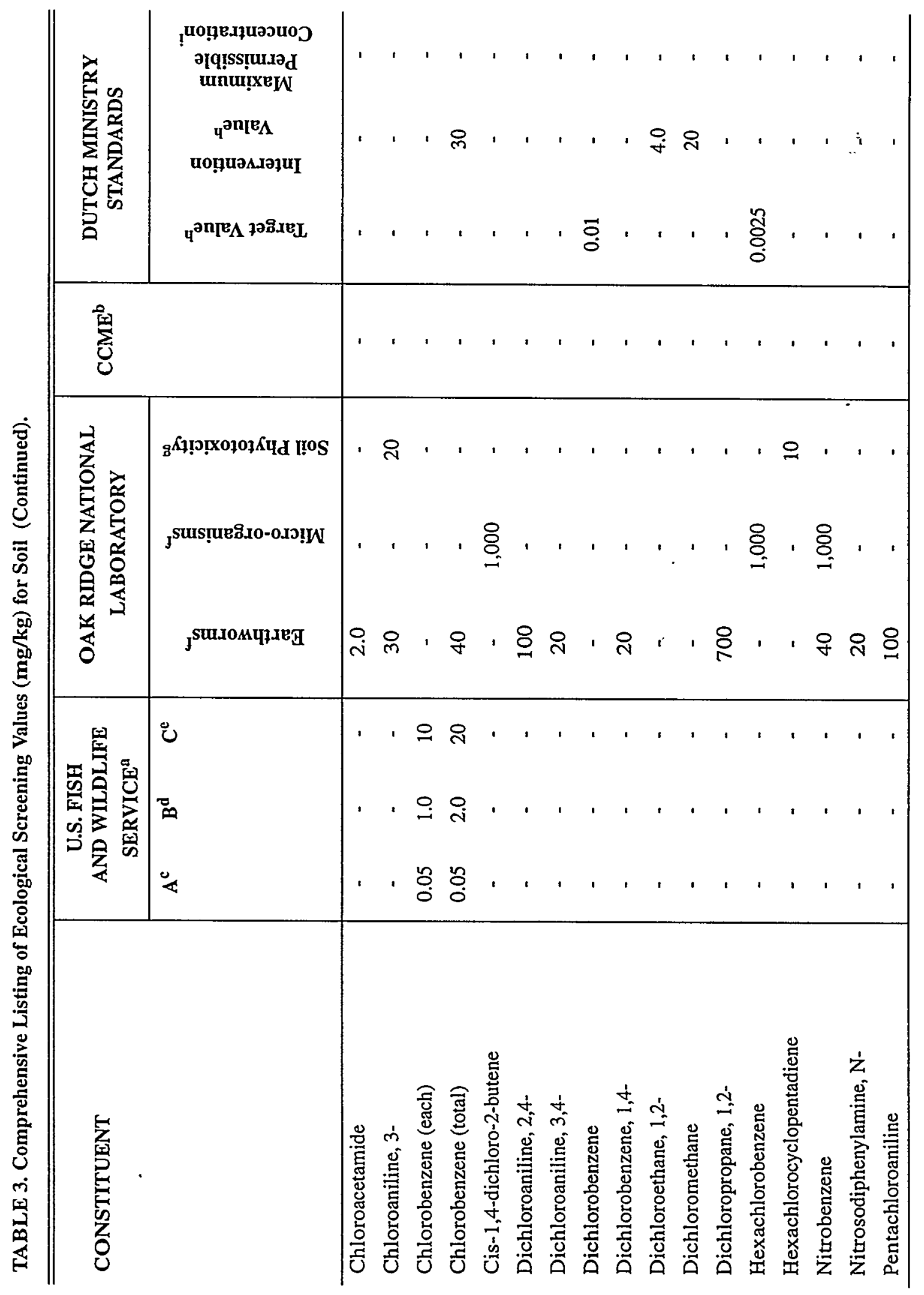




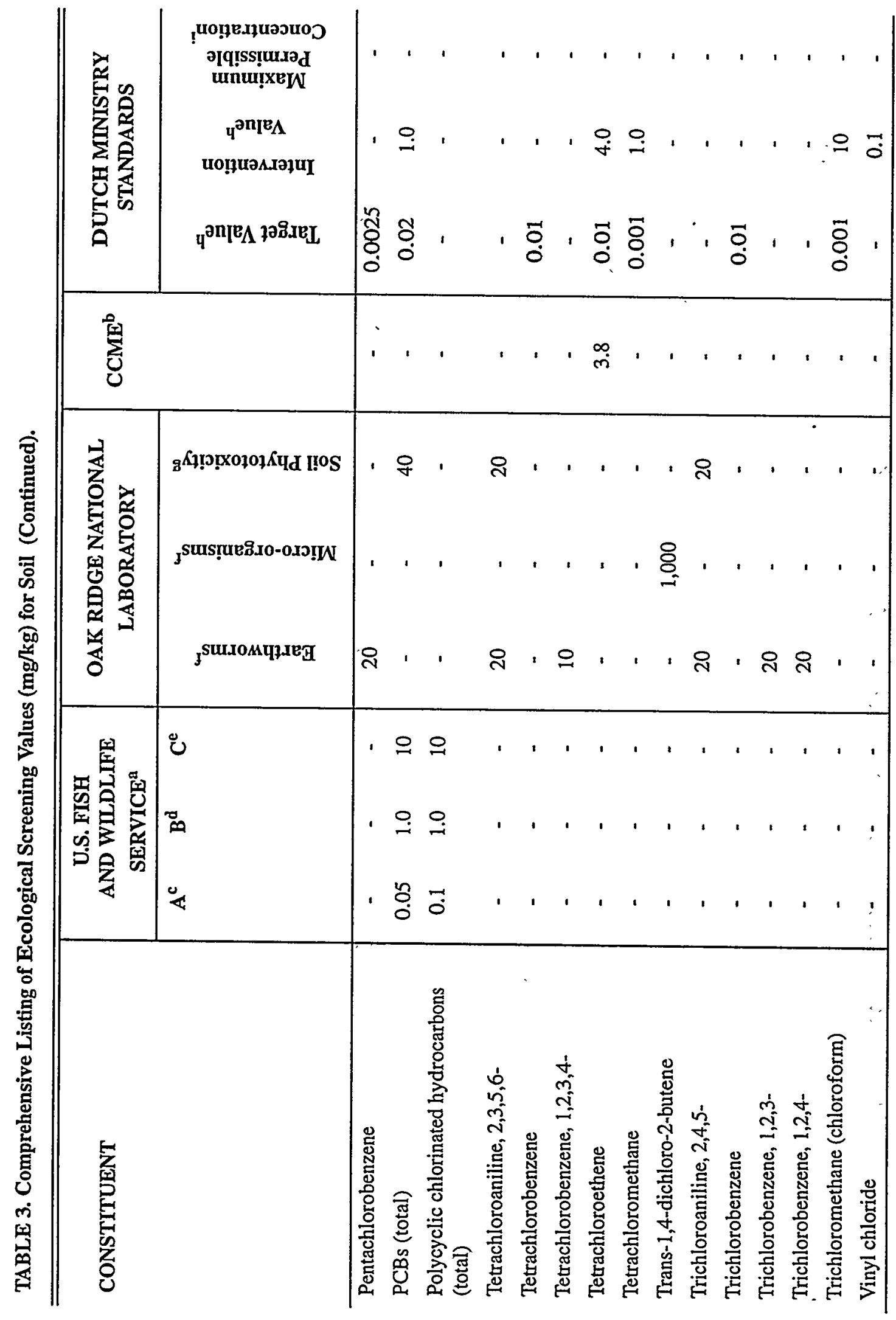


TABLE 3. Comprehensive Listing of Ecological Screening Values ( $\mathrm{mg} / \mathrm{kg}$ ) for Soil (Continued).

\begin{tabular}{|c|c|c|c|c|c|c|c|c|c|c|c|}
\hline \multirow[t]{2}{*}{ CONSTITUENT } & \multicolumn{3}{|c|}{$\begin{array}{l}\text { U.S. FISH } \\
\text { AND WILDLIFE } \\
\text { SERVICE }^{\mathfrak{a}}\end{array}$} & \multicolumn{3}{|c|}{$\begin{array}{l}\text { OAK RIDGE NATIONAL } \\
\text { LABORATORY }\end{array}$} & \multirow[t]{2}{*}{$\mathrm{CCME}^{\mathrm{b}}$} & \multicolumn{4}{|c|}{$\begin{array}{l}\text { DUTCH MINISTRY } \\
\text { STANDARDS }\end{array}$} \\
\hline & & & $\mathbf{C}^{\mathrm{e}}$ & 骂 & 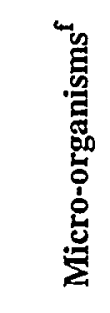 & 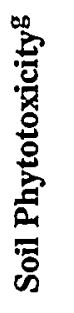 & & 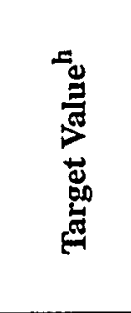 & 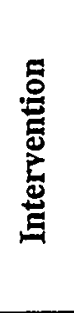 & 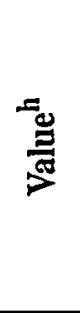 & 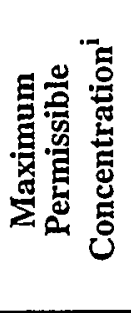 \\
\hline \multicolumn{12}{|l|}{ Pesticides } \\
\hline Aldrin & - & - & - & - & - & - & - & 0.0025 & & - & - \\
\hline Atrazine & - & - & - & - & - & - & - & 0.00005 & & 6.0 & - \\
\hline Carbaryl & - & - & - & - & - & - & - & - & & 5.0 & - \\
\hline Carbofuran & - & - & - & - & - & - & - & - & & 2.0 & - \\
\hline DDT/DDE/DDD & - & - & - & - & - & - & - & 0.0025 & & 4.0 & - \\
\hline Dieldrin & - & - & - & - & - & - & - & 0.0005 & & - & - \\
\hline Endrin & - & - & - & - & - & - & - & 0.001 & & - & - \\
\hline $\mathrm{a}-\mathrm{HCH}$ & - & - & - & - & - & - & - & 0.0025 & & - & - \\
\hline b-HCH & - & - & - & - & - & - & - & 0.001 & & - & $-\cdot$ \\
\hline $\mathrm{g}-\mathrm{HCH}$ (Lindane) & - & - & - & - & - & - & - & 0.00005 & & - & - \\
\hline Maneb & - & - & - & $\because$ & - & - & - & - & & 35 & - \\
\hline Organochlorinated (each) & 0.1 & 0.5 & 5.0 & - & - & - & - & - & & - & - \\
\hline Organochlorinated (total) & 0.1 & 1.0 & 10 & - & - & - & - & - & & - & - \\
\hline Total Pesticides & 0.1 & 2.0 & 20 & - & - & - & - & - & & - & - \\
\hline Other Pollutants & & . & & & & & & & & : & \\
\hline Acrylonitrile & - & - & - & - & 1,000 & - & - & - & & - & $\cdot$ \\
\hline Catechol & - & - & - &.- & - & - & - & - & & 20 & - \\
\hline
\end{tabular}




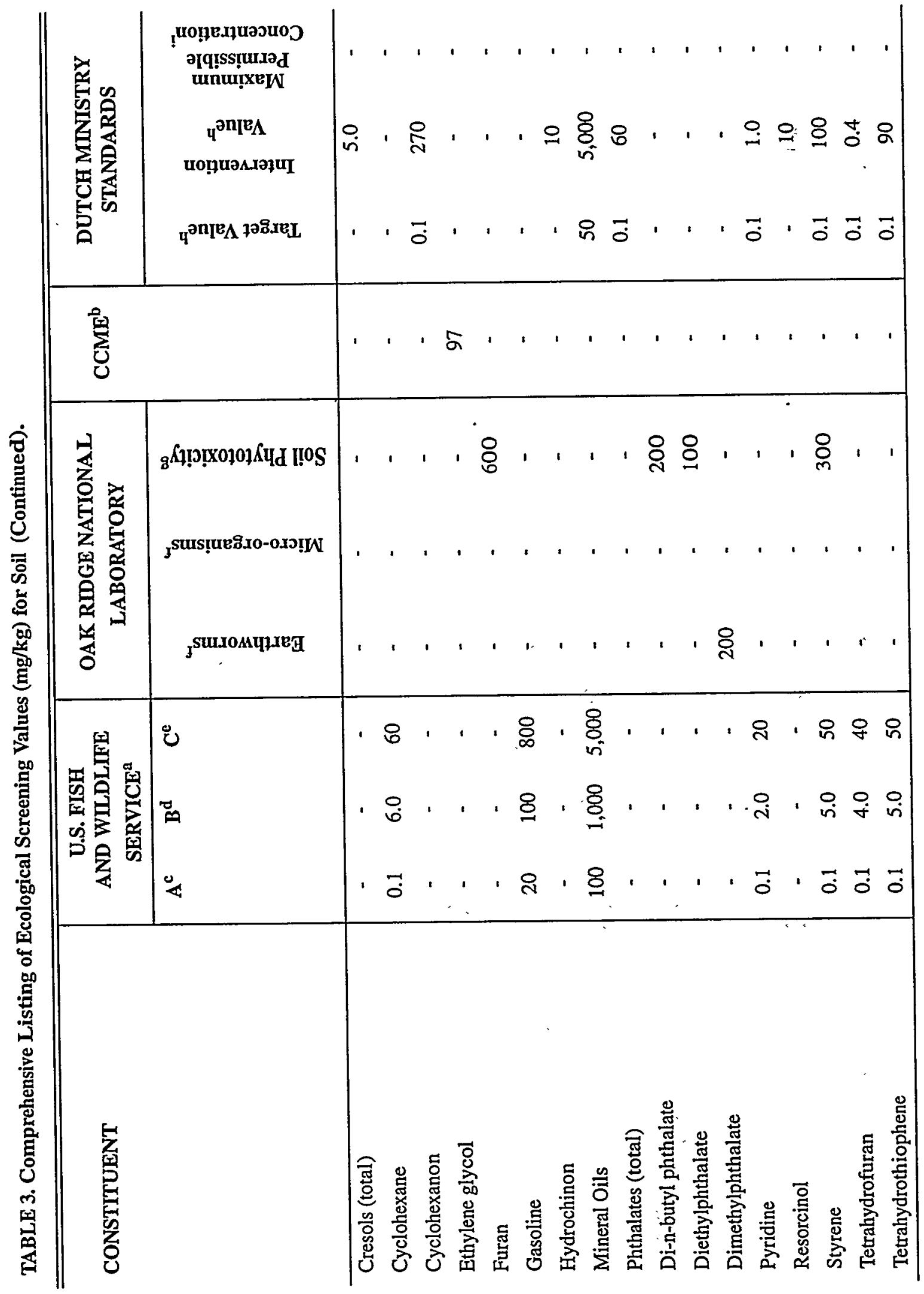




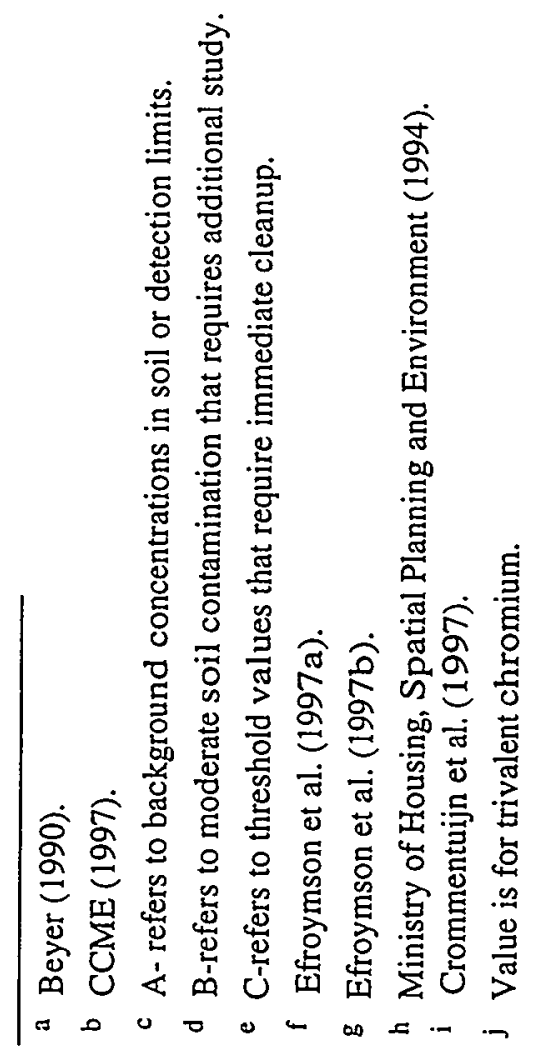


TABLE 4. Ecological Screening Values $(\mu \mathrm{g} / \mathrm{L})$ for Surface Water .

\begin{tabular}{|c|c|c|c|c|c|c|}
\hline CONSTITUENT & & $\begin{array}{c}\text { Target } \\
\text { Analyte List }\end{array}$ & $\begin{array}{c}\text { Target } \\
\text { Compound } \\
\text { List }\end{array}$ & Screening Value & & Source \\
\hline Aluminum & & $\checkmark$ & & 87 & $\therefore$ & [1] \\
\hline Ammonia & & & & 1,000 & & {$[6]$} \\
\hline Antimony & . & $\checkmark$ & & 160 & & {$[1]$} \\
\hline Arsenic III & & $\checkmark$ & & 190 & & {$[1]$} \\
\hline Arsenic V & , & $\checkmark$ & & 3.1 & & [3] \\
\hline Arsenic & & $\checkmark$ & & 5.0 & & {$[5]$} \\
\hline Barium & & $\checkmark$ & & 4.0 & & [3] \\
\hline Beryllium & & $\checkmark$ & & 0.53 & & [1] \\
\hline Boron & & & & 750 & • & [1] \\
\hline Cadmium & & $\checkmark$ & & $0.66^{*}$ & & [1] \\
\hline Calcium & & $\checkmark$ & & 116,000 & & [4] \\
\hline Chromium III & & $\checkmark$ & & $117.32 *$ & & [1] \\
\hline Chromium VI & & $\checkmark$ & & $11^{*}$ & & [1] \\
\hline Cobalt & & $\checkmark$ & & 23 & & [3] \\
\hline Copper & $\therefore$ & $\checkmark$ & & $6.54 *$ & . & [1] \\
\hline Cyanide & & $\checkmark$ & & 5.2 & & [1] \\
\hline Iron & & $\checkmark$ & & 1,000 & & [1] \\
\hline Lead & & $\checkmark$ & & $1.32 *$ & & [1] \\
\hline Lithium & & & & 14 & & ;[3] \\
\hline Magnesium & & $\checkmark$ & & 82,000 & & {$[4]$} \\
\hline Manganese & & $\checkmark$ & & 120 & & [3] \\
\hline Mercury (inorganic) & & $\checkmark$ & & 0.012 & & [1] \\
\hline Mercury (methyl) & $\sim$ & $\checkmark$ & & 0.0028 & & [3] \\
\hline Molybdenum & & & & 370 & & [3] \\
\hline Nickel & . & $\checkmark$ & & $87.71^{*}$ & & [1] \\
\hline Potassium & & $\checkmark$ & & 53,000 & & [4] \\
\hline Selenium & & $\checkmark$ & & 5.0 & & [1] \\
\hline Silver & & $\checkmark$ & & 0.012 & & [1] \\
\hline Sodium & & $\checkmark$ & & 680,000 & & [4] \\
\hline Strontium & & & & 1,500 & & [3] \\
\hline Sulfide(S2-, HS-) & & & & 2.0 & & [1] \\
\hline Thallium & & $\checkmark$ & & 4.0 & & [1] \\
\hline Tin & & & & 73 & & [3] \\
\hline Uranium & & & & 2.6 & & {$[3]$} \\
\hline Vanadium & & $\checkmark$ & & 20 & & [3] \\
\hline
\end{tabular}




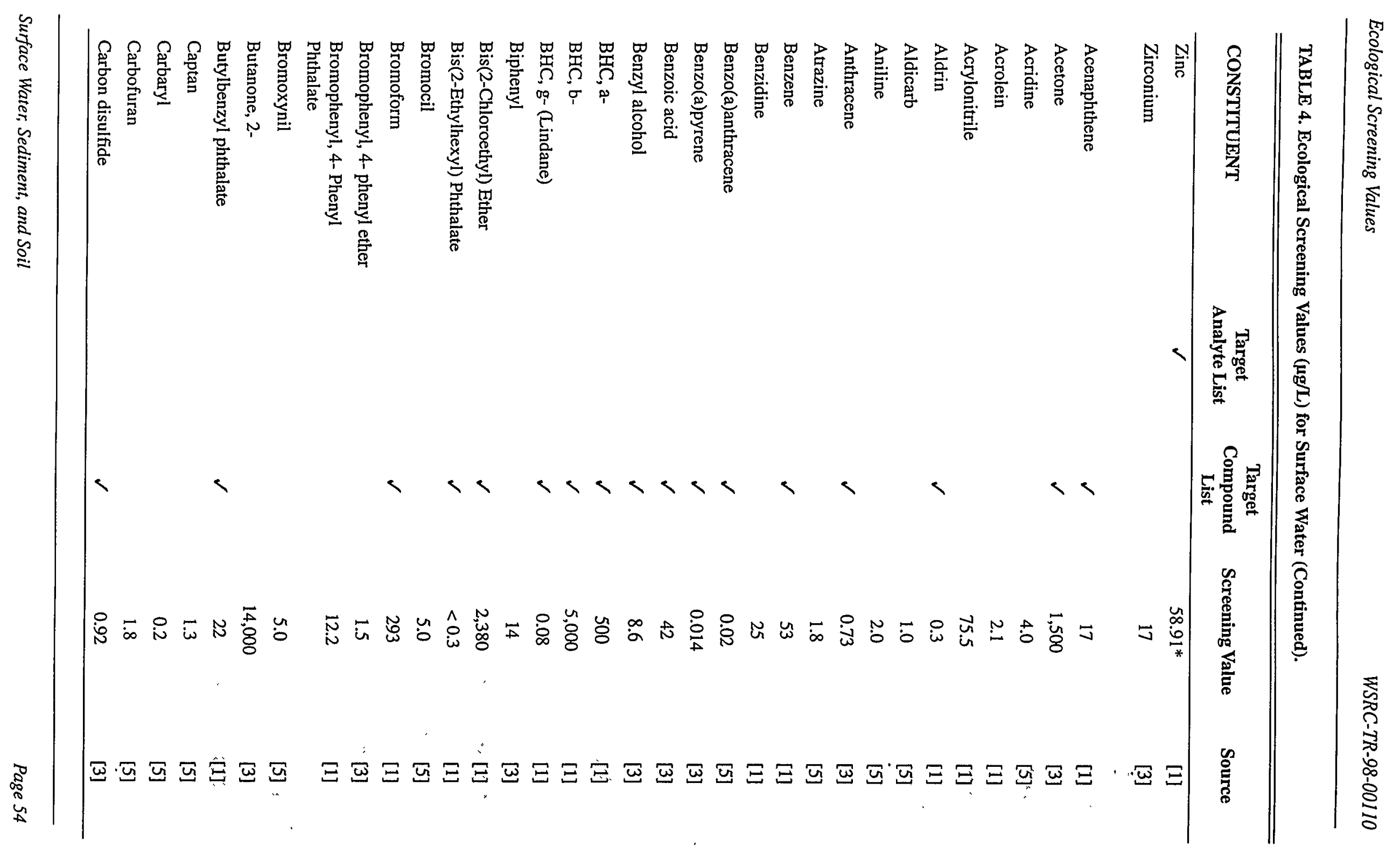


TABLE 4. Ecological Screening Values ( $\mu \mathrm{g} / \mathrm{L})$ for Surface Water (Continued).

\begin{tabular}{|c|c|c|c|c|c|c|}
\hline CONSTITUENT & & $\begin{array}{c}\text { Target } \\
\text { Analyte List }\end{array}$ & $\begin{array}{c}\text { Target } \\
\text { Compound } \\
\text { List }\end{array}$ & Screening Value & & Source \\
\hline Carbon tetrachloride & & & $\checkmark$ & 352 & & [1] \\
\hline Chlordane & & & $\checkmark$ & 0.0043 & . & [1] \\
\hline Chloride & & & & 230,000 & - & [1] \\
\hline Chlorine(Total Residual) & & & & 11 & & [1] \\
\hline Chlorobenzene & & & $\checkmark$ & 195 & & [1] \\
\hline Chloroethylvinyl, 2-Ether & $\therefore$ & $\because$ & & 3,540 & $\therefore$ & [1] \\
\hline Chloroform & & & $\sqrt{ }$ & 289 & & [1] \\
\hline Chlorophenol, $2-\quad, \cdots$ & . & $\therefore$ & $\checkmark$ & 43.8 & $\therefore$ & [1] \\
\hline Chlorophenol, 3-Methyl-4- & & & & 0.3 & & [1] \\
\hline Chloropyrifos & ' & & & 0.041 & & [1] \\
\hline Chlorothalonil & & & & 0.2 & $\cdot$ & [5] \\
\hline Cyazinine & & & & 2.0 & & [5] \\
\hline $\mathrm{DDD}, 4,4^{\prime}-$ & & & $\checkmark$ & 0.0064 & & [1] \\
\hline $\mathrm{DDE}, 4,4^{\prime}-$ & . & . & $\checkmark$ & 10.5 & & {$[1]$} \\
\hline DDT, $4,4^{\prime}-$ & & & $\checkmark$ & 0.001 & & [1] \\
\hline Decane & & & & 49 & & [3] \\
\hline Deltamethrin & & & & 0.0004 & & {$[5]$. } \\
\hline Demeton & & & & 0.1 & & {$[1]$} \\
\hline Diazinon & & & & 0.043 & & {$[3]$} \\
\hline Dibenzofuran & & & $\checkmark$ & 3.7 & & [3] \\
\hline Dicamba & & & & 10 & & [5] \\
\hline Dichlorobenzene, 1,2 & & & $\checkmark$ & 15.8 & . & {$[1]$} \\
\hline Dichlorobenzene, 1,3- & & & $\checkmark$ & 50.2 & & [1] \\
\hline Dichlorobenżene, $1,4-$ & . & : & $\checkmark$ & -11.2 & . & {$[1]$} \\
\hline Dichloroethane, 1,1- & & & $\checkmark$ & 47 & & [3] \\
\hline Dichloroethane, $1,2-$ & $\therefore$ & $\because$ & $\checkmark$ & 2,000 & & {$[1]$} \\
\hline Dichloroethene, 1,1- & & & $\checkmark$ & 303 & & [1] \\
\hline Dichlóroethene, 1,2- & & . & & 590 & & [3] \\
\hline Dichloroethylene, 1,2-trans- & & & $\checkmark$ & 1,350 & & [1] \\
\hline Dichlorophenols & & & & 0.2 & & {$[5]$} \\
\hline Dichlorophenol, 2,4- & & & $\checkmark$ & 36.5 & & [1] \\
\hline Dichloropropane, 1,2- & & & $\checkmark$ & 525 & & {$[1]$} \\
\hline Dichloropropene, 1,3- & & & $\checkmark$ & 0.055 & & [3] \\
\hline $\begin{array}{l}\text { Dichloropropylene, } 1,3-\text { (cis } \\
\text { and trans) }\end{array}$ & & & & 24.4 & & {$[1]$} \\
\hline Diclofop-methyl & & & & 6.1 & - & [5] \\
\hline Dieldrin & & & $\checkmark$ & 0.0019 & & [1] \\
\hline
\end{tabular}


TABLE 4. Ecological Screening Values ( $\mu \mathrm{g} / \mathrm{L})$ for Surface Water (Continued).

\begin{tabular}{|c|c|c|c|c|}
\hline CONSTITUENT & $\begin{array}{c}\text { Target } \\
\text { Analyte List }\end{array}$ & $\begin{array}{c}\text { Target } \\
\text { Compound } \\
\text { List }\end{array}$ & Screening Value & Source \\
\hline Diethyl phthalate & & $\checkmark$ & 521 & [1] \\
\hline Di (2-ethyl hexyl) phthalate & & & 16 & [5] \\
\hline Dimethyl phthalate & & $\checkmark$ & 330 & {$[-1]$} \\
\hline Dimethylphenol, 2,4- & & $\checkmark$ & 21.2 & {$[1]$} \\
\hline Dinitrophenol, 2,4- & & $\checkmark$ & 6.2 & {$[1]$} \\
\hline Dinitrophenol, 2-Methyl-4,6- & & & 2.3 & {$[1]$} \\
\hline Dinitrotoluene, 2,4- & & $\checkmark$ & 310 & [1] \\
\hline Di-n-butyl phthalate & & $\checkmark$ & 9.4 & {$[1]$} \\
\hline Di-n-octyl phthalate & & $\checkmark$ & 708 & {$[4]$} \\
\hline Dioxin, 2,3,7,8-TCDD & & & 0.00001 & {$[1]$} \\
\hline Diphenylhydrazine, 1,2- & & & 2.7 & [1] \\
\hline Endosulfan, a- & & $\checkmark$ & 0.056 & [1] \\
\hline Endosulfan, b- & & $\checkmark$ & 0.056 & {$[1]$} \\
\hline Endrin & & $\checkmark$ & 0.0023 & [1] \\
\hline Ethylbenzene & & $\checkmark$ & 453 & [1] \\
\hline Ethylene Glycol & & & 192,000 & [5] \\
\hline Fluoranthene & & $\checkmark$ & 39.8 & {$[1]$} \\
\hline Fluorene & & $\checkmark$ & 3.9 & {$[2,3]$} \\
\hline Glyphosate & & & 65. & {$[5]$} \\
\hline Guthion & & . & 0.01 & [1] \\
\hline Heptachlor & & & 0.0038 & [1] \\
\hline Heptachlor Epoxide & & $\checkmark$ & 0.0038 & [1] \\
\hline Hexachlorobutadiene & & $\checkmark$ & 0.93 & [1] \\
\hline Hexachlorocyclopentadiene & & $\checkmark$ & 0.07 & [1] \\
\hline Hexachloroethane & & $\checkmark$ & 9.8 & [1] \\
\hline Hexane & & & 0.58 & [3] \\
\hline Hexanone, 2- & & $\checkmark$ & 99 & [3] \\
\hline Isophorone & & $\checkmark$ & 1,170 & [1] \\
\hline Linuron & & & 7.0 & {$[5]$} \\
\hline Malathion & & & 0.1 & [1] \\
\hline Methoxychlor & & $\checkmark$ & 0.03 & [1] \\
\hline $\begin{array}{l}\text { Methyl Bromide (Bro- } \\
\text { momethane) }\end{array}$ & & $\checkmark$ & 110 & [1] \\
\hline $\begin{array}{l}\text { Methyl Chloride (Chlo- } \\
\text { romethane) }\end{array}$ & & $\checkmark$ & 5,500 & {$[1]$} \\
\hline $\begin{array}{l}\text { Methylene Chloride (Dichlo- } \\
\text { romethane) }\end{array}$ & & $\checkmark$ & 1,930 & [1] \\
\hline
\end{tabular}


TABLE 4. Ecological Screening Values ( $\mu \mathrm{g} / \mathrm{L})$ for Surface Water (Continued).

\begin{tabular}{|c|c|c|c|c|}
\hline CONSTITUENT & $\begin{array}{c}\text { Target } \\
\text { Analyte List }\end{array}$ & $\begin{array}{c}\text { Target } \\
\text { Compound } \\
\text { List }\end{array}$ & Screening Value & Source \\
\hline Methylnaphthalene, 1 - & & & 2.1 & [3] \\
\hline Methyl, 4- , 2-pentanone & & & 170 & [3] \\
\hline Methylphenol, 2- & & & 13 & {$[3]$} \\
\hline Metolachlor & & & 7.8 & {$[5]$} \\
\hline Metribuzin & & & 1.0 & {$[5]$} \\
\hline Mirex & & & 0.001 & $-[1]$ \\
\hline Monochlorobenzene & & & 1.3 & {$[5]$} \\
\hline Monochlorophenols & & & 7.0 & {$[5]$} \\
\hline N-Nitrosodiphenylamine & & $\checkmark$ & 58.5 & [1] \\
\hline Naphthalene & & $\checkmark$ & 62 & {$[1]$} \\
\hline Nitrite & & & 60 & {$[5]$} \\
\hline Nitrobenzene & & $\checkmark$ & 270 & {$[1]$} \\
\hline Nitrophenol, 2- & & $\checkmark$ & 3,500 & {$[1]$} \\
\hline Nitrophenol, 4- & & $\checkmark$ & 82.8 & {$[1]$} \\
\hline Octanone, 2- & & & 8.3 & [3] \\
\hline Oil \& Grease & & & 0.01 & {$[1]$} \\
\hline PAH's & & & 0.02 & {$[5]$. } \\
\hline Parathion & & & 0.013 & {$[1]$} \\
\hline PCB-1016 & & $\checkmark$ & 0.014 & {$[1]$} \\
\hline PCB-1221 & & $\checkmark$ & 0.014 & [1] \\
\hline PCB-1232 & & $\checkmark$ & 0.014 & {$[1]$} \\
\hline PCB-1242 & & $\checkmark$ & 0.014 & {$[1]$} \\
\hline PCB-1248 & & $\checkmark$ & 0.014 & {$[1]$} \\
\hline PCB-1254 & & $\checkmark$ & 0.014 & {$[1]$} \\
\hline PCB-1260 & & $\checkmark$ & 0.014 & [1] \\
\hline PCBs total & & $\checkmark$ & 0.14 & {$[3]$} \\
\hline Pentachlorobenzene & & & 50 & {$[1]$} \\
\hline Pentachlorophenol & & $\checkmark$ & 13 & {$[1]$} \\
\hline Pentanol, 1- & & & 110 & {$[3]$} \\
\hline Phenanthrene & & $\checkmark$ & 0.4 & {$[5]$} \\
\hline Phenol & & $\checkmark$ & 256 & [1] \\
\hline Picloram & & & 29 & {$[5]$} \\
\hline Propylene Glycol & & & 192,000 & {$[5]$} \\
\hline Propanol, 2- & & & 7.5 & {$[3]$} \\
\hline Pyrene & & & 0.02 & {$[5]$} \\
\hline Quinoline & & & 3.0 & {$[5]$} \\
\hline Simazine & & & 10 & {$[5]$} \\
\hline
\end{tabular}


TABLE 4. Ecological Screening Values $(\mu g / L)$ for Surface Water (Continued).

\begin{tabular}{|c|c|c|c|c|}
\hline CONSTITUENT & $\begin{array}{c}\text { Target } \\
\text { Analyte List }\end{array}$ & $\begin{array}{c}\text { Target } \\
\text { Compound } \\
\text { List }\end{array}$ & Screening Value & Source \\
\hline Tebuthiuron & & & 1.6 & [5] \\
\hline Tetrachlorobenzene, $1,2,3,4-$ & & & 1.8 & [5] \\
\hline Tetrachlorobenzene, $1,2,4,5$ & & & 50 & [1] \\
\hline Tetrachloroethane, $1,1,2,2-$ & & $\checkmark$ & 240 & [1] \\
\hline Tetrachloroethene & & $\checkmark$ & 84 & [1] \\
\hline Tetrachloromethane & & & 240 & {$[2,3]$} \\
\hline Tetrachlorophenols & & & 1.0 & [5] \\
\hline Toluene & & $\sqrt{ }$ & 175 & {$[1]$} \\
\hline Toxaphene & & $\checkmark$ & 0.0002 & [1] \\
\hline Trialate & & & 0.24 & [5] \\
\hline Tribromomethane & · & & 320 & {$[2,3]$} \\
\hline Tributyltin & & & 0.026 & [1] \\
\hline Trichlorobenzene, 1,2,3- & & & 8.0 & [5] \\
\hline Trichlorobenzene, 1,2,4- & & $\checkmark$ & 44.9 & [1] \\
\hline Trichloroethane, 1,1,1- & & $\checkmark$ & 528 & [1] \\
\hline Trichloroethane, $1,1,2-$ & & $\checkmark$ & 940 & [1] \\
\hline Trichloroethene & & & 47 & [3] \\
\hline Trichlorophenols & & & 18 & [5] \\
\hline Trichlorophenol, 2,4,6- & & $\checkmark$ & 3.2 & [1] \\
\hline Trifuralin & & & 0.1 & [5] \\
\hline Triphenyltin & & & 0.02 & [5] \\
\hline Vinyl Acetate & & $\checkmark$ & 16 & [3] \\
\hline Xylene & & $\checkmark$ & 13 & [3] \\
\hline Xylene, $\mathrm{m}$ - & & $\checkmark$ & 1.8 & {$[2,4]$} \\
\hline
\end{tabular}

*Hardness based on $50 \mathrm{mg} / \mathrm{L} \mathrm{CaCO}$. Adjustments should use the following equations:

\begin{tabular}{|c|c|c|}
\hline Constituent & Acute Screening Value & Chronic Screening Value \\
\hline Cadmium & $\mathrm{e}^{(1.128(\ln \mathrm{H})-3.828)}$ & $\mathrm{e}^{(1.785(\ln H)-3.49)}$ \\
\hline Chromium III & $\mathrm{e}^{(0.819(\ln \mathrm{H})+3.688)}$ & $\mathrm{e}^{(0.819(\ln \mathrm{H})+1.561)}$ \\
\hline Copper & $\mathrm{e}^{(0.9422(\ln \mathrm{H})-1.464)}$ & $\mathrm{e}^{(0.8545(\ln \mathrm{H})-1.465)}$ \\
\hline Lead & $\mathrm{e}^{(1.273(\mathrm{lnH})-1.46)}$ & $\mathrm{e}^{(1.273(\mathrm{lnH})-4.705)}$ \\
\hline Nickel & $\mathrm{e}^{(0.846(\ln \mathrm{H})+3.3612)}$ & $\mathrm{e}^{(0.846(\ln \mathrm{H})+1.1645)}$ \\
\hline Silver & $e^{(1.72(\ln H)-6.52)}$ & \\
\hline Zinc & $e^{(0.8473(\ln H)+8.8604)}$ & $\mathrm{e}^{(0.8473(\ln \mathrm{H})+0.7614}$ \\
\hline
\end{tabular}




\section{Source:}

[1]Chronic Ambient Water Quality Criteria (EPA 1995).

[2]Ecotox Threshold (Tier II) Value (EPA 1996).

[3]Tier II Secondary Chronic Value (Suter and Tsao 1996).

[4]Lowest Chronic Value (Suter and Tsao 1996).

[5]Canadian Water Guidelines (Environment Canada 1998).

[6]Ammonia is $\mathrm{pH}$ and temperature dependent. The proposed value was taken from the 4-day average chronic concentration in water having a temperature of $30^{\circ} \mathrm{C}$ and a $\mathrm{pH}$ of 8.0 when salmonids and other sensitive coldwater species absent (EPA 1985). 
TABLE 5. Ecological Screening Values for Sediment .

\begin{tabular}{|c|c|c|c|c|}
\hline CONSTITUENT & $\begin{array}{c}\text { Target } \\
\text { Analyte List }\end{array}$ & $\begin{array}{c}\text { Target } \\
\text { Compound } \\
\text { List }\end{array}$ & $\begin{array}{l}\text { Screening } \\
\text { Value }\end{array}$ & Source \\
\hline Metals (mg/kg) & & 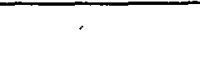 & & \\
\hline Antimony & $\checkmark$ & & 12 & [1] \\
\hline Arsenic & $\checkmark$ & & 7.24 & [1] \\
\hline Arsenic III & $\checkmark$ & & 8.2 & [2] \\
\hline Barium & $\checkmark$ & & 200 & [4] \\
\hline Cadmium & $\checkmark$ & & 1.0 & [1] \\
\hline Chromium & $\checkmark$ & & 52.3 & [1] \\
\hline Cobalt & $\checkmark$ & & 20 & [4] \\
\hline Copper & $\checkmark$ & & 18.7 & {$[1]$} \\
\hline Lead & $\checkmark$ & & 30.2 & [1] \\
\hline Mercury & $\checkmark$ & & 0.13 & [1] \\
\hline Molybdenum & & & 10 & {$[4]$} \\
\hline Nickel & $\checkmark$ & & 15.9 & [1] \\
\hline Silver & $\checkmark$ & & 2.0 & [1] \\
\hline Zinc & $\checkmark$ & & 124 & [1] \\
\hline \multicolumn{5}{|l|}{ Inorganic Compounds (mg/kg) } \\
\hline Cyanide (free) & $\checkmark$ & & 1.0 & [4] \\
\hline Cyanide complex $(\mathrm{pH}<5)$ & $\checkmark$ & & 5.0 & [4] \\
\hline Cyanide complex $(\mathrm{pH}>5)$ & $\checkmark$ & & 5.0 & [4] \\
\hline Thiocyanates (total) & & & $2.0^{*}$ & [4] \\
\hline \multicolumn{5}{|l|}{ Organics ( $\mu \mathrm{g} / \mathrm{kg}$ ) } \\
\hline Acenaphthene & & $\checkmark$ & 330 & [1] \\
\hline Acenaphthylene & & $\checkmark$ & 330 & {$[1]$} \\
\hline Aldrin & & $\checkmark$ & 2.5 & [4] \\
\hline Anthracene & & $\checkmark$ & 330 & [1] \\
\hline Atrazine & & & 0.05 & [4] \\
\hline Benzene & & $\checkmark$ & 50 & {$[4]$} \\
\hline Benzo(a)anthracene & & $\checkmark$ & 330 & {$[1]$} \\
\hline Benzo(a)pyrene & & $\checkmark$ & 330 & {$[1]$} \\
\hline Biphenyl & & & 1,100 & [2] \\
\hline Bis(2-ethylhexyl)phthalate & & $\checkmark$ & 182 & [1] \\
\hline Bromophenyl phenyl ether, 4- & & $\checkmark$ & 1,300 & [2] \\
\hline Butylbenzyl phthalate & & $\checkmark$ & 11,000 & {$[2]$} \\
\hline Carbaryl & & & $500^{*}$ & {$[4]$} \\
\hline Carbofuran & & & $200 *$ & [4] \\
\hline
\end{tabular}


TABLE 5. Ecological Screening Values for Sediment .

\begin{tabular}{|c|c|c|c|c|}
\hline CONSTITUENT & $\begin{array}{c}\text { Target } \\
\text { Analyte List }\end{array}$ & $\begin{array}{c}\text { Target } \\
\text { Compound } \\
\text { List }\end{array}$ & $\begin{array}{l}\text { Screening } \\
\text { Value }\end{array}$ & Source \\
\hline Catechol & & & $2,000 *$ & [4] \\
\hline Chlordane & & $\checkmark$ & 1.7 & [1] \\
\hline Chlorobenzene & & $\checkmark$ & 820 & [2] \\
\hline Chloronaphthalene & & & $1,000^{*}$ & [4] \\
\hline Chlorophenols (total) & & $\checkmark$ & $1,000^{*}$ & [4] \\
\hline Chrysiene & & $\checkmark$ & 330 & [1] \\
\hline Cresols (total) & & $\checkmark$ & $500^{*}$ & [4] \\
\hline Cyclohexanon & & & 100 & [4] \\
\hline DDD, p,p'- & & $\checkmark$ & 3.3 & {$[1]$} \\
\hline DDD & & $\checkmark$ & 3.3 & [1] \\
\hline DDE, p,p'- & & $\checkmark$ & 3.3 & [1] \\
\hline DDE & & $\checkmark$ & 3.3 & [1] \\
\hline DDT, p,p' - & & $\checkmark$ & 3.3 & [1] \\
\hline DDT & & $\checkmark$ & 3.3 & [1] \\
\hline DDT (total) & & $\checkmark$ & 3.3 & [1] \\
\hline DDT/DDE/DDD (total) & & $\checkmark$ & 2.5 & {$[4]$} \\
\hline Diazinon & & & 1.9 & [2] \\
\hline Dibenzo(a,h)anthracene & & $\checkmark$ & 330 & {$[1]$} \\
\hline Dibenzofuran & & $\checkmark$ & 2,000 & {$[2]$} \\
\hline Dichlorobenzene, 1,2- & & $\checkmark$ & 340 & {$[2]$} \\
\hline Dichlorobenzene, 1,3- & & $\checkmark$ & 1,700 & {$[2]$} \\
\hline Dichlorobenzene, 1,4- & & $\checkmark$ & 350 & [2] \\
\hline Dichlorobenzene (total) & & $\checkmark$ & 10 & [4] \\
\hline Dichloroethane, 1,2- & & $\checkmark$ & $400 *$ & {$[4]$} \\
\hline Dichloromethane (Methylene Chloride) & & $\checkmark$ & $2,000 *$ & [4] \\
\hline Dichlorophenols (total) & & $\checkmark$ & 3.0 & [4] \\
\hline Dieldrin & & $\checkmark$ & 3.3 & [1] \\
\hline Diethyl phthalate & & $\checkmark$ & 630 & {$[2]$} \\
\hline Di-n-butyl phthalate & & $\checkmark$ & 11,000 & [2] \\
\hline Endosulfan, mixed isomers & & $\checkmark$ & 5.4 & {$[2]$} \\
\hline Endosulfan, alpha & & $\checkmark$ & 2.9 & {$[2]$} \\
\hline Endosulfan, beta & & $\checkmark$ & 14 & {$[2]$} \\
\hline Endrin & & $\checkmark$ & 3.3 & [1] \\
\hline Ethylbenzene & & $\checkmark$ & 50 & [4] \\
\hline Fluoranthene & & $\checkmark$ & 330 & [1] \\
\hline Fluorene & & $\checkmark$ & 330 & [1] \\
\hline $\mathrm{a}-\mathrm{HCH}$ & & & 2.5 & [4] \\
\hline
\end{tabular}


TABLE 5. Ecological Screening Values for Sediment .

\begin{tabular}{|c|c|c|c|c|}
\hline CONSTITUENT & $\begin{array}{c}\text { Target } \\
\text { Analyte List }\end{array}$ & $\begin{array}{c}\text { Target } \\
\text { Compound } \\
\text { List }\end{array}$ & $\begin{array}{l}\text { Screening } \\
\text { Value }\end{array}$ & Source \\
\hline b-HCH & & & 1.0 & [4] \\
\hline $\mathrm{g}-\mathrm{HCH}$ (Lindane) & & $\checkmark$ & 3.3 & [1] \\
\hline Heptachlor Epoxide & & $\checkmark$ & 0.6 & [3] \\
\hline Hexachlorobenzene & & $\checkmark$ & 2.5 & [4] \\
\hline Hexachloroethane & & $\checkmark$ & 1,000 & [2] \\
\hline Hydrochinon & & & $1,000 *$ & [4] \\
\hline Malathion & & & 0.67 & [2] \\
\hline Maneb & & & $3,500 *$ & [4] \\
\hline Methylnaphthalene, 2- & & $\checkmark$ & 330 & [1] \\
\hline Methoxychlor & & $\checkmark$ & 19 & [2] \\
\hline Mineral Oil & & & 50,000 & {$[4]$} \\
\hline Monochlorophenols (total) & & & 2.5 & {$[4]$} \\
\hline Naphthalene & & $\checkmark$ & 330 & [1] \\
\hline PCB (Aroclor 1221) & & $\checkmark$ & 67 & [1] \\
\hline PCB (Aroclor 1254) & & $\checkmark$ & 60 & [3] \\
\hline PCBs (Total) & & $\checkmark$ & 33 & {$[1]$} \\
\hline Pentachlorobenzene & & & 2.5 & [4]. \\
\hline Pentachlorophenol & & $\checkmark$ & 2.0 & [4] \\
\hline Phenanthrene & & $\checkmark$ & 330 & {$[1]$} \\
\hline Phenol & & $\checkmark$ & 50 & [4] \\
\hline \multicolumn{5}{|c|}{ Polycyclic Aromatic Hydrocarbons } \\
\hline Low Molecular Weight & & & 330 & {$[1]$} \\
\hline High Molecular Weight & & & 655 & [i] \\
\hline Total PAHs & & & 1,684 & [1] \\
\hline Pyrene & & $\checkmark$ & 330 & {$[1]$} \\
\hline Pyridine & & & 100 & [4] \\
\hline Resorcinol & & & $1,000^{*}$ & [4] \\
\hline Styrene & & $\checkmark$ & 100 & [4] \\
\hline Tetrachlorobenzenes (total) & & & 10 & [4] \\
\hline Tetrachloroethane, 1,1,2,2- & & $\checkmark$ & 940 & [2] \\
\hline Tetrachloroethene & & $\checkmark$ & 10 & [4] \\
\hline Tetrachloromethane & & & 1.0 & [4] \\
\hline Tetrachlorophenols (total) & & & 1.0 & {$[4]$} \\
\hline Tetrahydrofuran & & & 100 & [4] \\
\hline Tetrahydrothiophene & & & 100 & [4] \\
\hline Toluene & & $\checkmark$ & 50 & [4] \\
\hline Toxaphene & & $\checkmark$ & 28 & [2] \\
\hline
\end{tabular}


TABLE 5. Ecological Screening Values for Sediment .

\begin{tabular}{lcccc}
\hline \hline CONSTITUENT & $\begin{array}{c}\text { Target } \\
\text { Analyte List }\end{array}$ & $\begin{array}{c}\text { Target } \\
\text { Compound } \\
\text { List }\end{array}$ & $\begin{array}{c}\text { Screening } \\
\text { Value }\end{array}$ & Source \\
\hline Tribromomethane & & 650 & {$[2]$} \\
Trichlorobenzene, 1,2,4- & & 9,200 & {$[2]$} \\
Trichlorobenzene (total) & & 10 & {$[4]$} \\
Trichloroethane, 1,1,1- & $\checkmark$ & 170 & {$[2]$.} \\
Trichloroethene & & 1.0 & {$[4]$} \\
Trichloromethane & & $\checkmark$ & 1.0 & {$[4]$} \\
Trichlorophenols (total) & $\checkmark$ & $10^{*}$ & {$[4]$} \\
Vinyl Chloride & & $\checkmark$ & 50 & {$[4]$} \\
Xylene & $\checkmark$ & 25 & {$[2]$} \\
Xylene, m- & & & {$[4]$} \\
\hline
\end{tabular}

* Value represents the intervention value (MHSPE 1994) divided by a factor of 10 .

\section{Source:}

[1]EPA (1995).

[2]EPA (1996).

[3]Environment Canada (1995b).

[4]Ministry of Housing, Spatial Planning and Environment (1994). 
TABLE 6. Recommended Ecological Screening Values ( $\mathrm{mg} / \mathrm{kg}$ ) for Soil .

\begin{tabular}{|c|c|c|c|c|}
\hline CONSTITUENT & $\begin{array}{c}\text { Target } \\
\text { Analyte } \\
\text { List }\end{array}$ & $\begin{array}{c}\text { Target } \\
\text { Compound } \\
\text { List }\end{array}$ & $\begin{array}{l}\text { Screening } \\
\text { Value }\end{array}$ & Source \\
\hline \multicolumn{5}{|l|}{ Inorganics } \\
\hline Aluminum & $\checkmark$ & & 50 & {$[2]$} \\
\hline Antimony & $\checkmark$ & & 3.5 & [5] \\
\hline Arsenic & $\checkmark$ & & 10 & [2] \\
\hline Barium & $\checkmark$ & & 165 & [5] \\
\hline Beryllium & $\checkmark$ & & 1.1 & {$[5]$} \\
\hline Boron & & & 0.5 & {$[2]$} \\
\hline Cadmium & $\checkmark$ & & 1.6 & {$[5]$} \\
\hline Chromium & $\checkmark$ & & .0 .4 & {$[2 ; 3]$} \\
\hline Cobalt & $\checkmark$ & & 20 & {$[1,2,4]$} \\
\hline Copper & $\checkmark$ & & 40 & [5] \\
\hline Iron & $\checkmark$ & & 200 & [2] \\
\hline Lanathum & & & 50 & {$[2]$} \\
\hline Lead & $\checkmark$ & & 50 & {$[1,2]$} \\
\hline Lithium & & & 2.0 & {$[2]$} \\
\hline Manganese & $\checkmark$ & & 100 & [2] \\
\hline Mercury (inorganic) & $\checkmark$ & & 0.1 & [2] \\
\hline Mercury (methyl) & $\checkmark$ & & 0.67 & {$[5]$} \\
\hline Molybdenưm & & & 2.0 & [2] \\
\hline Nickel & $\checkmark$ & & 30 & [2] \\
\hline Selenium & $\checkmark$ & & 0.81 & [5] \\
\hline Silver & $\checkmark$ & & 2.0 & {$[2]$} \\
\hline Technetium & & & 0.2 & [2] \\
\hline Thallium & & & 1.0 & {$[2]$} \\
\hline $\operatorname{Tin}$ & . & & 53 & [5] \\
\hline Titanium & & & 1,000 & {$[2]$} \\
\hline Tungsten & & & 400 & [2] \\
\hline Uranium & & & 5.0 & {$[2]$} \\
\hline Vanadium & $\checkmark$ & & 2.0 & [2] \\
\hline Zinc & $\checkmark$ & & 50 & [2] \\
\hline \multicolumn{5}{|l|}{ Mineral Pollutants } \\
\hline Bromine & & & 10 & [2] \\
\hline Cyanide, free (total) & $\checkmark$ & & 0.9 & [3] \\
\hline Cyanide, comlex (total) & $\checkmark$ & & 5.0 & {$[1]$} \\
\hline Thiocyanates & & & 20 & {$[4]$} \\
\hline
\end{tabular}


TABLE 6. Recommended Ecological Screening Values (mg/kg) for Soil (Continued).

\begin{tabular}{|c|c|c|c|c|}
\hline CONSTITUENT & $\begin{array}{c}\text { Target } \\
\text { Analyte } \\
\text { List }\end{array}$ & $\begin{array}{c}\text { Target } \\
\text { Compound } \\
\text { List }\end{array}$ & $\begin{array}{l}\text { Screening } \\
\text { Value }\end{array}$ & Source \\
\hline Fluorene & & & 30 & [2] \\
\hline Iodine & & & 4.0 & [2] \\
\hline Sulfur & & & 2.0 & [1] \\
\hline \multicolumn{5}{|c|}{ Monocyclic Aromatic Hydrocarbons } \\
\hline Benzene & & $\checkmark$ & 0.05 & [4] \\
\hline Biphenyl & & & 60 & [2] \\
\hline Ethylbenzene & & $\checkmark$ & 0.05 & {$[1,4]$} \\
\hline Toluene & & $\checkmark$ & 0.05 & {$[1,4]$} \\
\hline Trichloroethylene & & $\checkmark$ & 0.001 & [4] \\
\hline Xylene & & $\checkmark$ & 0.05 & {$[1,4]$} \\
\hline Total MAH's & & & 0.1 & [1] \\
\hline \multicolumn{5}{|l|}{ Phenolic Compounds } \\
\hline Phenol & & $\checkmark$ & 0.05 & [4] \\
\hline Chlorophenol, 3- & & & 7.0 & [2] \\
\hline Chlorophenols (each) & & $\checkmark$ & 0.01 & [1] \\
\hline Chlorophenols (total) & & $\checkmark$ & 0.01 & [1] \\
\hline Dichlorophenol, 3,4- & & & 20 & {$[2]$} \\
\hline Dichlorophenols (total) & & & 0.003 & [4] \\
\hline Dinitrophenol, 2,4- & $\checkmark$ & & 20 & [2] \\
\hline Mónochlorophenols (total) & - & & 0.0025 & [4] \\
\hline Nitrophenol, 4- & & $\checkmark$ & 7.0 & [2] \\
\hline Pentachlorophénól & & $\checkmark$ & 0.002 & [4] \\
\hline Tetrachlorophenol, 2,3,4,5- & & & 20 & [2] \\
\hline Tetrachlorophenóls (total) & & & 0.001 & [4] \\
\hline Trichlorophenol, 2,4,5- & $\checkmark$ & & 4.0 & [2] \\
\hline Trichlorophenol, $2,4,6-$ & & & $10^{\circ}$ & [2] \\
\hline Trichlorophenols (total) & & & 0.001 & [4] \\
\hline \multicolumn{5}{|c|}{ Polycyclic Aromatic Hydrocarbons } \\
\hline Acenapthene & & $\checkmark$ & 20 & [2] \\
\hline Anthracene & & $\checkmark$ & 0.1 & {$[.1]$} \\
\hline Benzo(a)pyrene & & $\checkmark$ & 0.1 & [1] \\
\hline Chloronaphthalene & & $\checkmark$ & 1.0 & [4] \\
\hline Fluoranthene & & $\checkmark$ & 0.1 & [1] \\
\hline Naphthalene & & $\checkmark$ & 0.1 & [1] \\
\hline Phenanthrene & & $\checkmark$ & 0.1 & [1] \\
\hline Pyrene & & $\checkmark$ & 0.1 & [1] \\
\hline Total PAH's & & & 1.0 & {$[1,4]$} \\
\hline
\end{tabular}


TABLE 6. Recommended Ecological Screening Values (mg/kg) for Soil (Continued).

\begin{tabular}{|c|c|c|c|c|}
\hline CONSTITUENT & $\begin{array}{c}\text { Target } \\
\text { Analyte } \\
\text { List }\end{array}$ & $\begin{array}{c}\text { Target } \\
\text { Compound } \\
\text { List }\end{array}$ & $\begin{array}{l}\text { Screening } \\
\text { Value }\end{array}$ & Source \\
\hline \multicolumn{5}{|l|}{ Chlorinated Hydrocarbons } \\
\hline Aliphatic chlorinated hydrocarbons (each) & & & 0.1 & [1] \\
\hline Aliphatic chlorinated hydrocarbons (total) & & & 0.1 & [1] \\
\hline Carbon tetrachloride & & $\checkmark$ & 1,000 & [2] \\
\hline Chlorinated hydrocarbons (total) & & & 0.1 & [1] \\
\hline Chloroacetamide & & & 2.0 & {$[2]$} \\
\hline Chloroaniline, 3 - & & & 20 & [2] \\
\hline Chlorobenzene (each) & & $\checkmark$ & 0.05 & [1] \\
\hline Chlorobenzene (total) & & $\checkmark$ & 0.05 & {$[1]$} \\
\hline Cis-1,4-dichloro-2-butene & & & 1,000 & {$[2]$} \\
\hline Dichloroaniline, 2,4- & & & 100 & [2], \\
\hline Dichloroaniline, 3,4- & & & 20 & {$[2]$} \\
\hline Dichlorobenzene & & & 0.01 & [4] \\
\hline Dichloroethane, 1,2- & & $\checkmark$ & 0.4 & [4] \\
\hline Dichloromethane & & $\checkmark$ & 2.0 & [4] \\
\hline Dichloropropane, 1,2- & & & 700 & {$[2]$} \\
\hline Hexachlorobenzene & & $\checkmark$ & 0.0025 & [4] \\
\hline Hexachlorocyclopentadiene & & $\checkmark$ & 10 & [2] \\
\hline Nitrobenzene & & $\checkmark$ & 40 & [2] \\
\hline Nitrosodiphenylamine, $\mathrm{N}$ - & & $\checkmark$ & 20 & [2] \\
\hline Pentachloroaniline & & & 100 & [2] \\
\hline Pentachlorobenzene & & & 0.0025 & [4] \\
\hline PCBs (total) & & $\checkmark$ & 0.02 & [4] \\
\hline Polycyclic chlorinated hydrocarbons (total) & & & 0.1 & [1] \\
\hline Tetrachloroaniline, 2,3,5,6- & & & 20 & $\cdot[2]$ \\
\hline Tetrachlorobenzene & & & 0.01 & [4] \\
\hline Tetrachloroethene & & & 0.01 & [4] \\
\hline Tetrachloromethane & & & 0.001 & [4] \\
\hline Trans-1,4-dichloro-2-butene & & & 1,000 & [2] \\
\hline Trichloroaniline, 2,4,5- & & & 20 & [2] \\
\hline Trichlorobenzene & & $\checkmark$ & 0.01 & [4] \\
\hline Trichloromethane (chloroform) & & & 0.001 & [4] \\
\hline Vinyl chloride & & $\checkmark$ & 0.01 & [4] \\
\hline \multicolumn{5}{|l|}{ Pesticides } \\
\hline Aldrin & & $\checkmark$ & 0.0025 & [4] \\
\hline Atrazine & & & 0.00005 & [4] \\
\hline DDT/DDE/DDD (total) & & $\checkmark$ & 0.0025 & $\cdot \quad[4]$ \\
\hline
\end{tabular}


TABLE 6. Recommended Ecological Screening Values (mg/kg) for Soil (Continued).

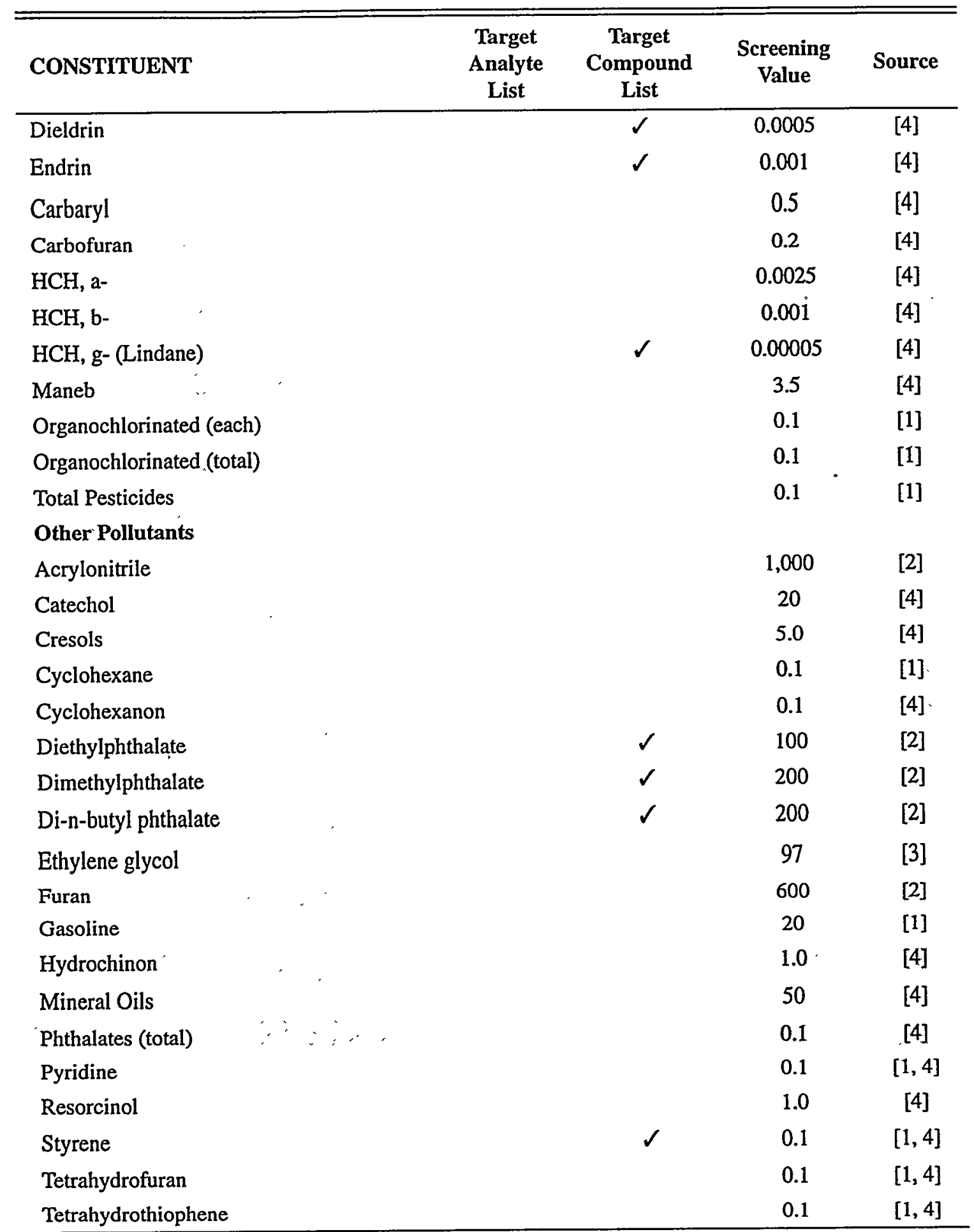

Source:

[1]Beyer (1990).

[2]Oak Ridge National Laboratory (Efroymson et al. 1997a,b).

[3]CCME (1997).

[4]Ministry of Housing, Spatial Planning and Environment (1994).

[5]Crommentuijn et al. (1997). 